\title{
Materieelrechtelijke aspecten van mensenhandel in het Nederlands strafrecht
}

\author{
Marnix Alink en Just Wiarda
}

\section{Inleiding}

In deze tijd van globalisering is de internationale handel in omvang, diversiteit en intensiteit ongekend toegenomen. Helaas brengt dit ook ongeoorloofde vormen van handel teweeg, zoals mensenhandel. Volgens een recent gepubliceerd persbericht van de Verenigde Naties zijn thans wereldwijd meer dan 2,4 miljoen mensen het slachtoffer van mensenhandel, in de seksindustrie of daarbuiten. Het persbericht begeleidde de publicatie van een rapport van de United Nations Office on Drugs and Crime over mensenhandel ten behoeve van de seksindustrie in Europa. ${ }^{2}$ Dat rapport somt voor Europa de kale feiten op: de omvang van de markt wordt gevormd door ongeveer I40.000 slachtoffers, die samen een waarde van circa drie miljard dollar vertegenwoordigen. De uitbuiting van mensen in andere sectoren dan de seksindustrie nog buiten beschouwing gelaten. De mens verworden tot handelswaar, uitgedrukt in geldswaarde. De handel in mensen floreert in de informele economie. Het rapport geeft op treffende wijze de essentie en ernst van mensenhandel weer. Een vorm van slavernij, gestoken in een modern jasje. Het behoeft geen betoog dat achter de cijfers een wereld van leed en ellende schuilgaat. ${ }^{3}$

Nederland wordt in voormeld rapport genoemd als een land van bestemming. Slachtoffers worden naar Nederland verhandeld en alhier uitgebuit. Die rol krijgt Nederland ook toebedeeld in het laatste zogenoemde Trafficking in persons report. Dat is het jaarlijkse landenrapport van het ministerie van Buitenlandse Zaken van de Verenigde Staten over de staat en ontwikkeling van het verschijnsel mensenhandel.4

I Marnix Alink is werkzaam bij de sector straf- en sanctierecht van de Directie Wetgeving van het ministerie van Justitie. Just Wiarda is daar werkzaam geweest. Zij hebben beiden bemoeienis (gehad) met (internationale) strafrechtelijke wetgeving inzake mensenhandel. Zij hebben ernaar gestreefd kritisch en met distantie naar deze wetgeving te kijken. Het preadvies is op persoonlijke titel geschreven.

2 Zie www.unodc.org/documents/publications/TiP_Europe_EN_LORES.pdf.

3 Voor een recente beschrijving en een schrijnend relaas van het verschijnsel mensenhandel zie E. Benjamin Skinner, 'Mensenhandel op klaarlichte dag', Cossee, 2010.

4 De beoordeling van Nederland is te raadplegen via www.state.gov/documents/organization/I43188.pdf. Nederland staat er overigens relatief goed op en is opnieuw ingedeeld in de hoogste ranking 'tier I'. 
Daarin wordt ook vermeld dat Nederland bronland van mensenhandel is: ook in Nederland worden mensen slachtoffer van mensenhandel. Van dat gegeven was Nederland al langer doordrongen door onder andere de rapportages van de Nationaal Rapporteur Mensenhandel. ${ }^{5}$

Blijkens de publieke en politieke aandacht, zowel internationaal als nationaal, voor de aanpak van mensenhandel is het verschijnsel nog onverminderd actueel. Dat geldt zowel voor de strafwetgeving inzake mensenhandel als de toepassing van deze wetgeving in de praktijk. Ter illustratie kan worden gewezen op de in het kader van de Europese Unie lopende onderhandelingen over een nieuwe richtlijn ter bestrijding van mensenhandel en op de ruime media-aandacht voor een recente strafrechtelijke veroordeling inzake overige uitbuiting. ${ }^{6}$ De strafwetgeving inzake mensenhandel is dezer dagen geen rustig bezit, maar volop in beweging.

Mensenhandel is strafbaar gesteld in artikel $273 \mathrm{f}$ van het Wetboek van Strafrecht (Sr). Mensenhandel is (gericht op) uitbuiting van mensen in arbeid en dienstverlening. Mensenhandel houdt volgens gangbare opvattingen een (ernstige) schending van fundamentele mensenrechten en van de menselijke waardigheid in en maakt inbreuk op de vrijheid van mensen.7 Mensenhandel bevat grof gezegd twee hoofdelementen: onvrijwilligheid en uitbuiting. Die twee elementen hangen samen. In de regel laat iemand zich niet uit vrije wil uitbuiten. Iemand die 'instemt' met uitbuiting doet dat, omdat hij zich in een kwetsbare positie bevindt en geen andere kant op kan.

Volgens Van Dale betekent uitbuiten: iemand tegen ongunstige condities laten werken om er zo veel mogelijk aan te verdienen.

Mensenhandel is moderne slavernij en gedijt in armoede, in een wereld waarin zeer grote sociale en economische verschillen bestaan. Deze ongelijkheid genereert migratiestromen op zoek naar arbeid en inkomen, tegen condities en onder omstandigheden die in het land van bestemming ongebruikelijk of zelfs onaanvaardbaar zijn. De slachtoffers bevinden zich in een marginale positie op de arbeidsmarkt. Mensenhandel kan evenwel ook een lokale aangelegenheid zijn.

Mensenhandel kent vele verschijningsvormen: criminele organisaties die mensen laten werken of kleinschalige criminaliteit, zoals de loverboy ${ }^{8}$ of souteneur die zijn 'vriendin' dwingt zich te prostitueren. Mensenhandel speelt zich af in de

5 Voor een brede, actuele en rijke achtergrondstudie van mensenhandel zij allereerst verwezen naar Nationaal Rapporteur Mensenhandel (2009), 'Mensenhandel - Zevende rapportage van de Nationaal Rapporteur', Den Haag: BNRM (hierna te noemen NRM 7).

6 'Hoge straf voor uitbuiting kroepoekbakkers', www.nrc.nl/binnenland/article2537731.ece/ Hoge_straf_voor_uitbuiting_kroepoekbakkers.

7 Zie bijvoorbeeld M. Boot-Matthijssen, 'Mensenhandel en mensenrechten', Internationale Spectator, jaargang 62, nr. I2, december 2008, p. 668.

8 Sinds enige tijd is de term 'pooierboy' in zwang (zie Aanhangsel Handelingen, vergaderjaar 2008/09, nr. 86r en I424). Die term is geen verrijking van de Nederlandse taal, al is het oogmerk om de figuur loverboy te ontdoen van een liefdevolle connotatie en de ware aard van deze 'boy' tot uitdrukking te brengen, sympathiek. 
risicosectoren van de samenleving, zoals de seksindustrie ${ }^{9}$, land- en tuinbouw, horeca, huishouding, uitzendbranche en andere takken van bedrijvigheid die draaien op goedkope arbeidskrachten. In Nederland doet mensenhandel zich overwegend voor in de legale dienstverlening. ${ }^{\text {10 }}$ Maar mensenhandel komt ook voor in criminaliteit of kan verweven zijn met vormen van criminaliteit.

Het verschijnsel mensenhandel heeft vele facetten. Dat geldt ook voor de internationale en nationale aanpak ervan. Die aanpak is alomvattend, en speelt zich af op de terreinen van preventie, bestrijding, internationale (strafrechtelijke) samenwerking en bijstand aan slachtoffers en hun familie. Hierbij werken overheden en niet-overheden samen. De strafrechtelijke bestrijding van mensenhandel is een bescheiden, gewichtig en noodzakelijk sluitstuk in die aanpak. Bij de strafbaarstelling van mensenhandel staat het belang van het individu voorop. Deze voorziet in de strafrechtelijke bescherming van arbeiders en dienstverleners tegen aantasting van hun lichamelijke en geestelijke integriteit en inbreuken op hun persoonlijke vrijheid.

Er is de afgelopen jaren in de rechtsgeleerde literatuur en daarbuiten veel gepubliceerd over de verschillende facetten van het verschijnsel mensenhandel en de aanpak daarvan. In Nederland vormen eerst en vooral de rapportages van de Nationaal Rapporteur Mensenhandel een veelomvattende en rijke bron. Uitvoerig worden daarin ontwikkelingen in wetgeving, praktijk en jurisprudentie beschreven. De zevende rapportage - de tot nu toe laatste en dikste in de reeks - spant daarbij de kroon. Het is met recht een standaardwerk op dit terrein.

Ook de rechtspraktijk heeft zich niet onbetuigd gelaten. $\mathrm{Zij}$ is zoekende geweest en heeft geworsteld met de toepassing van de strafbaarstelling van mensenhandel, in het bijzonder op het nieuwe terrein van de zogenoemde overige uitbuiting. Niet voor niets heeft de Nationaal Rapporteur Mensenhandel de aanbeveling gedaan om te voorzien in specialisatie binnen de rechterlijke macht. Ook in het eerder genoemde Trafficking in persons report wordt aanbevolen om de bewustwording bij de rechterlijke macht inzake mensenhandel verder te versterken.

Het is goed om de strekking van artikel $273 \mathrm{f} \mathrm{Sr}$ bij de bepaling van zijn beschermingsomvang in het oog te houden. De rechtspraak lijkt dit steeds meer te doen. De Hoge Raad en advocaat-generaal Knigge hebben in oktober 2009 rechtspraktijk en wetenschap verrijkt met een richtinggevende uitspraak en conclusie. ${ }^{\text {II }}$

9 Zie nader over prostitutie in een aantal landen de recente serie 'prostitutie wereldwijd' in NRC Handelsblad (juni-september 20I0).

Io Sinds I oktober 2000 is uitbating van vrijwillige prostitutie door personen vanaf I8 jaar niet langer strafbaar in Nederland. In hoofdstuk 6.2 wordt gewag gemaakt van het voornemen om de leeftijdsgrens voor uitbating van prostitutie en registratie van prostituees te stellen op 2I jaar.

II HR 27 oktober 2009, LJN: BI7099, zaak 08/03895, nog te verschijnen in de NJ m.nt. Buruma. Zie hoofdstuk 4.3.2. 
Over mensenhandel valt dus zeer veel te zeggen, vanuit verschillend maatschappelijk en wetenschappelijk perspectief. Dit preadvies concentreert zich op de materieelrechtelijke aspecten van mensenhandel. Dat betekent dat veel belangwekkends onbesproken moet blijven, zoals handhaving, de positie van het slachtoffer in de strafzaak, internationale samenwerking of de bijstand aan en bescherming van (illegale) slachtoffers.

Het preadvies behandelt de strekking en reikwijdte van de strafbaarstelling van mensenhandel in artikel $273 \mathrm{f} \mathrm{Sr}$. Dat artikel beoogt mensenhandel in al zijn vormen strafbaar te stellen. Doel van onze exercitie is om onder meer na te gaan of de wetgever daarin ten volle en op de goede wijze is geslaagd.

Voor een goed begrip van de huidige strafbaarstelling van mensenhandel in artikel $273 \mathrm{f} \mathrm{Sr}$ is kennis van haar ontstaanswijze, wetsgeschiedenis en verdragsrechtelijke achtergrond zinvol. Die worden besproken in hoofdstuk 2. In hoofdstuk 3 volgt een beschrijving van de voor mensenhandel relevante jurisprudentie van het Europees Hof voor de rechten van de mens. Hoofdstuk 4 bevat een analyse van de strafbaarstelling van mensenhandel in artikel $273 \mathrm{f} \mathrm{Sr}$. Daarin hopen we door te dringen tot de materieelrechtelijke kern van de bepaling. Bijzondere aandacht gaat daarbij uit naar het hiervoor vermelde arrest van de Hoge Raad en de bijbehorende conclusie. In hoofdstuk 5 worden enkele aan de strafbaarstelling verwante aspecten uiteengezet. Hoofdstuk 6 gaat in op aanpalende wet- en regelgeving. Daarin wordt ook aandacht besteed aan de beoogde nieuwe prostitutiewetgeving. We besluiten met een aantal conclusies in hoofdstuk 7 .

Dit preadvies is vanzelfsprekend in de eerste plaats en vooral geschreven ten behoeve van de vergadering van de afdeling Strafrecht van de Vereniging voor de vergelijkende studie van het recht van België en Nederland. Naar wij hopen vormt het vanuit het oogpunt van rechtsvergelijking bouwstenen voor een vruchtbare en boeiende discussie met de Belgische sectie. Ook hopen wij dat dit preadvies als een leidraad voor de rechtspraktijk kan dienen. Die wens heeft mede de gekozen opzet en inkadering bepaald.

\section{De ontwikkeling van de strafbaarstelling van mensenhandel}

\section{I Wetsgeschiedenis}

\subsubsection{Inleiding}

Hier volgt een beschrijving op hoofdlijnen van de ontstaanswijze, wetsgeschiedenis en verdragsrechtelijke achtergrond van artikel $273 \mathrm{f} \mathrm{Sr}$. Vormgeving, reikwijdte en strekking zijn aan verschillende wijzigingen en internationale invloed onderhevig geweest. Voor de uitleg van de huidige strafbaarstelling van mensenhandel heeft een aantal vroeg in de wetsgeschiedenis ontwikkelde uitgangspunten zijn betekenis niet verloren. Deze totstandkomingsgeschiedenis kan ons - wetgever, 
rechtspraktijk en rechtswetenschap - veel leren. Het verfrissende daarbij is dat er soms weinig nieuws onder de zon is.

We zullen zien dat de reikwijdte en strekking van de strafbaarstelling van mensenhandel in eerste instantie nauw zijn verweven met het Nederlandse prostitutiebeleid. Dat beleid kenmerkt zich, zoals dit overigens ook in andere landen het geval is, door de eeuwen heen door een proces van toenemende en afnemende overheidsinterventie. Vanaf het eind van de negentiende eeuw laat het overheidsoptreden een beweging zien van achtereenvolgens reglementeren, criminaliseren, gedogen en reguleren. Deze in de tijd gewijzigde maatschappelijke en politieke opvattingen over (de exploitatie van) prostitutie hebben hun weerslag gehad op de strafwetgeving inzake mensenhandel. Die strafwetgeving strekt zich dan ook lange tijd uitsluitend uit over handel ten behoeve van de prostitutie. Bovendien betreft mensenhandel volgens de strafwetgever aanvankelijk uitsluitend vrouwenhandel en is vrouwenhandel beperkt tot de handel in blanke slavinnen. Pas veel later worden onder invloed van internationale ontwikkelingen naast seksuele uitbuiting ook andere vormen van uitbuiting in arbeid en dienstverlening als mensenhandel strafbaar.

\subsubsection{1, Wet Bestrijding van Zedeloosheid}

De publieke aandacht voor vrouwenhandel ontstaat aan het eind van de negentiende eeuw en komt voort uit verontwaardiging in Europa over de handel in vrouwen - blanke slavinnen - ten behoeve van de prostitutie. De aandacht van de wetgever gaat in die tijd vooral uit naar de prostitutie als zodanig. De introductie van de eerste specifieke strafbaarstelling van vrouwenhandel in de Nederlandse strafwetgeving houdt dan ook nauw verband met het debat over prostitutie dat in die tijd in Nederland en elders in Europa oplaait. Dat debat wordt geïnitieerd en aangevoerd door de beweging van abolitionisten die streven naar een verbod op de exploitatie van prostitutie en ijveren voor afschaffing van de overheidsbemoeienis met prostitutie via het dan gevoerde beleid van reglementering. ${ }^{12} \mathrm{Na}$ een jarenlange maatschappelijke en politieke discussie over de strafbaarstelling van exploitatie van prostitutie valt in IgI2 uiteindelijk het doek voor de bordelen met de inwerkingtreding van de Wet Bestrijding van Zedeloosheid (wet van 20 mei I9II, Stb. I30). Die wet omvat een groot aantal aanscherpingen op het terrein van de zedelijkheid ${ }^{13}$, waaronder de bepaling die vanaf dat moment in de wandelgangen het bordeelverbod wordt genoemd, te weten artikel 25 obis $\mathrm{Sr}^{\mathrm{I}}{ }^{4}$ In dat artikel wordt strafbaar gesteld:

Zie uitgebreid over het prostitutiedebat in die tijd P.A. De Vries, Kuisheid voor mannen, vrijheid voor vrouwen; de reglementering en bestrijding van prostitutie in Nederland, 1850-1911, Uitg. Verloren, Hilversum 1997. Voorts R.H. Haveman, Voorwaarden voor strafbaarstelling van vrouwenhandel, Gouda Quint, Deventer I998, p. 97 e.v.

I3 Zie uitgebreid R.S.B. Kool, De strafwaardigheid van seksueel misbruik, Gouda Quint, I999, p. 56 e.v.

I4 Deze bepaling doet overigens haar intrede onder gelijktijdige schrapping van het enigszins ontroerende artikel $452 \mathrm{Sr}$ inzake de informatieplicht van de bordeelhouder dat in de strafwet van I886 was opgenomen: 'De bordeelhouder die in het huis waarin hij zijn bedrijf uitoefent, eene niet tot zijn gezin behorende vrouw opneemt, zonder haar vooraf, op voor haar verstaanbare wijze, in tegenwoordigheid van den burgemeester of van den door deze aangewezen ambtenaar, 
'hij die van het opzettelijke teweegbrengen of bevorderen van ontucht door anderen met derden een beroep of eene gewoonte maakt'.

Bij nota van wijziging wordt ook het verbod op souteneurschap aan het wetsvoorstel dat aan de Wet Bestrijding van Zedeloosheid ten grondslag ligt, toegevoegd en in het Wetboek van Strafrecht opgenomen. Zulks door aanvulling van artikel $432 \mathrm{Sr}$ met een onderdeel $3^{\circ}$ betreffende de strafbaarstelling als overtreding van:

'de souteneur die uit de opbrengst der ontucht van een vrouw voordeel trekt'. ${ }^{15}$

Vrouwenhandel maakt aanvankelijk geen onderdeel uit van het wetsvoorstel dat heeft geleid tot de Wet Bestrijding van Zedeloosheid. Wel wordt de introductie van het bordeelverbod gepresenteerd als belangrijke maatregel in de strijd tegen vrouwenhandel. Met het wegnemen van de afzetmarkt zou vanzelf ook de handel opdrogen. Tijdens de parlementaire behandeling van het wetsvoorstel wordt evenwel alsnog bij nota van wijziging een voorstel tot strafbaarstelling van vrouwenhandel ingevoegd. Het aanvankelijk door toenmalig minister van Justitie Regout voorgestelde artikel 25oter Sr luidt:

'Hij die eenige handeling pleegt, ondernomen met het oogmerk om eene vrouw aan prostitutie over te leveren, wordt als schuldig aan vrouwenhandel, gestraft met gevangenisstraf van ten hoogste vijf jaren. ${ }^{{ }^{1} 6}$

Deze door de minister voorgestelde formulering van vrouwenhandel stuit in de Tweede Kamer op veel kritiek. Als voornaamste bezwaar wordt aangevoerd dat de delictsomschrijving grote overlap vertoont met het in hetzelfde wetsvoorstel voorgestelde artikel 25obis Sr, waarin als gezegd het bordeelverbod - het beroepsmatig bevorderen van ontucht door anderen met derden - is neergelegd. ${ }^{17}$ Voorts wordt gewezen op het bezwaar dat met de voorgestelde formulering ook voorbereidingshandelingen en poging in alle gevallen strafbaar worden gesteld. Indachtig deze bezwaren stelt de Commissie van Rapporteurs uit de Tweede Kamer voor om af te zien van een delictsomschrijving. ${ }^{18}$ De minister neemt dat voorstel over, maar laat

op diens bureel te hebben bekend gemaakt met het bedrijf dat in dat huis wordt uitgeoefend, wordt gestraft met een hechtenis van ten hoogste drie maanden of geldboete van ten hoogste drie honderd gulden.' Het op 'verstaanbare wijze' was opgenomen met het oog op uit het buitenland afkomstige vrouwen.

I5 TK, zitting I909-I9Io, bijlage 56 , nr. 3 (gewijzigd ontwerp van wet); bij amendement is het aanvankelijk voorgestelde publieke vrouw teruggebracht tot vrouw. De strafbepaling betreffende souteneurschap dankt, naast een bewijstechnisch argument, haar bijzondere plaats aan het feit dat volgens de wetgever niet kan worden volstaan met het opleggen aan de souteneur van de gevangenisstraf van artikel 25 obis Sr, omdat de souteneur 'te lui of onbekwaam' wordt geacht 'voor enig beroep' en na invrijheidstelling zonder twijfel weer naar het souteneursbedrijf zou terugkeren. De bijzondere bijkomende straf van plaatsing in een rijkswerkinrichting, die regeling vond in artikel $432 \mathrm{Sr}$, wordt effectiever geacht.

I6 TK, zitting I9ıo-I9II, bijlage 28 , nr. 5 (ingezonden 20 februari I9II).

I7 Handelingen II, 55ste vergadering, 2 maart I9II, p. I572 e.v.

I8 Handelingen II, 55ste vergadering, 2 maart I9II, p. I575. 
voor de wetsgeschiedenis wel optekenen dat voor een veroordeling voor het voltooide delict vrouwenhandel de verwezenlijking van het oogmerk tot overlevering van de vrouw aan de prostitutie niet nodig is. ${ }^{19}$ Als voorbeeld noemt hij het reizen met een vrouw met het doel haar aan de prostitutie over te leveren. Voorts is van belang de opmerking van de minister dat ook een vrouw die reeds als prostituee werkzaam is, slachtoffer van vrouwenhandel kan zijn. ${ }^{20}$ De Commissie van Rapporteurs aanvaardt deze door de minister gegeven uitleg. Artikel 25oter Sr komt uiteindelijk als volgt te luiden:

'Vrouwenhandel wordt gestraft met gevangenisstraf van ten hoogste vijf jaren.'

\subsubsection{Internationale ontwikkelingen: de vroege verdragen ter bestrijding van vrouwenhandel}

Hoewel de omvang van vrouwenhandel in die tijd nog onduidelijk is, vormt de ernst van het verschijnsel voldoende aanleiding voor de totstandkoming van internationale instrumenten die zich richten op de bestrijding ervan. Na het sluiten van enkele bilaterale overeenkomsten met omliggende landen volgt een aantal multilaterale rechtsinstrumenten waarbij Nederland partij wordt. Ook de hier eerder beschreven strafbaarstelling van vrouwenhandel in de Wet Bestrijding van Zedeloosheid vindt mede haar grondslag in de uitvoering door Nederland van internationale verplichtingen. Het betreft het Verdrag van Parijs van 4 mei rgro tot bestrijding van de handel in vrouwen en meisjes (Stb. I9I2, 355). ${ }^{21}$ De artikelen I en 2 van dit Verdrag luiden:

I9 Handelingen II, 55ste vergadering, 2 maart I9II, p. I577. Volgens minister Regout dient 'elke handeling, ondernomen van het oogenblik dat men zich met de vrouw in aanraking stelt tot op het oogenblik, dat men de vrouw aan de prostitutie - wat men voornemens is - overlevert, op zich zelf reeds als "vrouwenhandel" gequalificeerd (...) te worden, m.a.w., dat voor het voltooide delict niet noodig zal zijn het verwezenlijken van het overleveringsoogmerk'. Deze opvatting is in het vervolg van de parlementaire behandeling niet weersproken. De wetgever lijkt de rechter alle ruimte te hebben willen laten bij de invulling van de betekenis van het begrip vrouwenhandel. Vanuit het oogpunt van legaliteit kunnen daarbij vraagtekens worden gezet. Opvallend is dat zowel door de minister van Justitie als door de Commissie van Rapporteurs wordt gesteld dat de rechter niet gebonden is aan de verklaringen in de Tweede Kamer over het voorgestelde wetsartikel. Simons reageert daarop in het Weekblad van het Recht met de opmerking: 'Indien de verschillende factoren van de wetgevende macht willen, dat naar hunne overeenstemmende opvatting worde geluisterd, behooren zij die opvatting in de wet zelf neer te leggen. Doen zij dit niet, dan laten zij den rechter vrij en openen zij eene rijkvloeiende bron voor rechtsonzekerheid.' D. Simons in Weekblad van het Recht (W. 9127 (I9II)).

20 TK, zitting I9I0-I9II, bijlage 28, nr. 5 (ingezonden 20 februari I9II). Volgens de toelichting op de nota van wijziging kan 'ook eene vrouw, die reeds publieke vrouw was, aan de prostitutie (...) worden overgeleverd, zoodat (...) niet behoeft te blijken van het oogmerk om eene vrouw bepaaldelijk tot prostitutie te doen vervallen.' Dit standpunt van de minister van Justitie wordt in de rechtsgeleerde literatuur direct overgenomen, zie T.J. Noyon I9I4, Het Wetboek van Strafrecht verklaard, Gouda Quint, Arnhem I9I4, dl. 2, p. 495.

2I Goedgekeurd bij wet van 30 maart I9I2 (Stb. I33), voor Nederland in werking getreden op 8 februari 19I3. Volledigheidshalve kan nog worden gewezen op de Internationale Regeling tot bestrijding van de zogenaamde handel in vrouwen en meisjes van I8 mei I904 (Stb. I907, 79). Deze voorloper van het Verdrag van Parijs verplicht partijen tot het nemen van een aantal maatregelen ter bestrijding van de grensoverschrijdende handel in vrouwen en meisjes. In het laatstgenoemde instrument zijn geen strafbaarstellingsverplichtingen opgenomen. Het omvat uitsluitend aspecten als het vergaren van informatie en het houden van toezicht. 


\section{'Artikel I}

Gestraft wordt ieder, die ter voldoening van eens anders lusten een minderjarige vrouw of meisje, zelfs met haar goedvinden, met het oog op het plegen van ontucht heeft aangeworven, medegenomen of ontvoerd, zelfs dan wanneer de verschillende handelingen die de bestanddelen van het strafbare feit uitmaken, in verschillende landen gepleegd zijn.

\section{Artikel 2}

Mede wordt gestraft ieder, die ter voldoening van eens anders lusten een meerderjarige vrouw of meisje door bedrog of met behulp van geweld, bedreiging, misbruik van gezag of enig ander dwangmiddel, met het oog op het plegen van ontucht heeft aangeworven, medegenomen of ontvoerd, zelfs dan wanneer de verschillende handelingen die de bestanddelen van het strafbare feit uitmaken, in verschillende landen gepleegd zijn.'

Het verdrag maakt onderscheid tussen handel in minderjarige en handel in meerderjarige vrouwen. In de strafbaarstelling van handel in minderjarige vrouwen ontbreekt het bestanddeel dwang, terwijl dat bestanddeel aan de strafbaarstelling van handel in meerderjarige vrouwen als beperkende voorwaarde is verbonden. Uit de eerder beschreven wetsgeschiedenis van artikel 250ter Sr blijkt dat de wetgever aan die bepaling een ruimere reikwijdte heeft gegeven dan waartoe het verdrag van igıo verplicht. Het dan geldende artikel $250 t e r$ Sr maakt immers geen onderscheid tussen minderjarige en meerderjarige vrouwen; ten aanzien van beide geldt dat voor strafbaarheid de vrije wil van de vrouw niet relevant is. Voorts omvat het begrip vrouwenhandel zoals dat in de wetsgeschiedenis gestalte heeft gekregen meer gedragingen dan de in het verdrag van Igro genoemde gedragingen aanwerven, medenemen of ontvoeren. $^{22}$

Na de totstandkoming van het verdrag van IgIo volgen verschillende verdragen die daarop aanvullingen bevatten. Het eerste verdrag is het Verdrag van Genève van 30 september I92I ter bestrijding van de handel in vrouwen en kinderen (Stb. I923, 526). ${ }^{23}$ De belangrijkste aanvulling in dit verdrag betreft, voor zover hier van belang, de verplichting tot het strafbaar stellen van de handel in minderjarige jongens. ${ }^{24} \mathrm{Het}$

22 Uit de toelichting op artikel 25oter Sr blijkt dat van regeringszijde de strafbaarstelling van vrouwenhandel in het verdrag van I9Io wordt beschouwd als een misdrijf tegen de persoonlijke vrijheid, maar dat de regering er bewust voor heeft gekozen het als een misdrijf tegen de zeden aan te merken (zie TK, zitting I9IO-I9II, bijlage 28, nr. 5). Deze keuze zou verband kunnen houden met het feit dat - zoals wel is gesteld - de internationale verplichting tot strafbaarstelling van vrouwenhandel vooral werd gebruikt ter ondersteuning van het door de regering nagestreefde bordeelverbod en minder vanwege een geconstateerde noodzaak tot bestrijding van vrouwenhandel zelf. Het bordeelverbod wordt daarbij als enige echt effectieve maatregel tegen internationale vrouwenhandel gepropageerd. Zie Haveman, a.w., p. I28.

23 Goedgekeurd bij wet van I7 juli I923 (Stb. 395), voor Nederland in werking getreden op i9 september 1923 .

24 Vermelding verdient dat de Nederlandse regering zich tijdens de onderhandelingen over dit verdrag in Genève heeft beijverd voor aanscherping van de strafbaarstelling van vrouwenhandel 
verdrag biedt dus bescherming aan kinderen van beide geslachten. Ter uitvoering van dit verdrag is de strafbaarstelling in artikel 25oter Sr uitgebreid tot handel in minderjarigen van het mannelijk geslacht. ${ }^{25}$ Artikel $250 t e r$ Sr luidt vanaf dat moment als volgt:

'Vrouwenhandel en handel in minderjarigen van het mannelijk geslacht wordt gestraft met gevangenisstraf van ten hoogste vijf jaren of geldboete van de vierde categorie.'

Niet lang daarna volgt de totstandkoming van nog een ander belangrijk verdrag, het Internationaal Verdrag van Genève van II oktober 1933 nopens de bestrijding van de handel in meerderjarige vrouwen (Stb. 1935, 598). ${ }^{26}$ In dat verdrag worden de verdragen uit I9I0 en I92I aangevuld met de verplichting tot strafbaarstelling van het aanwerven van een meerderjarige vrouw, zelfs met haar goedvinden, met het oog op het plegen van ontucht in een ander land. Artikel I van dit verdrag luidt:

'Gestraft wordt ieder, die, ter voldoening van eens anders lusten, eene meerderjarige vrouw of meisje, zelfs met haar goedvinden, met het oog op het plegen van ontucht in een ander land, heeft aangeworven, medegenomen of ontvoerd, zelfs dan wanneer de verschillende handelingen, die de bestanddeelen van het strafbare feit uitmaken, in verschillende landen gepleegd zijn. De poging is eveneens strafbaar. Hetzelfde is het geval, binnen de grenzen der wet, met voorbereidende handelingen.'

De strafbaarstellingsverplichting uit het verdrag van 1933 ziet derhalve op grensoverschrijdende vrouwenhandel. Bij die buitenlandse handel is de vrije wil van de vrouw, ook wanneer zij meerderjarig is, niet langer relevant. De binnenlandse handel wordt door de verdragsopstellers bewust buiten de reikwijdte van het verdrag gehouden. Dit houdt verband met het feit dat een aantal landen ten aanzien van de prostitutie nog een beleid van reglementering voert, dat zich niet goed laat verenigen met een verplichting om in de nationale strafwetgeving ten aanzien van de binnenlandse handel het dwangvereiste te laten vervallen. ${ }^{27}$ De uitvoering van dit verdrag door Nederland noopt niet tot wetswijziging. Immers, zoals wij reeds zagen is op grond van het dan geldende artikel 25oter Sr zowel binnenlandse als buitenlandse vrouwenhandel ook bij het ontbreken van dwang strafbaar. ${ }^{28}$ Later zullen we nog zien dat de uit het verdrag voortvloeiende verplichting tot strafbaarstelling van het werven 'over de grens', ongeacht de aanwezigheid van enigerlei vorm van dwang, in

door het laten vervallen van het vereiste van dwang ten aanzien van meerderjarige vrouwen. Dit voorstel kreeg evenwel onvoldoende steun. Zie Haveman, a.w., p. I48.

25 Wet van I3 mei 1927 (Stb. I56).

26 Goedgekeurd bij wet van 2 augustus I935 (Stb. 443), voor Nederland in werking getreden op I9 november 1935 .

27 Zie Haveman, a.w., p. I48.

28 Wel is er discussie over de vraag of het dan voor artikel $250 t e r$ Sr geldende strafmaximum van vijf jaar voldoet aan de in artikel 2 van het verdrag opgenomen verplichting te voorzien in een strafbedreiging waarin de ernst van de in het verdrag omschreven gedragingen tot uitdrukking komt. Gepleit wordt voor een strafmaximum van I2 jaar (gelijk aan slavenhandel en mensenroof), maar tot wetswijziging komt het niet. Zie Haveman, a.w., p. I49. 
het licht van de opheffing van het bordeelverbod tot veel discussie aanleiding geeft (zie de bespreking van wetsvoorstel I8 202 en wetsvoorstel 2I 027).

De hier besproken verdragen van I9I0, I92I en I933 zijn uiteindelijk vervangen door het op 2 december 1949 door de Algemene Vergadering van de Verenigde Naties aanvaarde Verdrag tot bestrijding van de handel in mensen en de exploitatie van prostitutie. ${ }^{29}$ Dit verdrag verplicht niet alleen tot strafrechtelijke bestrijding van handel in mensen ten behoeve van de prostitutie, maar ook tot strafrechtelijke bestrijding van de exploitatie van prostitutie, zelfs indien de betrokken prostituee meerderjarig is en met die exploitatie instemt. Duidelijk is dat dit verdrag is gestoeld op het abolitionisme, welke beweging in die tijd op het niveau van de Verenigde Naties sterk vertegenwoordigd is..$^{3 \circ}$ De preambule van het verdrag laat over de abolitionistische insteek geen enkel misverstand bestaan door de verdragsbepalingen in te leiden met de overweging dat:

'prostitution and the accompanying evil of the traffic in persons for the purpose of prostitution are incompatible with the dignity and worth of the human person and endanger the welfare of the individual, the family and the community'.

Een belangrijke uitbreiding in het verdrag van 1949 ten opzichte van de eerdere verdragen zit voorts in het feit dat het verdrag ertoe verplicht om ook bij de binnenlandse handel het dwangvereiste los te laten. Voorts strekt de strafrechtelijke bescherming tegen handel ten behoeve van de prostitutie zich ook uit over meerderjarige mannen.

Nederland heeft het verdrag van 1949 niet bekrachtigd. Het belangrijkste argument daarvoor is gelegen in het Nederlandse prostitutiebeleid. In de periode na de totstandkoming van het verdrag vat in toenemende mate de mening post dat tot uitgangspunt moet worden genomen het onderscheid tussen vrijwillige en gedwongen vormen van exploitatie van prostitutie. De inzet van het strafrecht dient te zijn gericht op vormen van exploitatie waarbij sprake is van enigerlei vorm van dwang. De kern van de bezwaren tegen het verdrag van 1949 is - op een later moment - als volgt omschreven in de memorie van toelichting bij het wetsvoorstel (het hierna nog te bespreken wetsvoorstel 2I 027) dat ten grondslag ligt aan de Wet van 9 december I993 (Stb. 679):

'Voor zover het Verdrag van 1949 de staten ook verplicht strafrechtelijk op te treden tegen exploitatie van prostitutie van volwassen onafhankelijke vrouwen die met die exploitatie uit vrije wil hebben ingestemd, is ratificatie van het verdrag niet verenigbaar Verenigde Naties het verdrag van I9Io (bij protocol van 3 december 1948) en de verdragen van I92I en I933 (bij protocol van 20 oktober I947) eerder al omgezet in verdragen gesloten in het kader van de Verenigde Naties. Zie ook N-L-R, 'Het Wetboek van Strafrecht', aantek. I bij artikel $273 \mathrm{f} \mathrm{Sr}$.

30 Zie ook R. Haveman, 'Slavernij of reguliere arbeid', Nemesis I995, nr. 4, p. 97-I02. 
met het Nederlandse strafrechtelijke beleid ter zake. De gedachten die ten grondslag liggen aan dit beleid, zijn de volgende:

Uit het recht op zelfbeschikking dat een volwassen onafhankelijke vrouw of man die niet aan ongeoorloofde beïnvloeding is blootgesteld, heeft, vloeit voort dat zij of hij vrijwillig kan besluiten zich te prostitueren en een ander uit de opbrengst van die prostitutie te bevoordelen. Exploitatie van prostitutie is een maatschappelijke realiteit die niet door een absoluut verbod tot verdwijning kan worden gebracht. Exploitatie van prostitutie die gepaard gaat met een uitbuitingssituatie, dient krachtig te worden bestreden. Niet de strafrechtelijke bevordering van de zedelijkheid, die het VN-verdrag van 2 december 1949 klaarblijkelijk beoogt, is doelstelling van de Nederlandse strafrechtspolitiek, maar de bescherming van hen die onvrijwillig tot prostitutie komen, waarbij de term "onvrijwillig" ruim wordt opgevat. De bestrijding van prostitutie als gevolg van een uitbuitingssituatie kan naar de mening van de regering effectiever geschieden, indien de mogelijkheid van een niet verboden vorm van exploitatie van prostitutie bestaat. Deze niet verboden vorm van exploitatie kan immers door de overheid door middel van voorschriften worden gereguleerd met het oog op de bescherming van de gezondheid en veiligheid van de prostitué(e). ${ }^{31}$

De pijn zit voor Nederland dus in de belangrijkste aanvulling van het verdrag van I949 ten opzichte van de voorlopers die het vervangt, te weten de verplichting tot strafbaarstelling van exploitatie van prostitutie. ${ }^{32}$ Het verdrag is overigens waarschijnlijk om die reden door een minderheid van staten geratificeerd. ${ }^{33}$ Voor de landen die het verdrag van 1949 niet hebben geratificeerd, gelden nog steeds de eerdere verdragen van I9IO, I92I en I933. ${ }^{34}$ Het feit dat Nederland geen partij is bij het verdrag van 1949 laat de gebondenheid aan diens voorlopers derhalve onverlet.

\subsubsection{Wetsvoorstel 18202}

We keren terug naar de bespreking van de nationale beleidsontwikkelingen die hebben bijgedragen aan de totstandkoming van de strafbaarstelling van mensenhandel in haar huidige vorm.

Bij koninklijke boodschap van 20 december 1983 wordt onder verantwoordelijkheid van minister van Justitie Korthals Altes een wetsvoorstel tot afschaffing van de bijkomende straf van plaatsing in een rijkswerkinrichting en wijziging van de strafbepaling betreffende souteneurschap aan de Tweede Kamer aangeboden. ${ }^{35}$ De directe aanleiding voor dat wetsvoorstel is gelegen in het feit dat de bijkomende

3I Kamerstukken II I988/89, 2I 027, nr. 3, p. 6. Zie ook Handelingen II, 2I mei I992, 8I-4978.

32 Op de vraag of Nederland niet met een voorbehoud wat betreft de strafbaarstelling van exploitatie van prostitutie alsnog partij zou kunnen worden bij het verdrag, antwoordt de minister van Justitie dat die strafbaarstelling een zo belangrijk onderdeel van het verdrag vormt dat toetreding met een voorbehoud, indien al mogelijk, weinig zinvol zou zijn (Kamerstukken II I990/9I, 2I 027, nr. 5, p. 9).

33 Het Verdrag is door 74 landen geratificeerd (stand september 20I0).

34 Kamerstukken II I990/9I, 2I 027, nr. 5, p. 9.

35 Kamerstukken II I983/84, I8 202, nrs. I-3. 
straf van plaatsing in een rijkswerkinrichting, oplegging waarvan bij veroordeling voor bepaalde delicten in artikel $432 \mathrm{Sr}$ regeling vindt, uit de tijd wordt geacht en in onbruik is geraakt. Met die bijkomende straf van plaatsing in een rijkswerkinrichting houdt (naast de strafbaarstelling van bedelarij en landloperij, die hier verder buiten beschouwing blijft) nauw verband de strafbaarstelling van souteneurschap, aangezien die is neergelegd in artikel 432 , onderdeel $3^{\circ}$, Sr. Het souteneursverbod heeft op dat moment in die vorm - gelet op het beperkt aantal veroordelingen - vrijwel geen betekenis meer. ${ }^{36}$ Op de achtergrond speelt bovendien het uit 1964 daterend rapport van de commissie-Stoffels, waarin een wetswijziging inzake de strafbaarstelling van souteneurschap wordt voorgesteld. ${ }^{37}$ De voorgenomen schrapping van artikel 432 Sr noopt de wetgever ook tot bezinning over en wijziging van de strafbaarstelling van souteneurschap. Door die exercitie zal het wetsvoorstel, alhoewel het daarover aanvankelijk met geen woord rept, evenwel onbedoeld een even hevige als langdurige discussie over de afschaffing van het bordeelverbod ontketenen.

Minister Korthals Altes verwijst ter onderbouwing van zijn wetsvoorstel tevens naar de bevindingen van de adviescommissie zedelijkheidswetgeving (commissieMelai), die in haar derde interimrapport Prostitutie uitgebreid ingaat op de rol van de strafwetgever ten aanzien van prostitutie en de vraag of de daarop betrekking hebbende strafbepalingen wijziging behoeven. ${ }^{8}$ Uit de conclusies van de commissie-Melai trekt de minister de consequentie dat de beperking van de wilsvrijheid van de prostituee centraal dient te staan bij de strafrechtelijke benadering van het souteneurschap. In deze benadering wordt strafwaardig geacht het aanwenden van dwang die de prostituee ertoe brengt de souteneur uit de opbrengst van seksuele handelingen met derden geheel of ten dele te onderhouden. Dit leidt tot het voorstel van de minister om de strafbepaling inzake souteneurschap over te brengen naar de misdrijven en de strafbaarstelling, in een nieuw artikel 25oter Sr, te beperken tot gedragingen die gepaard gaan met enigerlei vorm van dwang. Artikel 25oter $\mathrm{Sr}$

36 Kamerstukken II I983/84, I8 202, nrs. I-3, p. 7.

37 'Prostitutie en Strafrecht', rapport van de commissie ingesteld bij besluit van de minister van Justitie van 2 I maart 1962, Stafafdeling Wetgeving nr. 88/662, Staatsuitgeverij, Den Haag I964. De commissie wordt naar haar voorzitter, de heer mr. H.K.A. Stoffels (raadsheer in het Gerechtshof Den Haag), commissie-Stoffels genoemd. De commissie-Stoffels stelt voor om als misdrijf strafbaar te stellen de 'souteneur die een ander beweegt hem uit diens ontucht te bevoordelen'. Met die delictsomschrijving richt de commissie zich tot wat zij omschrijft als de 'actieve-souteneur'. Voor strafbaarheid is volgens de commissie vereist dat de souteneur 'enige activiteit in welke vorm ook moet hebben uitgeoefend op de zich prostituerende om geld of onderhoud boven de mate van diens vrijwilligheid te verschaffen.' (zie p. 35-36 rapport).

38 Derde interimrapport van de adviescommissie zedelijkheidswetgeving, 'Prostitutie', Staatsuitgeverij, Den Haag 1977. De commissie legt een verband tussen de toelaatbaarheid van exploitatie van prostitutie en de inperking van de rechten van de prostituee. Daarbij kan volgens de commissie de mate waarin inbreuk wordt gemaakt op het zelfbeschikkingsrecht van de prostituee op een glijdende schaal worden aangegeven. Aan het ene uiteinde de prostituee die volledig onafhankelijk is, aan het andere uiteinde de prostituee die zodanig wordt geëxploiteerd dat de individuele zeggenschap ontbreekt. In dit model is de inzet van het strafrecht volgens de commissie aanvaardbaar indien sprake is van een inbreuk op de rechten en belangen van de prostituee (p. I2 rapport). Overigens verbindt de commissie zelf aan haar conclusies geen voorstel tot wetswijziging. 
(vrouwenhandel en handel in minderjarige jongens) zou dan worden vernummerd tot artikel 25oquater Sr. Het door de minister voorgestelde artikel 25oter (nieuw) Sr luidt:

'hij die als souteneur een ander door geweld of een andere feitelijkheid of door bedreiging met geweld of een andere feitelijkheid dwingt hem uit de opbrengst van diens seksuele handeling te bevoordelen, wordt gestraft met gevangenisstraf van ten hoogste achttien maanden of geldboete van de vierde categorie'. ${ }^{39}$

Met betrekking tot de omschrijving van dwang wordt dus aanvankelijk aangesloten bij de dwangmiddelen zoals opgenomen in de algemene dwangbepaling van artikel $284 \mathrm{Sr}$ (geweld of enige andere feitelijkheid of bedreiging met geweld of enige andere feitelijkheid).

Tijdens de behandeling van het wetsvoorstel door de Tweede Kamer wordt uitvoerig stilgestaan bij de verhouding van het voorgestelde artikel 25oter (nieuw) tot het bestaande artikel 25obis Sr, waarin het bordeelverbod is neergelegd. Onder de delictsomschrijving van het dan geldende artikel 25obis Sr kunnen immers in het algemeen ook de activiteiten van de souteneur die zich niet bedient van enigerlei vorm van dwang worden gebracht. Dit leidt tot de conclusie dat alleen al vanuit het oogpunt van consistente wetgeving de introductie van het voorgestelde artikel $250 t e r$ (nieuw) Sr niet goed verenigbaar is met handhaving van het geldende artikel 25obis Sr. Dat brengt het wetsvoorstel in het politiek roerige vaarwater van het bordeelverbod.

Door verscheidene fracties uit de Tweede Kamer wordt erop gewezen dat het verbod van artikel 25obis Sr ook om andere reden wijziging behoeft: het bordeelverbod wordt niet gehandhaafd, terwijl het wel belemmerend werkt bij het voeren van gemeentelijk prostitutiebeleid. Bij een meerderheid van de Tweede Kamer bestaat nadrukkelijk de wens tot aanpassing van artikel 25obis Sr opdat gemeenten in de gelegenheid worden gesteld ten aanzien van de exploitatie van prostitutie een vergunningenbeleid te voeren, hetgeen moet leiden tot een betere bescherming van de positie van de prostituee. In feite wordt de discussie over het wetsvoorstel vanaf dan volledig beheerst door de verschillende zienswijzen op (de afschaffing van) het bordeelverbod. $4^{\circ}$ Uiteindelijk resulteert deze discussie in het voorstel van een Kamermeerderheid om artikel 25obis Sr van het element dwang te voorzien en de eerder ter zake souteneurschap als artikel 25oter Sr voorgestelde bepaling uit het

39 Kamerstukken II I983/84, I8 202, nrs. I-3, p. II: 'Niet het functioneren als souteneur waaraan immers het voordeel trekken uit de opbrengst van het prostitutiebedrijf van de partner inherent is, wordt in deze gedachtengang strafwaardig geacht, maar het aanwenden van enigerlei dwang welke de prostituée er toe brengt de souteneur uit de opbrengst van haar seksuele activiteiten met derden geheel of ten dele te onderhouden.' Ook in het rapport van de commissie-Stoffels werd geconcludeerd dat de souteneur die de vrijheid van de prostituee niet beïnvloedt, niet onder de strafwet behoort te vallen.

Zie uitgebreid Haveman, a.w., p. I79 e.v. 
wetsvoorstel te schrappen..$^{4 \mathrm{I}}$ Dit voorstel, dat de opheffing van het bordeelverbod betekent, wordt door minister Korthals Altes graag aanvaard. Bij nota van wijziging wordt, onder schrapping van het aanvankelijk voorgestelde artikel $250 t e r \mathrm{Sr}$, artikel 25obis Sr zodanig gewijzigd dat de strafbaarheid zich beperkt tot:

\begin{abstract}
'degene die een ander door geweld of een andere feitelijkheid of door bedreiging met geweld of een andere feitelijkheid dwingt, dan wel door misbruik van uit feitelijke verhoudingen voortvloeiend overwicht of door misleiding beweegt hem of haar uit de opbrengst van zijn of haar seksuele handelingen te bevoordelen'. ${ }^{42}$
\end{abstract}

Deze strafbaarstelling richt zich dus zowel tot de souteneur als tot de bordeelhouder, voor zover zij inbreuk maken op de wilsvrijheid van de prostituee. ${ }^{43}$ Zoals blijkt uit de toelichting op de nota van wijziging acht de wetgever het - 'in verband met de afschaffing van het bordeelverbod' - wenselijk om de strafrechtelijke bescherming van de prostituee uit te breiden ten opzichte van de in het oorspronkelijk voorgestelde artikel 25oter (nieuw) Sr opgenomen - aan artikel $284 \mathrm{Sr}$ ontleende omschrijving van dwang. Om die reden worden aan de middelen waarmee enigerlei vorm van dwang kan worden uitgeoefend ook bepaalde middelen van 'bewegen' in de delictsomschrijving van het voorgestelde artikel 25obis Sr opgenomen. Later zullen die middelen ook belangrijke ingrediënten voor de delictsomschrijving van mensenhandel blijken. Het gaat om: misbruik van uit feitelijke verhoudingen voortvloeiend overwicht en misleiding. ${ }^{44}$ Misleiding zou vooral ten aanzien van buitenlandse prostituees veel voorkomen. ${ }^{45}$ Over de grens tussen vrijwilligheid en dwang wordt in de wetsgeschiedenis opgemerkt dat sprake is van dwang wanneer betrokkene kan menen geen reële keuze te hebben anders dan aan de eisen van de souteneur of bordeelhouder te voldoen. Deze dwang kan volgens de wetgever ook betrekking hebben op de voortzetting van een verhouding die aanvankelijk vrijwillig wordt aangegaan. ${ }^{4}$

4I Kamerstukken II I983/84, I8 202, nr. 4, p. 5 .

42 Kamerstukken II I985/86, I8 202, nr. 6 (nota van wijziging).

43 Door de accentverschuiving in de delictsomschrijving naar dwang en het feit dat aantasting van de keuzevrijheid centraal staat, wordt tijdens de mondelinge behandeling in de Tweede Kamer de vraag gesteld of het delict niet beter in titel XVIII van het Wetboek van Strafrecht als misdrijf tegen de persoonlijke vrijheid strafbaar kan worden gesteld. In reactie daarop spreekt de minister van Justitie de bereidheid uit dat bij gelegenheid te zullen bezien (Handelingen II, 2 april 1987, 66-3494). Later wordt de Tweede Kamer op haar wenken bediend (zie noot Ioo).

44 Kamerstukken II I985/86, I8 202, nr. 6 (nota van wijziging). Tijdens de mondelinge behandeling in de Tweede Kamer komt de vraag aan de orde waarom in de voorgestelde delictsomschrijving wordt gesproken van 'misbruik van uit feitelijke verhoudingen voortvloeiend overwicht' in plaats van 'misbruik van gezag' (zoals te doen gebruikelijk en tevens opgenomen in artikel 2 van het verdrag van I9Io). In reactie op deze vraag geeft de minister van Justitie aan dat 'misbruik van uit feitelijke verhoudingen voortvloeiend overwicht' een ruimere strekking heeft; dit misbruik kan bijvoorbeeld worden teruggevoerd op een groot leeftijdsverschil of economische omstandigheden (Handelingen II, 2 april I987, 66-3494).

45 Kamerstukken II I985/86, I8 202, nr. 5, p. 4.

46 Kamerstukken II I985/86, I8 202, nr. 5, p. 7 en Kamerstukken II I986/87, I8 202, nr. Io, p. 4-5. 
Bij de behandeling door de Tweede Kamer van wetsvoorstel I8 202 richt alle aandacht zich vervolgens begrijpelijkerwijs op de voorgestelde wijziging van artikel $250 \mathrm{bis} \mathrm{Sr}$, de opheffing van het bordeelverbod. Over het voorstel tot afschaffing van de bijkomende straf van plaatsing in een rijkswerkinrichting wordt niet meer gesproken. Ook de dan geldende strafbaarstelling van vrouwenhandel en handel in minderjarige jongens in artikel 25oter Sr komt tijdens de parlementaire behandeling in de Tweede Kamer nauwelijks ter sprake. ${ }^{47}$

Hoewel het wetsvoorstel in het voorjaar van I987 door de Tweede Kamer met algemene stemmen wordt aanvaard, stuit het in de Eerste Kamer op sterke weerstand. De behandeling in de Eerste Kamer staat vrijwel volledig in het teken van een discussie over de - door de christelijke partijen - naar voren gebrachte bezwaren tegen de opheffing van het bordeelverbod. Die bezwaren spitsen zich vooral toe op de vrees dat, wanneer de bedrijfsmatige exploitatie van prostitutie niet langer is verboden, aan dergelijke bedrijven subsidies zouden moeten worden verleend. Men huivert bij de gedachte dat de overheid zich na afschaffing van het bordeelverbod al te zeer met de prostitutiebranche moet inlaten. De verdere bespreking van deze discussie kan hier achterwege blijven. ${ }^{48}$

Wel komt in de Eerste Kamer ook de relatie tot vrouwenhandel naar voren. Vrouwenhandel is dan in de publieke aandacht gekomen, omdat uit onderzoek is gebleken dat het bepaald geen marginaal verschijnsel is. Van belang is vooral dat in de schriftelijke gedachtewisseling met de Eerste Kamer nader wordt ingegaan op het bestanddeel 'misbruik van uit feitelijke verhoudingen voortvloeiend overwicht' in het voorgestelde artikel 25obis Sr. Minister Korthals Altes verwijst naar het standpunt dat hij daarover eerder ook in de Tweede Kamer tijdens een Uitgebreide Commissievergadering van de vaste commissie voor Emancipatiebeleid over vrouwenhandel heeft ingenomen. ${ }^{49} \mathrm{Bij}$ die gelegenheid heeft de minister de standpunten die zijn ontwikkeld door de Werkgroep Vrouwenhandel, ingesteld door de vergadering van procureurs-generaal, tot de zijne gemaakt..$^{\circ}$ Een van die standpunten houdt in dat het bestanddeel 'misbruik van uit feitelijke verhoudingen voortvloeiend overwicht' vervuld moet worden geacht indien de prostituee in een situatie verkeert die niet gelijk is aan de omstandigheden waarin een mondige prostituee in Nederland pleegt te verkeren. Volgens de minister worden door deze interpretatie de opsporing en vervolging van de bordeelhouder die het voorgestelde artikel $250 \mathrm{obis} \mathrm{Sr}$

47 Wel wordt gevraagd het strafmaximum in artikel 25oter Sr te verhogen tot zes jaar in verband met de toepassing van voorlopige hechtenis. Dat wordt door de minister afgehouden met het argument dat de mogelijkheid tot toepassing van voorlopige hechtenis bij het geldende strafmaximum van vijf jaar onder omstandigheden (gevaar voor gezondheid of veiligheid personen) reeds bestaat. In het kort daarop door de minister aangekondigde wetsvoorstel (2I 027) tot wijziging van de artikelen 25 obis en $250 t e r$ Sr wordt evenwel voor beide artikelen alsnog een strafmaximum van zes jaar voorgesteld.

48 Zie daarover uitgebreid Haveman, a.w., p. I8I-I83.

49 Handelingen II I987/88, U.C.V. nr. 32, p. 20-21. Zie voor een uitvoerige beschrijving van deze uitgebreide commissievergadering Haveman, a.w., p. I83 e.v.

50 Rapport van de Werkgroep Vrouwenhandel, I5 november I988. 
overtreedt, sterk vereenvoudigd. Het enkele feit dat een buitenlandse prostituee in een uitbuitingssituatie wordt aangetroffen, levert reeds een vermoeden van schuld op..$^{\text {I }}$ De hiervoor vermelde uitleg van het bestanddeel 'misbruik van uit feitelijke verhoudingen voortvloeiend overwicht' zal vooral ook voor de strekking van de strafbaarstelling van mensenhandel van grote betekenis blijken.

Voorts wordt door de minister tijdens de schriftelijke gedachtewisseling met de Eerste Kamer over wetsvoorstel I8 202 een wetsvoorstel tot wijziging van de strafbaarstelling van vrouwenhandel en handel in minderjarige jongens in artikel 25oter Sr aangekondigd (het hierna te bespreken wetsvoorstel 2I 027). In dit wetsvoorstel zullen ten aanzien van de nieuw voorgestelde delictsomschrijving van mensenhandel dezelfde standpunten zijn terug te vinden als die welke door de minister naar voren zijn gebracht tijdens voornoemde commissievergadering over vrouwenhandel. In dit wetsvoorstel wordt ook artikel 25obis Sr weer gewijzigd. Aanvankelijk heeft die wijziging in hoofdzaak betrekking op een verhoging van het strafmaximum..$^{2}$ Conform een aanbeveling van de eerder vermelde Werkgroep Vrouwenhandel wordt voorgesteld om de strafmaxima van artikel 25obis en 250ter Sr beide op zes jaar te stellen. De grens tussen vrouwenhandel en de exploitatie van verhandelde vrouwen wordt gezien als vloeiend. De gelijkstelling van de strafmaxima voor ontoelaatbare exploitatie van prostitutie en mensenhandel is van belang voor de gevallen waarin niet kan worden achterhaald of aangetoond door wiens toedoen - de bordeelhouder zelf of een derde - het slachtoffer in de prostitutie is beland. Artikel $250 t e r \mathrm{Sr}$ is dan niet bruikbaar. Tegen de bordeelhouder die misbruik maakt van de ontstane uitbuitingssituatie, zal evenwel op grond van artikel 25obis Sr kunnen worden opgetreden. Om die reden wordt dezelfde strafbedreiging als in artikel 250 ter $\mathrm{Sr}$ - mede gelet op de wenselijkheid om dwangmiddelen te kunnen toepassen - passend geacht. ${ }^{53}$ Door de onderlinge afstemming van beide strafbepalingen is het onderscheid tussen enerzijds ongeoorloofd souteneurschap of ongeoorloofde exploitatie van prostitutie en anderzijds vrouwenhandel niet van belang voor de strafrechtelijke bescherming van het slachtoffer. ${ }^{54}$

Wetsvoorstel 2I 027 wordt bij de Tweede Kamer ingediend nog vóór de mondelinge behandeling in de Eerste Kamer van wetsvoorstel I8 202. Op voorstel van de minister van Justitie - dat is dan de inmiddels aangetreden minister Hirsch Ballin besluit de Eerste Kamer om de mondelinge behandeling van wetsvoorstel I8 202 aan te houden met het oog op een gelijktijdige behandeling van beide wetsvoorstellen.

5I Kamerstukken I I987/88, i8 202, nr. 248, p. 7; zie ook het rapport van de Werkgroep Vrouwenhandel, p. 23.

52 Kamerstukken II I990/9I, 2I 027, nr. 6 (nota van wijziging). Later zal daaraan - door de opvolger van minister Korthals Altes, minister Hirsch Ballin - bij tweede nota van wijziging nog een veel ingrijpender wijziging van artikel 25obis Sr worden toegevoegd (zie 2.I.6).

53 Kamerstukken I I987/88, I8 202, nr. 248, p. 7.

54 Kamerstukken II I990/9I, 2I 027, nr. 5, p. I. 


\subsubsection{Wetsvoorstel 21027}

Bij koninklijke boodschap van II februari I989 wordt - nog onder verantwoordelijkheid van minister van Justitie Korthals Altes - het reeds genoemde wetsvoorstel 2I 027, dat strekt tot wijziging van de artikelen 25obis en 25oter Sr, aan de Tweede Kamer aangeboden. Het wetsvoorstel strekt primair tot aanscherping en verbreding van de strafbaarstelling van vrouwenhandel. De in artikel 25oter Sr omschreven gedragingen worden gekwalificeerd als mensenhandel, teneinde ook de handel in meerderjarige mannen onder de strafbaarstelling te brengen. Vrouwenhandel wordt vanaf nu mensenhandel. ${ }^{55}$ En mensenhandel wordt van een delictsomschrijving voorzien. Artikel 250 ter Sr wordt zodanig gewijzigd dat op grond van lid I, onderdeel $\mathrm{I}^{\circ}$ - onder bedreiging met een gevangenisstraf van zes jaar - schuldig aan mensenhandel is:

'degene die een ander door geweld of een andere feitelijkheid of door bedreiging met geweld of een andere feitelijkheid dan wel door misbruik van uit feitelijke verhoudingen voortvloeiend overwicht of door misleiding tot prostitutie brengt, dan wel onder voornoemde omstandigheden enige handeling onderneemt waarvan hij of zij weet of redelijkerwijs moet vermoeden dat die ander daardoor in de prostitutie belandt'..$^{6}$

Wat betreft de in de delictsomschrijving gegeven opsomming van ongeoorloofde middelen sluit het voorgestelde artikel 25 oter lid I, onderdeel I ${ }^{\circ}, \mathrm{Sr}$ aan bij het voorgestelde artikel 25obis Sr in wetsvoorstel I8 202 dat op dat moment bij de Eerste Kamer aanhangig is. Daardoor is de samenhang tussen beide delicten duidelijk. Handel en exploitatie zijn feitelijk nauw met elkaar verweven, maar worden door de wetgever van elkaar onderscheiden. Strafbare handel is het met geweld, misbruik of misleiding een ander tot prostitutie brengen (artikel 25oter in wetsvoorstel 21 027), strafbare exploitatie het met geweld, misbruik of misleiding zich uit de opbrengsten van prostitutie door een ander bevoordelen (artikel 25obis $\mathrm{Sr}$ in wetsvoorstel I8 202). 57

In de memorie van toelichting bij wetsvoorstel 2I 027 wordt uitvoerig stilgestaan bij de strekking van het bestanddeel 'misbruik van uit feitelijke verhoudingen voortvloeiend overwicht' in artikel 25oter Sr. In de toelichting daarop staat het begrip uitbuitingssituatie centraal. Zoals eerder aangegeven, wordt door de wetgever het bestanddeel 'misbruik van uit feitelijke verhoudingen voortvloeiend overwicht' geacht te zijn vervuld:

55 Kamerstukken II I988/89, 2I 027, nr. 3, p. 3.

56 Kamerstukken II I988/89, 2I 027, nrs. I-2. Er wordt dus ook een culpoze variant geïntroduceerd: 'redelijkerwijs moet vermoeden'. Voldoende is indien aan de schuld van de dader is te wijten dat het slachtoffer in de prostitutie belandt. Volgens de memorie van antwoord kan van zodanige handeling bijvoorbeeld sprake zijn 'in het geval dat wordt bemiddeld voor werkzaamheden aan de bar in bepaalde inrichtingen, als animeermeisje of stripteasedanseres.' (Kamerstukken II I990/9I, 2I 027, nr. 5, p. 6).

57 Haveman, a.w., p. I86-I87. 
'indien de prostitué(e) in een situatie verkeert of komt te verkeren die niet gelijk is aan de omstandigheden waarin een mondige prostitué(e) in Nederland pleegt te verkeren', $5^{8}$

De memorie van toelichting spreekt in dit verband van een objectivering van het bestanddeel misbruik, waarmee bescherming wordt geboden aan personen die in een uitbuitingssituatie werkzaam zijn. Het bestanddeel 'misbruik van uit feitelijke verhoudingen voortvloeiend overwicht' is dus gekoppeld aan de uitbuitingssituatie. ${ }^{59}$ Met het begrip uitbuitingssituatie wordt nader aangeduid wat met het misbruik wordt bedoeld. Een uitbuitingssituatie doet zich volgens de wetgever al snel voor ten aanzien van personen die uit het buitenland afkomstig zijn, personen die verslaafd zijn aan verdovende middelen en zeer jonge personen. ${ }^{60}$ Voorts moet worden gedacht aan schulden, aangegaan om naar Nederland te komen ${ }^{6 \mathrm{r}}$ en - meer in het algemeen - aan het niet kunnen beschikken over eigen financiële middelen of over een paspoort of een geldig visum. Ten aanzien van vrouwen uit derdewereldlanden die in Nederland in de prostitutie worden gebracht, wordt opgemerkt dat met verwijzing naar hun positie in het land van herkomst veelal zal kunnen worden aangetoond dat sprake is van misbruik van uit feitelijke verhoudingen voortvloeiend overwicht. ${ }^{62}$ Anders gezegd: prostituees afkomstig uit derdewereldlanden verkeren volgens de wetgever vrijwel per definitie in een uitbuitingssituatie. Het misbruik van uit feitelijke verhoudingen voortvloeiend overwicht moet volgens de wetgever uit de omstandigheden worden afgeleid:

'Een uit een ontwikkelingsland afkomstig persoon of een aan verdovende middelen
verslaafde verkeert meestal niet in een situatie waarin een onafhankelijke zelfstan-
dige opstelling mogelijk is, vergelijkbaar met de opstelling van een mondige Neder-
landse prostitué(e). Met het woord mondig - elders in deze memorie wordt ook het
woord volwassen gebruikt - wordt gedoeld op een zekere rijpheid die de betrokkene
in staat stelt de gevolgen van zijn handelingen te overzien en zelfstandig beslissingen
te nemen. ${ }^{63}$

De 'mondigheid' heeft volgens de wetgever derhalve betrekking op de persoonlijke omstandigheden van de prostituee: omstandigheden die maken dat de prostituee

58 Kamerstukken II ig88/89, 2I 027, nr. 3, p. 3.

59 Zie ook Kamerstukken II I990/9I, 2I 027, nr. 5, p. 3: "Het woord "uitbuitingssituatie" komt niet in de delictsomschrijvingen (...) voor maar wordt in de memorie van toelichting gebruikt ter verduidelijking van het begrip "misbruik van uit feitelijke verhoudingen voortvloeiend overwicht" in die bepaling.'

6o Kamerstukken II I988/89, 2I 027, nr. 3, p. 4 en Kamerstukken II I990/9I, 2I 027, nr. 5, p. 3.

6 I Kamerstukken II I990/9I, 2I 027, nr. 5, p. 3: 'Daarbij kan onder meer worden gedacht aan schulden, aangegaan om de reis naar Nederland te betalen. De afbetalingsverplichting kan van dien aard zijn dat de zich prostituerende gedwongen is zich te blijven prostitueren.'

62 Kamerstukken II I990/9I, 2I 027, nr. 5, p. 3.

63 Kamerstukken II I988/89, 2I 027, nr. 3, p. 8. Overigens wordt in deze passage gesproken over 'een mondige Nederlandse prostituée' in plaats van 'mondige prostituée in Nederland'. Dat moet een verschrijving zijn geweest. In beginsel is mondigheid immers niet het exclusieve terrein van een Nederlandse prostituee. 
zich mondig kan opstellen. ${ }^{64}$ Volstrekt eenduidig is de wetgever op dit punt evenwel niet. Zo wordt elders in de wetsgeschiedenis het geobjectiveerde bestanddeel 'misbruik van uit feitelijke verhoudingen voortvloeiend overwicht' ook gekoppeld aan de arbeidsomstandigheden van de prostituee. Het aantreffen van een prostituee in arbeidsomstandigheden die niet voldoen aan de minimumeisen die in het vergunningenbeleid zullen worden ontwikkeld, duidt eveneens op een uitbuitingssituatie. ${ }^{65}$ De wetgever staat voor ogen dat door het vergunningenstelsel een objectieve maatstaf kan worden verkregen waaraan kan worden getoetst of sprake is van uitbuiting. De door de wetgever gegeven interpretatie van het bestanddeel lijkt evenwel toch zo te moeten worden begrepen dat het vooral ziet op persoonlijke omstandigheden die maken dat betrokkene in een situatie verkeert waarin de keuzevrijheid ontbreekt of de mogelijkheid tot het maken van een bewuste keuze is beperkt. ${ }^{66}$

Op grond van het voorgestelde artikel 250 ter lid I, onderdeel $2^{\circ}, \mathrm{Sr}$ is tevens aan mensenhandel schuldig:

'degene die een persoon aanwerft, medeneemt of ontvoert met het oogmerk die persoon in een ander land in de prostitutie te brengen'. ${ }^{67}$

Deze strafbare gedraging viel onder de strafbaarstelling van vrouwenhandel in artikel 25oter Sr zoals geïntroduceerd door de Wet Bestrijding van Zedeloosheid, maar wordt thans expliciet uitgeschreven. De bepaling vloeit voort uit het eerder besproken verdrag van 1933 . Uitvoering van deze verdragsverplichting noodzaakt de wetgever tot het onderscheiden van binnenlandse en buitenlandse handel. De bepaling wordt een vreemde eend in de bijt van de strafbaarstelling van mensenhandel. Immers, anders dan bij de strafbaarstelling van het tot prostitutie brengen of in de prostitutie doen belanden, is hier voor strafbaarheid inzake aanwerven het gebruik van ongeoorloofde middelen niet vereist. Door erop te wijzen dat het om vrij complexe gedragingen gaat die niet gemakkelijk kunnen worden aangetoond en de bepaling dus in de praktijk weinig zal kunnen worden toegepast, schrijft de wet-

64 Vgl. de conclusie van AG Knigge bij HR 27 oktober 2009, LJN: BI7099, p. I8.

65 Zie bijv. Kamerstukken II I990/9I, 2I 027, nr. 8, p. I: door de minister van Justitie wordt gewezen op het feit dat de aan een vergunning voor exploitatie verbonden voorschriften betrekking hebben op de werkomstandigheden van de prostituee zoals inrichting, verwarming en ventilatie van de werkruimte, aanwezigheid van sanitair en dergelijke. In dit verband wordt vervolgens opgemerkt: 'Door de vergunningstelsels zullen zich op dat terrein opvattingen ontwikkelen betreffende minimumeisen waaraan moet worden voldaan, wil sprake zijn van een aanvaardbare vorm van exploitatie van prostitutie. Een exploitant die er niet voor zorgt dat in zijn prostitutiebedrijf aan die minimumeisen wordt voldaan, schept een uitbuitingssituatie en maakt op deze wijze misbruik van uit feitelijke verhoudingen voortvloeiend overwicht. Hij pleegt dus het misdrijf, omschreven in artikel 25obis, eerste lid, onder I ${ }^{\circ}, \mathrm{Sr}(. .$.$) .'$

66 Kamerstukken II I988/89, 2I 027, nr. 3, p. 8.

67 Kamerstukken II I99I/92, 2I 027, nr. 9 (gewijzigd voorstel van wet). In het oorspronkelijk ingediende wetsvoorstel was het bestanddeel 'in een ander land' niet opgenomen. Het 'in een ander land' ziet zowel op import als export (Handelingen II, 2I mei I982, 8I-4980). 
gever deze strafbaarstelling - ten onrechte - enigszins weg. ${ }^{68}$ Het betreft volgens minister Hirsch Ballin een aanvulling op de strafbaarstelling van gedragingen, ondernomen onder aanwending van ongeoorloofde middelen, waardoor een ander tot prostitutie wordt gebracht of kan worden gebracht. ${ }^{69}$ De bepaling heeft volgens de minister in het samenstel van bepalingen gericht tegen mensenhandel een nuttige aanvullende waarde. Die waarde lijkt vooral te zijn gelegen in het feit dat het bewijs van het gebruik van ongeoorloofde middelen niet behoeft te worden geleverd..$^{\circ}$ Uitgaande van de fictie dat buitenlandse vrouwen per definitie in een uitbuitingssituatie verkeren, vormt de bepaling een nuttig vangnet.

Het feit dat in deze bepaling het uitgangspunt van aantasting van de keuzevrijheid wordt losgelaten - hetgeen zich moeizaam verhoudt tot de uitgangspunten van het Nederlandse prostitutiebeleid - zal nadien een weerkerend onderwerp van discussie in de wetsgeschiedenis worden. De pijn zit vooral in het begrip 'aanwerven'; in 'medenemen' en 'ontvoeren' lijkt onvrijwilligheid besloten te zitten.

Bij nota van wijziging wordt in artikel $250 t e r$ Sr ten aanzien van minderjarigen in een speciale strafbepaling voorzien..$^{71}$ Ter bescherming van minderjarigen neemt de wetgever tot uitgangspunt dat bij hen van een vrijwillige keuze voor prostitutie geen sprake kan zijn..$^{2}$ Om die reden is bij een minderjarig slachtoffer het gebruik van ongeoorloofde middelen geen vereiste voor strafbaarheid. Met betrekking tot minderjarigen wordt een uitbuitingssituatie dus als vaststaand aangenomen: uitbating van prostitutie door minderjarigen is zonder meer strafbaar.

De overige bepalingen in het gewijzigde artikel 25oter Sr, die voornamelijk verband houden met strafverzwarende omstandigheden, blijven hier verder buiten beschouwing.

\subsubsection{Intermezzo: politieke perikelen rondom de opheffing van het bordeelverbod}

Kort voor de mondelinge behandeling van wetsvoorstel 2I 027 in de Tweede Kamer wordt door minister Hirsch Ballin met een tweede nota van wijziging het in wetsvoorstel I8 202 voorgestelde artikel 25obis lid I Sr ingrijpend gewijzigd. Wetsvoorstel 2I 027 omvat daarmee naast een aanscherping van artikel 250 ter $\mathrm{Sr}$ in feite een geheel nieuw artikel 25obis Sr terzake exploitatie van prostitutie. ${ }^{73}$ De in wetsvoorstel 2I 027 voorgestelde wijziging van wetsvoorstel I8 202 krijgt daarmee het karakter van een novelle. De voorgestelde wijziging van artikel $250 \mathrm{bis} \mathrm{Sr}$ is tweeledig. Als misdrijfworden strafbaar gesteld: (I) het handelen in strijd met een bij gemeentelijke verordening gegeven verbod op exploitatie van prostitutie (waarmee de mogelijkheid van een lokaal bordeelverbod wordt geschapen) respectievelijk

68 Kamerstukken II I988/89, 2I 027, nr. 3, p. 9: 'De bepaling heeft derhalve een beperkte betekenis.'

69 Kamerstukken II I990/9I, 2I 027, nr. 5, p. I2.

70 Handelingen II, 2I mei I992, 8I-4980.

7I Kamerstukken II I990/9I, 2I 027, nr. 6.

72 Kamerstukken II I990/9I, 2I 027, nr. 5, p. 4.

73 Kamerstukken II I990/9I, 2I 027, nr. Io. 
de exploitatie van prostitutie zonder een bij gemeentelijke verordening vereiste vergunning, en (2) de exploitatie van prostitutie van personen op wie de dan geldende Wet arbeid buitenlandse werknemers van toepassing is. Laatstgenoemd voorstel berust op de volgende overwegingen, waaruit kan worden afgeleid dat - in elk geval in de ogen van de minister van Justitie - prostituees afkomstig uit derdewereldlanden vrijwel per definitie in een uitbuitingssituatie verkeren:

'Personen die hier te lande zonder tewerkstellingsvergunning werkzaam kunnen zijn, valt in elk geval feitelijk niet te beletten zich voor prostitutie beschikbaar te stellen. Het toestaan en van overheidswege eraan meewerken dat personen, met name afkomstig uit ontwikkelingslanden, in een prostitutiebedrijf worden geëxploiteerd, is echter niet aanvaardbaar. Dit zou immers het risico aanzienlijk vergroten dat personen die zijn aangeworven in het buitenland dan wel ingevolge misbruik van uit feitelijke verhoudingen voortvloeiend overwicht of misleiding naar Nederland zijn gekomen, dus personen die slachtoffers zijn van mensenhandel, in een prostitutiebedrijf worden geëxploiteerd. ${ }^{74}$

De door minister Hirsch Ballin in wetsvoorstel 2I 027 opgenomen wijzigingen van artikel 25obis Sr worden door de Tweede Kamer aanvaard. Vervolgens worden door de Eerste Kamer het reeds aanhangige wetsvoorstel I8 202 en wetsvoorstel 2I 027 gezamenlijk behandeld. Bij die behandeling staan de bij tweede nota van wijziging in wetsvoorstel 2I 027 gedane voorstellen centraal. Voor een meerderheid van de Eerste Kamer blijken die wijzigingsvoorstellen niet aanvaardbaar. De bezwaren houden in het kort het volgende in. De omstandigheid dat een gemeente de facto kan uitmaken of exploitatie van prostitutie als misdrijf strafbaar is, zou leiden tot een territoriaal gedifferentieerd misdrijvenstrafrecht en wordt in strijd geacht met artikel Io7 van de Grondwet (het zogenoemde codificatieartikel). Het absolute verbod op exploitatie van prostitutie van personen van buiten de Europese Unie zou discriminerend werken, en bovendien leiden tot een vlucht naar de illegaliteit. ${ }^{75}$

Minister Hirsch Ballin stelt zich evenwel op het standpunt dat hij wetsvoorstel I8 202 alleen kan verdedigen in combinatie met wetsvoorstel 2I 027, omdat daarin de hier vermelde en voor hem essentiële wijzigingen van artikel 25obis Sr zijn ondergebracht. Het in wetsvoorstel I8 202 voorgestelde artikel 25obis Sr wil hij zonder die wijzigingen niet voor zijn verantwoording nemen. Vanwege de onvoldoende steun voor de in wetsvoorstel 2I 027 voorgestelde wijziging van artikel 25obis Sr ziet hij zich uiteindelijk genoodzaakt om wetsvoorstel I8 202 in te trekken. ${ }^{7}$ Aangezien de in wetsvoorstel 21 027 opgenomen wijziging van artikel 25obis $\mathrm{Sr}$ een novelle was op het in wetsvoorstel I8 202 voorgestelde artikel 25obis Sr, komt door intrekking van wetsvoorstel I8 202 de grondslag voor een nieuw artikel 250 bis Sr te ontbreken.

74 Kamerstukken II I99I/92, 2I 027, nr. Io, p. 2 en 3.

75 Zie daarover R.H. Haveman, 'Strafbare exploitatie van prostitutie, een vreemde eend in de bijt van het recht', NJB 29 april I993, afl. I7, p. 630 e.v.

76 Kamerstukken II I993/94, I8 202, nr. I27. 
De artikelen 25obis en 432 Sr blijven als gevolg van de intrekking van wetsvoorstel I8 202 dan ook vooralsnog gehandhaafd. Wel kan het resterende en onomstreden gedeelte van wetsvoorstel 2I 027 - de aanscherping van de strafbaarstelling van mensenhandel in artikel 25oter $\mathrm{Sr}$ - door de Eerste Kamer worden aanvaard. ${ }^{77} \mathrm{De}$ gewijzigde strafbaarstelling van mensenhandel treedt op I februari 1994 in werking. Zij luidt:

'I. Als schuldig aan mensenhandel wordt gestraft hetzij met gevangenisstraf van ten hoogste zes jaren en geldboete van de vijfde categorie, hetzij met één van deze straffen: $I^{\circ}$. degene die een ander door geweld of een andere feitelijkheid of door bedreiging met geweld of een andere feitelijkheid dan wel door misbruik van uit feitelijke verhoudingen voortvloeiend overwicht of door misleiding tot prostitutie brengt, dan wel onder voornoemde omstandigheden enige handeling onderneemt waarvan hij of zij weet of redelijkerwijs moet vermoeden dat die ander daardoor in de prostitutie belandt;

$2^{\circ}$. degene die een persoon aanwerft, medeneemt of ontvoert met het oogmerk die persoon in een ander land in de prostitutie te brengen;

$3^{\circ}$. degene die een ander tot prostitutie brengt, dan wel ten aanzien van een ander enige handeling onderneemt waarvan hij of zij weet of redelijkerwijs moet vermoeden dat die ander daardoor in de prostitutie belandt, indien die ander minderjarig is.

2. Hetzij met gevangenisstraf van ten hoogste acht jaren en geldboete van de vijfde categorie, hetzij met één van deze straffen wordt gestraft:

$I^{\circ}$. mensenhandel door twee of meer verenigde personen;

$2^{\circ}$. mensenhandel ten aanzien van een persoon die de leeftijd van zestien jaren nog niet heeft bereikt;

$3^{\circ}$. mensenhandel, indien geweld of een andere feitelijkheid als bedoeld in het eerste lid, zwaar lichamelijk letsel ten gevolge heeft.

3. Mensenhandel door twee of meer verenigde personen onder de omstandigheden, bedoeld in het tweede lid, onder $2^{\circ}$ en $3^{\circ}$, wordt gestraft hetzij met gevangenisstraf van ten hoogste tien jaren en geldboete van de vijfde categorie, hetzij met één van deze straffen.'

\subsubsection{Wetsuoorstel 25437}

Met de intrekking van wetsvoorstel I8 202 is de opheffing van het bordeelverbod niet van de baan. Het Paarse kabinet onderneemt een nieuwe poging en onder verantwoordelijkheid van minister van Justitie Sorgdrager wordt bij koninklijke boodschap van I juli 1997 het wetsvoorstel tot opheffing van het algemeen bordeelverbod aan de Tweede Kamer aangeboden..$^{7}$ Dit wetsvoorstel bouwt voort op de eerdere wetsvoorstellen I8 202 en 2I 027, maar zonder de elementen waartegen een meerderheid van de Eerste Kamer overwegende bezwaren had. Het wetsvoorstel voorziet in afschaffing van het in artikel 25obis Sr neergelegde bordeelverbod, onder

77 Wet van 9 december 1993 (Stb. 679), inwerking getreden op I februari 1994 .

78 Zie hierover J.J. Wiarda, 'De wetgeving inzake de opheffing van het algemeen bordeelverbod', AA (2000) 9, p. 653-658. 
gelijktijdige (aanscherping van de) strafbaarstelling van vormen van exploitatie van prostitutie waarbij geweld, misbruik of misleiding dan wel minderjarigen zijn betrokken.

Voorgesteld wordt een nieuw artikel $250 \mathrm{~S} \mathrm{Sr}$ dat in de plaats komt van de artikelen 25 obis $\mathrm{Sr}$ (het bordeelverbod, het beroepsmatig bevorderen van ontucht door anderen met derden), 25oter (de strafbaarstelling van mensenhandel) en 432 , onderdeel $3^{\circ}$, Sr (de strafbaarstelling van het souteneurschap). Handel en ontoelaatbare exploitatie komen daarmee in één artikel te staan. Het begrip mensenhandel - dat als kwalificatie van de in artikel 25oter Sr strafbaar gestelde gedragingen werd genoemd - wordt niet in het artikel opgenomen. Vermoedelijk houdt dat verband met de reikwijdte van de bepaling. Kennelijk worden de onderdelen die zien op ongeoorloofd souteneurschap en ongeoorloofde exploitatie van prostitutie op dat moment niet als mensenhandel gezien. Voor zover hier van belang luidt het artikel als volgt:

\section{'Artikel $250 \mathrm{a}$}

I. Met gevangenisstraf van ten hoogste zes jaren of geldboete van de vijfde categorie wordt gestraft:

$I^{\circ}$. degene die een ander door geweld of een andere feitelijkheid of door bedreiging met geweld of een andere feitelijkheid dwingt dan wel door misbruik van uit feitelijke verhoudingen voortvloeiend overwicht of door misleiding beweegt zich beschikbaar te stellen tot het verrichten van seksuele handelingen met een derde tegen betaling, dan wel onder voornoemde omstandigheden enige handeling onderneemt waarvan hij of zij weet of redelijkerwijs moet vermoeden dat die ander zich daardoor tot het verrichten van die handelingen beschikbaar stelt;

$2^{\circ}$. degene die een persoon aanwerft, medeneemt of ontvoert met het oogmerk die persoon in een ander land ertoe te brengen zich beschikbaar te stellen tot het verrichten van seksuele handelingen met een derde tegen betaling;

$3^{\circ}$. degene die een ander ertoe brengt zich beschikbaar te stellen tot het verrichten van seksuele handelingen met een derde tegen betaling, dan wel ten aanzien van een ander enige handeling onderneemt waarvan hij of zij weet of redelijkerwijs moet vermoeden dat die ander zich daardoor tot het verrichten van die handelingen beschikbaar stelt, terwijl die ander minderjarig is;

$4^{\circ}$. degene die opzettelijk voordeel trekt uit seksuele handelingen van een ander met een derde tegen betaling, terwijl hij weet of redelijkerwijs moet vermoeden dat die ander zich onder de onder $\mathrm{I}^{\circ}$ genoemde omstandigheden beschikbaar stelt tot het plegen van die handelingen;

$5^{\circ}$. degene die opzettelijk voordeel trekt uit seksuele handelingen van een ander met een derde tegen betaling, indien die ander minderjarig is;

$6^{\circ}$. degene die een ander door geweld of een andere feitelijkheid of door bedreiging met geweld of een andere feitelijkheid dwingt dan wel door misbruik van uit feitelijke verhoudingen voortvloeiend overwicht of door misleiding beweegt hem of haar uit de opbrengst van zijn of haar seksuele handelingen met een derde te bevoordelen.

(...)' 
Artikel 250a lid I, onderdeel I, Sr komt vrijwel geheel overeen met artikel 25oter lid I, onderdeel I ${ }^{\circ}$, Sr. Daarin zit zowel het element van het iemand brengen in de situatie waarin die persoon zich prostitueert als het houden in die situatie. ${ }^{79}$ Artikel 250 lid I, onderdelen $2^{\circ}$ en $3^{\circ}$, Sr zijn ontleend aan artikel 25oter lid I, onderdelen $2^{\circ}$ en $3^{\circ}$. Nieuw zijn de in artikel 250 a lid I, onderdelen $4^{\circ}$ en $5^{\circ}$, Sr opgenomen strafbepalingen, waarin strafbaar wordt gesteld degene die opzettelijk voordeel trekt uit seksuele handelingen van een ander met een derde tegen betaling ${ }^{80}$, terwijl hij weet of behoort te weten dat die ander zich onvrijwillig prostitueert, dan wel indien die ander minderjarig is. ${ }^{8 \mathrm{I}}$ Daarmee is, zij het in sterk gewijzigde vorm, de strafbaarstelling inzake souteneurschap uit artikel 432 , onderdeel $3^{\circ}$, Sr behouden in artikel $250 a \mathrm{Sr}$.

Volgens de memorie van toelichting zijn deze strafbepalingen bedoeld om strafrechtelijk te kunnen optreden tegen achtergronddaders van wie niet zeker is dat vervolging op grond van strafbare deelneming aan de in onderdeel $1^{\circ}$ of $3^{\circ}$ strafbaar gestelde gedragingen mogelijk is. ${ }^{82}$

Artikel 250 a lid I, onderdeel $6^{\circ}$, Sr is bij nota van wijziging aan het wetsvoorstel toegevoegd. ${ }^{8}$ Het voorstel komt voort uit de constatering door de Tweede Kamer dat het oorspronkelijk voorgestelde artikel $250 a$ Sr niet voorziet in de mogelijkheid tot optreden tegen uitbuiting in het geval van exploitatie van vrijwillige prostitutie. ${ }^{84}$ In reactie daarop wordt in onderdeel $6^{\circ}$ de onvrijwillige afdracht van uit prostitutie afkomstige gelden strafbaar gesteld. Het gaat dus om de gedwongen afgifte van de opbrengst van prostitutie, zonder dat sprake behoeft te zijn van onvrijwillige prostitutie. $^{85}$ De formulering van de bepaling komt inhoudelijk overeen met de

79 Kamerstukken II I996/97, 25 437, nr. 3, p. 9.

80 In artikel 25oter Sr werd het begrip 'prostitutie' gehanteerd. In artikel 2500 Sr wordt dat begrip vervangen door de omschrijving 'het zich beschikbaar stellen tot het verrichten van seksuele handelingen met een derde tegen betaling.' (zie Kamerstukken II I996/97, 25 437, nr. 3, p. 9).

8I Ten aanzien van onderdeel $5^{\circ}$, waarin het opzettelijk voordeel trekken uit seksuele handelingen van een minderjarige met een derde strafbaar wordt gesteld, wordt in de memorie van toelichting de vraag opgeworpen of in het kader van de bestrijding van kinderprostitutie tevens de klant van een minderjarige prostituee strafbaar zou moeten worden gesteld. De minister van Justitie stelt zich in eerste instantie terughoudend op en ziet onvoldoende aanleiding voor een uitzondering op de regel dat het plegen van seksuele handelingen met een persoon vanaf zestien jaren in beginsel niet strafbaar is (Kamerstukken II I996/97, 25 437, nr. 3, p. Io). Tijdens de behandeling van het wetsvoorstel door de Tweede Kamer wordt evenwel het amendement-Barth, dat voorziet in een nieuw artikel $248 \mathrm{~b} \mathrm{Sr}$, waarin het plegen van ontucht met een minderjarige prostituee van zestien en zeventien jaar strafbaar wordt gesteld, aanvaard en in het Wetboek van Strafrecht opgenomen (Kamerstukken II I998/99, 25 437, nr. 9). Vermelding verdient dat bij gelegenheid van dit wetsvoorstel tevens het klachtvereiste is komen te vervallen voor de gevallen dat een persoon seksuele handelingen pleegt met een minderjarige tussen twaalf en zestien jaren die zich beschikbaar stelt tot het tegen betaling verrichten van die handelingen (zie Kamerstukken II I996/97, 25 437, nr. 3, p. Io en II).

82 Kamerstukken II I996/97, 25 437, nr. 3, p. 9.

83 Kamerstukken II I997/98, 25 437, nr. 6 (nota van wijziging).

84 Kamerstukken II I997/98, 25 437, nr. 4 (verslag), p. I4.

85 Kamerstukken II I997/98, 25 437, nr. 5 (nota naar aanleiding van het verslag), p. 22-23. In de toelichting op de bepaling wordt opgemerkt dat bij dit feitencomplex ook kan worden opgetreden op grond van de artikelen $317 \mathrm{Sr}$ (afdreiging) en $284 \mathrm{Sr}$ (dwang). Een afzonderlijke bepaling wordt evenwel wenselijk geacht omdat bij de voormelde delicten de elementen misbruik van uit 
delictsomschrijving van strafbare exploitatie van prostitutie in artikel 25obis Sr, zoals die oorspronkelijk door minister Korthals Altes bij nota van wijziging was voorgesteld in wetsvoorstel I8 202 (zie de bespreking van dat wetsvoorstel hiervoor). ${ }^{86}$

Zoals hiervoor vermeld, is in artikel $250 \mathrm{a}$ lid I, onderdeel $2^{\circ}$, Sr de - veelbesproken uit het verdrag van 1933 voortvloeiende verplichting tot strafbaarstelling van het aanwerven, medenemen of ontvoeren zonder gebruik van ongeoorloofde middelen opgenomen. Het aanwerven van een persoon voor prostitutie uit het buitenland (ook de Europese Unie) is dus strafbaar, ook al stemt de aangeworven persoon daarmee in. Deze bepaling wordt tijdens de parlementaire behandeling van het wetsvoorstel opnieuw ter discussie gesteld. Gewezen wordt op de inconsistentie tussen de strafbaarstelling van aanwerving op basis van vrijwilligheid en het voorstel tot opheffing van het bordeelverbod, waardoor exploitatie van vrijwillige prostitutie niet langer strafbaar zal zijn. Bij amendement wordt getracht deze inconsistentie weg te nemen. ${ }^{87}$ De minister van Justitie - dat is minister Korthals, de opvolger van minister Sorgdrager - reageert met erop te wijzen dat de tekst van de bepaling na de voorgestelde amendering strijdig zal zijn met het verdrag en dat aanvaarding van het amendement aldus zal moeten leiden tot opzegging van het verdrag. Dat laatste wordt onwenselijk geacht, omdat Nederland daarmee in het kader van de bestrijding van mensenhandel internationaal een verkeerd signaal zou afgeven.$^{88}$ De bepaling overleeft ook deze aanval en blijft ook nu behouden.

\subsubsection{Wetsuoorstel 27745}

Bij gelegenheid van het bij koninklijke boodschap van I8 mei 20or ingediende wetsvoorstel tot partiële wijziging van de zedelijkheidswetgeving wordt het bereik van artikel 250a Sr uitgebreid tot uitbuiting van personen voor andere seksuele handelingen dan prostitutie. Daartoe is in artikel 250a Sr het verrichten van seksuele

feitelijke verhoudingen voortvloeiend overwicht en misleiding ontbreken en de strafbedreiging van artikel $284 \mathrm{Sr}$ onvoldoende wordt geacht.

86 Kamerstukken II I985/86, I8 202, nr. 6. Die bepaling strekte toen tot schrapping van het bordeelverbod en tot vervanging van de in hetzelfde wetsvoorstel oorspronkelijk als artikel $250 t e r$ Sr voorgestelde strafbaarstelling inzake souteneurschap. De bepaling richtte zich zowel tot de souteneur als tot de exploitant van een prostitutiebedrijf.

87 In het amendement-Halsema wordt voorgesteld het woord 'aanwerft' te schrappen (Kamerstukken II I998/99, 25 437, nr. II). Vervolgens wordt in het gewijzigd amendement-Halsema voorgesteld voor het woord 'aanwerft' het woord 'bedrieglijk' in te voegen (Kamerstukken II I998/99, 25 437, nr. I5).

88 Kamerstukken II I998/99, 25 437, nr. I7, p. 4-5. De minister van Justitie wijst in de desbetreffende brief tevens op de onderhandelingen over het verdrag tegen transnationale georganiseerde misdaad die op dat moment een aanvang hebben genomen en waarbij ook aandacht is voor mensenhandel. Het ware volgens de minister beter om de uitkomst van die onderhandelingen af te wachten alvorens te bezien of de wetgeving inzake mensenhandel wijziging behoeft. De desbetreffende onderhandelingen zullen uiteindelijk mede resulteren in het Protocol inzake de preventie, bestrijding en bestraffing van mensenhandel, in het bijzonder vrouwenhandel en kinderhandel (Palermo Protocol). 
handelingen met een derde vervangen door: met of voor een derde. ${ }^{89}$ Aldus wordt met een relatief kleine wijziging het bereik van de strafbaarstelling van mensenhandel sterk vergroot. De wijziging strekt mede tot uitvoering van het ILO-Verdrag inzake het verbod en de onmiddellijke actie voor de uitbanning van de ergste vormen van kinderarbeid (Trb. 2000, 52). De wetgever heeft er evenwel voor gekozen om de uitbreiding niet te beperken tot kinderen, maar ook de uitbuiting van volwassenen te verbreden tot andere vormen van seksuele dienstverlening dan prostitutie..$^{\circ \circ}$

Voorts verdient vermelding dat bij gelegenheid van dit wetsvoorstel door een amendement van de Tweede Kamer het vereiste van dubbele strafbaarheid wordt afgeschaft voor zedenmisdrijven, daaronder ook begrepen artikel 250a Sr, gepleegd tegen kinderen in het buitenland door een Nederlander of een vreemdeling met een vaste woon- of verblijfplaats in Nederland..$^{91}$ Het betreft de eerste verruiming van extraterritoriale rechtsmacht terzake mensenhandel in een reeks (zie nader hoofdstuk 5.I).

\subsubsection{Internationale ontwikkelingen: rechtsinstrumenten ter bestrijding van mensenhandel}

Na een periode van windstilte volgen vanaf de jaren negentig de internationale ontwikkelingen elkaar weer in hoog tempo op. De bestrijding van mensensmokkel en mensenhandel krijgt aandacht op het niveau van de Verenigde Naties, de Raad van Europa en de Europese Unie..$^{92}$ Op het niveau van de Verenigde Naties komt op I5 november 2000 te New York het Verdrag tegen transnationale georganiseerde criminaliteit tot stand (Trb. 200I, 68), met gelijktijdig het bijbehorende Protocol inzake de preventie, bestrijding en bestraffing van mensenhandel, in het bijzonder vrouwenhandel en kinderhandel (hierna: Palermo Protocol) (Trb. 200I, 69).

De delictsomschrijving van mensenhandel in het Palermo Protocol is opgebouwd uit de bestanddelen handeling, middel (dwang in ruime zin) en doel van uitbuiting. Artikel 3 van het Palermo Protocol geeft de definitie die later ook in andere instrumenten tot uitgangspunt zal worden genomen, en luidt in de Nederlandse vertaling:

'Voor de toepassing van dit Protocol wordt verstaan onder:

a. "mensenhandel": het werven, vervoeren, overbrengen van en het bieden van onderdak aan of het opnemen van personen, door dreiging met of gebruik van geweld of andere vormen van dwang, ontvoering, bedrog, misleiding, machtsmisbruik of misbruik van een kwetsbare positie of het verstrekken of in ontvangst nemen van

89 Kamerstukken II 2000/oI, 27 745, nrs. I-2; Wet van I3 juli 2002 (Stb. 2002, 388), in werking getreden op I oktober 2002.

90 Kamerstukken II 2000/oI, 27 745, nr. 3, p. 7 en I2.

9I Zie het aanvaarde amendement-Barth (Kamerstukken II 200I/02, 27 745, nr. 7), waarmee in hoofdzaak wordt beoogd kindersekstoerisme effectiever te kunnen bestrijden.

92 Zie voor een beschrijving van de door deze organisaties op het terrein van de bestrijding van mensenhandel tot stand gebrachte rechtsinstrumenten A. Gallagher, 'Recent legal developments in the field of human trafficking: a critical review of the 2005 European Convention and related instruments', European Journal of Migration and Law 8 (2006), p. I63-I89. 
betalingen of voordelen teneinde de instemming van een persoon te verkrijgen die zeggenschap heeft over een andere persoon, ten behoeve van uitbuiting. Uitbuiting omvat mede: ten minste de uitbuiting van prostitutie van anderen of andere vormen van seksuele uitbuiting, gedwongen arbeid of diensten, slavernij of praktijken die vergelijkbaar zijn met slavernij, onderworpenheid of de verwijdering van organen;

b. de instemming van een slachtoffer van mensenhandel met de beoogde uitbuiting, bedoeld in onderdeel a van dit artikel, is irrelevant indien een van de in onderdeel a bedoelde middelen zijn gebruikt; (...)'

Van grote betekenis is de uitbreiding van het bereik van mensenhandel. Mensenhandel, zoals omschreven in het Palermo Protocol, omvat niet alleen vormen van seksuele uitbuiting, maar ook alle andere vormen van moderne slavernij en de verwijdering van organen. ${ }^{93}$ Artikel I van het EU-kaderbesluit inzake bestrijding van mensenhandel dat op I9 juli 2002 te Brussel tot stand komt, hanteert eveneens een ruime omschrijving van mensenhandel, zij het dat de verwijdering van organen daarvan geen onderdeel uitmaakt. Deze internationale instrumenten nopen tot wijziging van artikel $250 \mathrm{O} \mathrm{Sr}$, dat immers beperkt is tot strafbaarstelling van vormen van seksuele uitbuiting voor prostitutie en andere vormen van seksuele dienstverlening. ${ }^{94}$ De strafbaarstelling van mensenhandel moet worden verruimd tot andere vormen van uitbuiting. Mensenhandel moet uit de sfeer van uitsluitend seksuele uitbuiting worden gebracht.

\subsubsection{Wetsvoorstel 29291}

Bij koninklijke boodschap van I2 november 2003 wordt het voorstel van wet tot uitvoering van internationale regelgeving ter bestrijding van mensensmokkel en mensenhandel aan de Tweede Kamer aangeboden. ${ }^{95}$ Dit wetsvoorstel strekt tot uitvoering van een achttal rechtsinstrumenten van de Verenigde Naties ${ }^{9}$

93 Het feit dat het Palermo Protocol is verbonden aan het Verdrag tegen transnationale georganiseerde criminaliteit zou het vermoeden kunnen doen rijzen dat er een grensoverschrijdend aspect aan de gedraging dient te zitten. Artikel 34 lid 2 van het Verdrag verplicht evenwel tot strafbaarstelling van de omschreven gedragingen ongeacht hun grensoverschrijdend karakter. Artikel I lid 3 van het Protocol stelt vervolgens uitdrukkelijk dat de in het Protocol omschreven strafbare feiten moeten worden beschouwd als strafbare feiten ingevolge het Verdrag.

94 In dit verband verdient tevens vermelding het op I6 mei 2005 te Warschau in het kader van de Raad van Europa tot stand gekomen Verdrag inzake bestrijding van mensenhandel (Trb. 2006, 99) (zie ook hoofdstuk 2.2). Artikel 4 van dit verdrag hanteert eveneens de op het Palermo Protocol geënte definitie van mensenhandel, waardoor voor de goedkeuring van dit verdrag door Nederland geen wijziging van de delictsomschrijving nodig was. Wel is ter uitvoering van het verdrag een verruiming van extraterritoriale rechtsmacht terzake mensenhandel tot stand gebracht (Wet van 26 november 2009, Stb. 525) (zie nader hoofdstuk 5.I).

95 Kamerstukken II 2003/04, 29 29I, nrs. I-2.

96 Het betreft het op 25 mei 2000 te New York tot stand gekomen Facultatief Protocol inzake de verkoop van kinderen, prostitutie en kinderpornografie bij het Verdrag inzake de rechten van het kind (Trb. 200I, 63), het op I5 november 2000 te New York tot stand gekomen Verdrag tegen transnationale georganiseerde misdaad (Trb. 200I, 68), het op I5 november 2000 te New York tot stand gekomen Protocol inzake de preventie, bestrijding en bestraffing van mensenhandel, in het bijzonder vrouwenhandel en kinderhandel, tot aanvulling van het Verdrag tegen transnationale georganiseerde misdaad (Trb. 200I, 69), het op I5 november 2000 te New York tot stand 
respectievelijk de Europese Unie ${ }^{97}$ ter bestrijding van mensensmokkel, mensenhandel, uitbuiting van kinderen en kinderpornografie, waaronder het Palermo Protocol.

De brede omschrijving van mensenhandel in het Palermo Protocol heeft de wetgever bij de implementatie voor de keuze gesteld om te voorzien in een algemene strafbaarstelling van mensenhandel óf een onderscheid te maken tussen seksuele uitbuiting en overige uitbuiting. De wetgever kiest ervoor om alle vormen van mensenhandel in één strafbepaling op te nemen..$^{8}$ Daartoe wordt de inhoud van artikel $250 a \mathrm{Sr}$ opgenomen in een nieuwe algemene bepaling inzake mensenhandel, die wordt neergelegd in een nieuw artikel 273a Sr in de titel XVIII 'Misdrijven tegen de persoonlijke vrijheid'. Dat artikel is gedeeltelijk gemodelleerd naar artikel $250 \mathrm{a}$ $\mathrm{Sr}$. In het artikel worden aldus de nationale verworvenheden van artikel $250 \mathrm{O} \mathrm{Sr}$ en de implementatie van internationale verplichtingen samengevoegd en ineengesmeed. ${ }^{99}$ Het begrip mensenhandel doet opnieuw zijn intrede in het Wetboek van Strafrecht, nu als kwalificatie van alle in artikel 250a Sr strafbaar gestelde gedragingen. De keuze voor een verplaatsing van de zedentitel naar titel XVIII van het Wetboek van Strafrecht vindt haar grond in de uitbreiding van de strafbaarstelling met niet seksueel gerelateerde vormen van uitbuiting. ${ }^{100}$

Bij de totstandkoming van de nieuwe bepaling heeft de wetgever het delict mensenhandel in de memorie van toelichting als volgt omschreven:

'Mensenhandel is kort gezegd het dwingen - in ruime zin - van mensen om zich beschikbaar te stellen tot het verrichten van (seksuele) diensten of om eigen organen beschikbaar te stellen. (...) Mensenhandel is (gericht op) uitbuiting. Bij de strafbaarstelling van mensenhandel staat het belang van het individu steeds voorop. Dat belang is het behoud van zijn of haar lichamelijke en geestelijke integriteit en persoonlijke

gekomen Protocol tegen de smokkel van migranten over land, over de zee en in de lucht, tot aanvulling van het Verdrag tegen transnationale georganiseerde misdaad (Trb. 200I, 70).

97 Het betreft het op Ig juli 2002 te Brussel tot stand gekomen kaderbesluit van de Raad inzake bestrijding van mensenhandel (PbEG L 203), de op 28 november 2002 te Brussel tot stand gekomen richtlijn van de Raad tot omschrijving van de hulp bij illegale binnenkomst, illegale doorreis en illegaal verblijf ( $\mathrm{PbEG} \mathrm{L}$ 328), het op 28 november 2002 te Brussel tot stand gekomen kaderbesluit van de Raad tot versterking van het strafrechtelijk kader voor de bestrijding van de hulp bij illegale binnenkomst, illegale doorreis en illegaal verblijf ( $P b E G$ L 328) en het op 22 december 2003 te Brussel tot stand gekomen kaderbesluit van de Raad ter bestrijding van seksuele uitbuiting van kinderen en kinderpornografie (PbEU 2004, LI3).

98 Kamerstukken II 2003/04, 29 29I, nr. 3, p. I3 en Kamerstukken II 2003/04, 29 29I, nr. 7, p. 6. De vraag of met een algemene strafbaarstelling van mensenhandel de in de artikelen 274 tot en met 277 Sr neergelegde strafbepalingen inzake slavernij kunnen komen te vervallen, wordt door wetgever ontkennend beantwoord. Het Palermo Protocol is niet in de plaats gekomen van de verdragen inzake slavernij en slavenhandel. De strafbepalingen die aan de desbetreffende verdragen uitvoering geven, dienen te worden behouden.

99 Kamerstukken II 2003/04, 29 29I, nr. 3, p. I3; Kamerstukken II 2003/04, 29 29I, nr. 7, p. 7.

IOO Kamerstukken II 2003/04, 29 29I, nr. 3, p. I7. Overigens hebben we kunnen zien dat in de wetsgeschiedenis van de strafbaarstelling van mensenhandel al eerder de vraag werd opgeworpen of titel XVIII niet de meest geëigende plaats voor de strafbepaling is, zie noten 22 en 43 . 
vrijheid. De staat dient strafrechtelijke bescherming te bieden tegen aantasting van het recht op die integriteit en vrijheid. ${ }^{\text {ror }}$

De wetgever heeft zich bewust getoond van het feit dat door de verbreding van de reikwijdte van de strafbaarstelling zich vele verschillende - in ernst uiteenlopendeverschijningsvormen van mensenhandel kunnen voordoen. Volgens de memorie van toelichting geeft het voor artikel 273 a lid I Sr voorgestelde strafmaximum van zes jaar voor het gronddelict mensenhandel voldoende ruimte om rekening te houden met de in aard en ernst verschillende strafbaar gestelde gedragingen. Daarbij geeft de wetgever de rechtspraktijk als richtsnoer bij de straftoemeting mee dat uitbuiting waarbij de lichamelijke integriteit in het geding is, zoals bij seksuele uitbuiting en de verwijdering van organen, behoort tot de meest ernstige vorm van uitbuiting. ${ }^{\text {Io2 }}$

In de memorie van toelichting wordt erop gewezen dat de in het Palermo Protocol en het EU-kaderbesluit opgenomen omschrijving van mensenhandel anders is opgebouwd dan de omschrijving van seksuele uitbuiting in het dan geldende artikel $250 \mathrm{O}$ lid I, onderdeel I ${ }^{\circ}, \mathrm{Sr}$ - het een ander dwingen of bewegen tot het verrichten van seksuele handelingen met of voor een derde tegen betaling -, waarin de dwang direct gekoppeld is aan de uitbuiting. De internationale omschrijving van mensenhandel heeft primair betrekking op de activiteit van de mensenhandel. Die activiteiten zijn gericht op de verwezenlijking van het einddoel, de uitbuiting of de verwijdering van organen. De wetgever heeft die systematiek overgenomen in artikel 273a lid I, onderdeel $\mathrm{I}^{\circ}, \mathrm{Sr}^{103}$

In artikel 273 a lid 2 Sr wordt uitbuiting nader omschreven. Ook deze definitie volgt vrijwel volledig de tekst van de internationale instrumenten waaraan het wetsvoorstel uitvoering geeft (artikel 3, onder a, Palermo Protocol en artikel I, onder d, EUkaderbesluit). De wetgever heeft summier toegelicht wat onder de in deze definitie opgenomen begrippen moet worden verstaan:

'Uitbuiting bestaat ten minste uit een aantal met name genoemde vormen van uitbuiting: de uitbuiting van een ander in de prostitutie of andere vormen van seksuele uitbuiting, gedwongen of verplichte arbeid of diensten, slavernij of met slavernij of dienstbaarheid te vergelijken praktijken. Dat zijn alle vormen van moderne slavernij. Daarbij kan worden gedacht aan tewerkstelling onder dwang of het maken van misbruik van een afhankelijke positie van een persoon die onder de gegeven omstandigheden

\footnotetext{
IOI Kamerstukken II 2003/04, 29 29I, nr. 3, p. 2.

I02 Kamerstukken II 2003/04, 29 29I, nr. 3, p. I8. Overigens is de hoogte van de in artikel 273a Sr opgenomen strafmaxima tijdens de parlementaire behandeling van het wetsvoorstel wel onderwerp van discussie geweest. In het (niet aangenomen) amendement-Albayrak wordt voorgesteld om het algemeen strafmaximum voor het gronddelict mensenhandel te stellen op acht jaar en trapsgewijs te verhogen tot 20 jaar voor mensenhandel gepleegd onder de meest ernstige strafverzwarende omstandigheden (Kamerstukken II 2003/04, 29 29I, nr. Io). Recent heeft de wetgever alsnog in een vergelijkbare verhoging van de strafmaxima in artikel $273 \mathrm{f} \mathrm{Sr}$ voorzien (zie nader hoofdstuk 2.I.II).

I03 Kamerstukken II 2003/04, 29 29I, nr. 3, p. I8.
} 
redelijkerwijs geen andere keuze heeft dan in een toestand van uitbuiting te geraken. Als voorbeeld kan worden genoemd een extreem lange werkweek tegen onevenredig lage betaling onder slechte werkomstandigheden.' ${ }^{\text {104 }}$

Ten aanzien van de in de internationale instrumenten (artikel 3, onder b, Palermo Protocol, artikel I lid I, EU-kaderbesluit) opgenomen bepaling waarin tot uitdrukking wordt gebracht dat de instemming van het slachtoffer met de beoogde of bestaande uitbuiting niet relevant is, indien een van de in de delictsomschrijving genoemde dwangmiddelen is gebruikt, stelt de wetgever zich op het standpunt dat dit niet tot uitdrukkelijke wetgeving behoeft te leiden. ${ }^{105}$ De desbetreffende bepaling is dan ook niet in artikel 273a Sr geïmplementeerd.

In artikel $273 \mathrm{a} \mathrm{lid} \mathrm{I,} \mathrm{onderdeel} 2^{\circ}$, Sr wordt met dezelfde - op internationale leest geschoeide - systematiek als in onderdeel $\mathrm{I}^{\circ}$ de handel in kinderen strafbaar gesteld. Het gebruik van middelen is, zoals reeds in artikel 250ter Sr en daarna 250a Sr het geval was, voor strafbaarheid niet vereist. ${ }^{106}$ Artikel 273 a lid I, onderdelen $4^{\circ}$ tot en met $9^{\circ}$, zijn gebaseerd op artikel $250 \mathrm{a} \mathrm{Sr}$, met dien verstande dat de redactie op punten is gewijzigd in verband met de internationale delictsomschrijving en de verbreding van mensenhandel tot overige uitbuiting en de verwijdering van organen. Zo wordt in de onderdelen $4^{\circ}$ en $9^{\circ}$ - beide ontleend aan artikel $250 \mathrm{O} \mathrm{Sr}$ - verwezen naar de in onderdeel $I^{\circ}$ genoemde middelen, die op hun beurt zijn ontleend aan de internationale delictsomschrijving. Nieuw is daarbij bijvoorbeeld het middel 'misbruik van een kwetsbare positie'.

In artikel 273 a lid I, onderdeel $3^{\circ}$, Sr is artikel 250 a lid I, onderdeel $2^{\circ}$, Sr neergelegd. Het betreft de hiervoor besproken - uit het verdrag van 1933 voortgevloeide - strafbaarstelling van het grensoverschrijdend aanwerven van een persoon voor (sinds de vervanging van met door met of voor een derde) seksuele dienstverlening. In de memorie van toelichting wordt de keuze voor behoud van deze bepaling nog eens uiteengezet. Die toelichting houdt in dat aan de totstandkoming van het Palermo Protocol geen argumenten kunnen worden ontleend die wijzen op een gewijzigd inzicht ten aanzien van deze bepaling. Verder wordt verwezen naar de argumenten die eerder naar voren zijn gebracht ten faveure van handhaving van deze strafbepaling. De bepaling biedt volgens de wetgever nog steeds een nuttig en aanvullend instrument in de bestrijding van seksueel gerelateerde mensenhandel. ${ }^{\text {107 }}$ Tijdens de parlementaire behandeling van wetsvoorstel 29 29I staat deze bepaling niet meer ter discussie.

I04 Kamerstukken II 2003/04, 29 29I, nr. 3, p. I8.

I05 Kamerstukken II 2003/04, 29 29I, nr. 3, p. I9.

Io6 Het begrip 'minderjarige' wordt bij deze gelegenheid vervangen door 'persoon die de leeftijd van achttien jaren nog niet heeft bereikt'. Daarmee is strafrechtelijke bescherming van alle kinderen beter gewaarborgd. Het begrip minderjarige betreft kinderen, met uitzondering van personen van I6 en I7 jaar die getrouwd zijn (Kamerstukken II 2003/04, 29 29I, nr. 3, p. I6).

I07 Kamerstukken II 2003/04, 29 29I, nr. 3, p. 9. 
In de hier beschreven wetsgeschiedenis heeft de strafbaarstelling van mensenhandel haar huidige vorm, reikwijdte en strekking gekregen. Twee wijzigingen behoeven evenwel nog kort vermelding, alvorens we aanbelanden bij de huidige strafbaarstelling van mensenhandel.

Artikel 273a Sr is met ingang van I september 2006 vernummerd tot artikel $273 \mathrm{f} \mathrm{Sr}^{\mathrm{I}}{ }^{108}$ En ten slotte zijn met ingang van I juli 2009 de strafmaxima in artikel $273 \mathrm{f} \mathrm{Sr}$ verhoogd. ${ }^{109}$ Het strafmaximum voor het gronddelict mensenhandel is verhoogd van zes naar acht jaar. Het strafmaximum voor alle gekwalificeerde vormen van mensenhandel bedraagt thans ten minste twaalf jaar en loopt onder de meest ernstige omstandigheden op tot achttien jaar. Daarmee wordt volgens de memorie van toelichting de maatschappelijke herwaardering van de ernst van mensenhandel tot uitdrukking gebracht. Aan de verhoging van de strafmaxima lag mede de wens van het openbaar ministerie ten grondslag om in meer gevallen bij de vordering van voorlopige hechtenis de zogenoemde I2-jaars grond (artikel 67a lid 2, onder $\mathrm{I}^{\circ}$, Sv) op te kunnen voeren. ${ }^{\text {Io }}$ Met het strafmaximum van acht jaar voor het gronddelict mensenhandel is de mogelijkheid gecreëerd om tegen strafbare voorbereiding (artikel $46 \mathrm{Sr}$ ) van het misdrijf op te treden.

Artikel 273 fr luidt thans:

'I. Als schuldig aan mensenhandel wordt met gevangenisstraf van ten hoogste acht jaren of geldboete van de vijfde categorie gestraft:

$\mathrm{I}^{\circ}$. degene die een ander door dwang, geweld of een andere feitelijkheid of door dreiging met geweld of een andere feitelijkheid, door afpersing, fraude, misleiding dan wel door misbruik van uit feitelijke omstandigheden voortvloeiend overwicht, door misbruik van een kwetsbare positie of door het geven of ontvangen van betalingen of voordelen om de instemming van een persoon te verkrijgen die zeggenschap over die ander heeft, werft, vervoert, overbrengt, huisvest of opneemt, met het oogmerk van uitbuiting van die ander of de verwijdering van diens organen;

$2^{\circ}$. degene die een ander werft, vervoert, overbrengt, huisvest of opneemt, met het oogmerk van uitbuiting van die ander of de verwijdering van diens organen, terwijl die ander de leeftijd van achttien jaren nog niet heeft bereikt;

$3^{\circ}$. degene die een ander aanwerft, medeneemt of ontvoert met het oogmerk die ander in een ander land ertoe te bewegen zich beschikbaar te stellen tot het verrichten van seksuele handelingen met of voor een derde tegen betaling;

$4^{\circ}$. degene die een ander met een van de onder $I^{\circ}$ genoemde middelen dwingt of beweegt zich beschikbaar te stellen tot het verrichten van arbeid of diensten of zijn

Io8 Wet van I juni 2006 (Stb. 2006, 300).

Iog Wet van I2 juni 2009 (Stb. 2009, 245).

IIo Ook de Nationaal Rapporteur heeft zich uitgesproken voor verhoging van de strafmaxima voor mensenhandel, 'Vijfde rapportage van de Nationaal Rapporteur', BNRM, Den Haag, p. 20 (NRM 5). 
organen beschikbaar te stellen dan wel onder de onder $\mathrm{I}^{\circ}$ genoemde omstandigheden enige handeling onderneemt waarvan hij weet of redelijkerwijs moet vermoeden dat die ander zich daardoor beschikbaar stelt tot het verrichten van arbeid of diensten of zijn organen beschikbaar stelt;

$5^{\circ}$. degene die een ander ertoe brengt zich beschikbaar te stellen tot het verrichten van seksuele handelingen met of voor een derde tegen betaling of zijn organen tegen betaling beschikbaar te stellen dan wel ten aanzien van een ander enige handeling onderneemt waarvan hij weet of redelijkerwijs moet vermoeden dat die ander zich daardoor beschikbaar stelt tot het verrichten van die handelingen of zijn organen tegen betaling beschikbaar stelt, terwijl die ander de leeftijd van achttien jaren nog niet heeft bereikt; $6^{\circ}$. degene die opzettelijk voordeel trekt uit de uitbuiting van een ander;

$7^{\circ}$. degene die opzettelijk voordeel trekt uit de verwijdering van organen van een ander, terwijl hij weet of redelijkerwijs moet vermoeden dat diens organen onder de onder $\mathrm{I}^{\circ}$ bedoelde omstandigheden zijn verwijderd;

$8^{\circ}$. degene die opzettelijk voordeel trekt uit seksuele handelingen van een ander met of voor een derde tegen betaling of de verwijdering van diens organen tegen betaling, terwijl die ander de leeftijd van achttien jaren nog niet heeft bereikt;

$9^{\circ}$. degene die een ander met een van de onder $\mathrm{I}^{\circ}$ genoemde middelen dwingt dan wel beweegt hem te bevoordelen uit de opbrengst van diens seksuele handelingen met of voor een derde of van de verwijdering van diens organen.

2. Uitbuiting omvat ten minste uitbuiting van een ander in de prostitutie, andere vormen van seksuele uitbuiting, gedwongen of verplichte arbeid of diensten, slavernij en met slavernij of dienstbaarheid te vergelijken praktijken.

3. De schuldige wordt gestraft met gevangenisstraf van ten hoogste twaalf jaren of geldboete van de vijfde categorie, indien:

$I^{\circ}$. de feiten, omschreven in het eerste lid, worden gepleegd door twee of meer verenigde personen;

$2^{\circ}$. de persoon ten aanzien van wie de in het eerste lid omschreven feiten worden gepleegd, de leeftijd van zestien jaren nog niet heeft bereikt.

4. Indien een van de in het eerste lid omschreven feiten zwaar lichamelijk letsel ten gevolge heeft of daarvan levensgevaar voor een ander te duchten is, wordt gevangenisstraf van ten hoogste vijftien jaren of geldboete van de vijfde categorie opgelegd.

5. Indien een van de in het eerste lid omschreven feiten de dood ten gevolge heeft, wordt gevangenisstraf van ten hoogste achttien jaren of geldboete van de vijfde categorie opgelegd.

6. Artikel $25 \mathrm{I}$ is van overeenkomstige toepassing.'

\subsection{Nieuwe internationale ontwikkelingen}

In maart 2010 heeft de Europese Commissie een voorstel voor een richtlijn ter voorkoming en bestrijding van mensenhandel en de bescherming van slachtoffers ingediend. ${ }^{\mathrm{II}} \mathrm{Op}$ het moment van schrijven van dit preadvies zijn de onderhandelin-

III Voorstel voor een richtlijn van het Europees Parlement en de Raad ter voorkoming en bestrijding van mensenhandel en de bescherming van slachtoffers, en tot intrekking van Kaderbesluit 
gen over de ontwerprichtlijn in volle gang. De ontwerprichtlijn bouwt voort op het voorlopig resultaat van de onderhandelingen die in 2009 werden gevoerd over een voorstel voor een ontwerpkaderbesluit. Dit ontwerpkaderbesluit kon evenwel niet vóór de inwerkingtreding van het Verdrag van Lissabon op I december 2009 formeel worden vastgesteld. Om die reden heeft de Commissie een voorstel voor een richtlijn gepresenteerd. De besluitvormingsprocedure over de ontwerprichtlijn zal plaatsvinden volgens de medebeslissingsprocedure waarbij het Europees Parlement en de Raad gezamenlijk de bevoegdheid tot het vaststellen van wetgeving uitoefenen.

De ontwerprichtlijn beoogt het beschermingsniveau ten aanzien van de aanpak van mensenhandel binnen de Europese Unie te brengen naar het niveau van het Verdrag van de Raad van Europa inzake de bestrijding van mensenhandel van 2005. Laatstgenoemd instrument voorziet in belangrijke toegevoegde waarde ten opzichte van het Palermo Protocol en het EU-kaderbesluit uit 2002 door te voorzien in een alomvattende en multidisciplinaire benadering bij de aanpak van mensenhandel. Daarbij worden voorstellen gedaan terzake materieel strafrecht, preventie, vervolging, bescherming van en bijstand aan slachtoffers en monitoring. ${ }^{112}$ De ontwerprichtlijn neemt daarmee de kernresultaten van het Verdrag van de Raad van Europa over, maar voegt daaraan tevens enkele nieuwe elementen toe. In onderhavig verband verdient vermelding dat de omschrijving van uitbuiting ten opzichte van het Palermo Protocol en het Verdrag van de Raad van Europa wordt uitgebreid tot uitbuiting van gedwongen bedelarij en van criminele activiteiten. Ook wordt het voorstel gedaan tot verdere harmonisatie en aanscherping van straffen en tot ruimere extraterritoriale rechtsmacht.

\section{Het Straatsburgse perspectief}

\section{I Inleiding}

In een uiteenzetting over de strafbaarstelling van mensenhandel mag een bespreking van de relevante jurisprudentie van het Europees Hof voor de rechten van de mens (hierna: het Hof) niet ontbreken. In artikel 4 van het Europees Verdrag tot bescherming van de rechten van de mens en de fundamentele vrijheden (EVRM) is het verbod op slavernij en dwangarbeid neergelegd. Het luidt - voor zover hier van belang - in de Nederlandse vertaling als volgt:

'I. Niemand mag in slavernij of dienstbaarheid worden gehouden.

2. Niemand mag gedwongen worden dwangarbeid of verplichte arbeid te verrichten.'

2002/629/JBZ (COM (2010)95 final). Voor een eerste beoordeling van het voorstel door de Nederlandse regering zie het BNC-fiche (de afkorting BNC staat voor Beoordeling Nieuwe Commissievoorstellen), Kamerstukken II 2009/IO, 22 II 2, nr. IOI7.

II2 Zie uitgebreid de memorie van toelichting bij het voorstel van rijkswet tot goedkeuring van het verdrag, Kamerstukken II 2007/08, 3I 429 (R I855), nr. 3. Nederland heeft het verdrag op 22 april 2010 geratificeerd, waarna het op I augustus 2010 voor Nederland in werking is getreden. 
De in artikel 4 EVRM genoemde begrippen komen ook in min of meer dezelfde bewoordingen voor in de internationaal gehanteerde definitie van uitbuiting in de delictsomschrijving van mensenhandel, die - zoals we hebben gezien - model heeft gestaan voor de omschrijving van uitbuiting in artikel $273 \mathrm{flid} 2 \mathrm{Sr}$. De uitleg die het Hof geeft aan die begrippen is dan ook van belang voor de reikwijdte en strekking van de strafbaarstelling van mensenhandel in artikel $273 \mathrm{f} \mathrm{Sr}$. De duiding die in de internationale jurisprudentie aan deze begrippen wordt gegeven, heeft invloed op het nationale recht. ${ }^{\mathrm{II}}$

De jurisprudentie van het Hof ten aanzien van dit verdragsartikel is schaars. Het Hof heeft tot op heden slechts enkele keren de kans gekregen om zich over artikel 4 EVRM uit te spreken. Het Hof heeft die gelegenheden evenwel te baat genomen om een aantal belangrijke uitgangspunten te formuleren. De desbetreffende overwegingen van het Hof houden verband met de uitleg van de gehanteerde begrippen én de omvang van de uit artikel 4 EVRM voortvloeiende positieve verplichtingen om strafrechtelijke bescherming te bieden tegen vormen van moderne slavernij. ${ }^{\text {II4 }}$

\subsection{Siliadin tegen Frankrijk}

In 2005 constateert het Hof in de zaak Siliadin tegen Frankrijk voor het eerst een schending van artikel 4 EVRM. ${ }^{15}$ Deze zaak betreft een vijftienjarig meisje van Togolese nationaliteit, dat alleen en illegaal in Frankrijk verblijft en gedurende vier jaar, zeven dagen per week, I5 uur per dag onbetaald huishoudelijk werk moet verrichten bij een echtpaar dat haar onder erbarmelijke omstandigheden huisvest. Het Hof onderkent in zijn arrest het probleem van moderne slavernij en verplicht de verdragspartijen tot de inzet van het strafrecht ter bestrijding van de in artikel 4 EVRM omschreven verboden gedragingen.

In onderhavig verband is vooral ook van belang dat het Hof zich in dit arrest uitspreekt over wat er onder de begrippen slavernij, dienstbaarheid en gedwongen ('forced or compulsory') arbeid moet worden verstaan.

II3 Overigens is in dit verband niet alleen de rechtspraak van het Europees Hof voor de rechten van de mens van belang. Ook de jurisprudentie van andere internationale hoven en tribunalen die zich over de in de internationale definitie van uitbuiting omschreven vormen van uitbuiting uitspreken, is relevant. Dat geldt in het bijzonder voor de uitleg die het Hof van Justitie geeft aan het kaderbesluit en de toekomstige richtlijn.

II4 Zie over het leerstuk van de positieve verplichtingen onder het EVRM o.a. A. Mowbray, The development of positive obligations under the European Convention on Human Rights by the European Court of Human Rights, Hart Publishing, Oxford 2004; P.H.P.H.M.C. Van Kempen, Repressie door mensenrechten, over positieve verplichtingen tot aanwending van het strafrecht ter bescherming van fundamentele rechten (oratie RU Nijmegen), Wolf Legal Publishers, Nijmegen 2008; B.E.P. Myjer, Straatsburg zit er niet voor zweetvoeten (rede VU Amsterdam), Wolf Legal Publishers, Nijmegen 2004.

II5 Siliadin tegen Frankrijk, EHRM 26 juli 2005 (appl. no. 733I6/or); JV 2005, 425, m.nt. Lawson; EHRC 2005, I03, m.nt. Van der Velde. 
'II7. It remains to be ascertained whether there was "forced or compulsory" labour. This brings to mind the idea of physical or mental constraint. What there has to be is work "exacted ... under the menace of any penalty" and also performed against the will of the person concerned, that is work for which he "has not offered himself voluntarily" (...).

II8. The Court notes that, in the instant case, although the applicant was not threatened by a "penalty", the fact remains that she was in an equivalent situation in terms of the perceived seriousness of the threat. She was an adolescent girl in a foreign land, unlawfully present on French territory and in fear of arrest by the police. Indeed, $\mathrm{Mr}$ and Mrs B. nurtured that fear and led her to believe that her status would be regularised (...). Accordingly, the Court considers that the first criterion was met, especially since the applicant was a minor at the relevant time, a point which the Court emphasises.

IIg. As to whether she performed this work of her own free will, it is clear from the facts of the case that it cannot seriously be maintained that she did. On the contrary, it is evident that she was not given any choice.

I20. In these circumstances, the Court considers that the applicant was, at the least, subjected to forced labour within the meaning of Article 4 of the Convention at a time when she was a minor.'

Dan vervolgt het Hof met een beoordeling van de vraag of de omstandigheden van deze zaak ook aan de naar aard en ernst bemeten zwaardere maatstaf van slavernij of dienstbaarheid voldoen:

'I22. The Court notes at the outset that, according to the 1927 Slavery Convention, "slavery is the status or condition of a person over whom any or all of the powers attaching to the right of ownership are exercised". It notes that this definition corresponds to the "classic" meaning of slavery as it was practised for centuries. Although the applicant was, in the instant case, clearly deprived of her personal autonomy, the evidence does not suggest that she was held in slavery in the proper sense, in other words that $\mathrm{Mr}$ and Mrs B. exercised a genuine right of legal ownership over her, thus reducing her to the status of an "object".

I23. With regard to the concept of "servitude", what is prohibited is a "particularly serious form of denial of freedom" (...). It includes, "in addition to the obligation to perform certain services for others ... the obligation for the 'serf' to live on another person's property and the impossibility of altering his condition”. (...)

124. It follows in the light of the case-law on this issue that for Convention purposes "servitude" means an obligation to provide one's services that is imposed by the use of coercion, and is to be linked with the concept of "slavery" described above (...).

(...)

I26. In addition to the fact that the applicant was required to perform forced labour, the Court notes that this labour lasted almost fifteen hours a day, seven days per week. She had been brought to France by a relative of her father's, and had not chosen to work for $\mathrm{Mr}$ and Mrs B. As a minor, she had no resources and was vulnerable and isolated, 
and had no means of living elsewhere than in the home of Mr and Mrs B., where she shared the children's bedroom as no other accommodation had been offered. She was entirely at Mr and Mrs B.'s mercy, since her papers had been confiscated and she had been promised that her immigration status would be regularised, which had never occurred.

I27. In addition, the applicant, who was afraid of being arrested by the police, was not in any event permitted to leave the house, except to take the children to their classes and various activities. Thus, she had no freedom of movement and no free time.

I28. As she had not been sent to school, despite the promises made to her father, the applicant could not hope that her situation would improve and was completely dependent on Mr and Mrs B.

I29. In those circumstances, the Court concludes that the applicant, a minor at the relevant time, was held in servitude within the meaning of Article 4 of the Convention.'

\subsection{Rantsev tegen Cyprus en Rusland}

In de zaak Rantsev tegen Cyprus en Rusland heeft het Hof zich opnieuw over artikel 4 EVRM uitgesproken. ${ }^{\mathrm{Ir} 6}$ Deze zaak betreft een situatie van grensoverschrijdende mensenhandel, waarbij de twintigjarige Russische Rantseva vanuit Rusland op een artiestenvisum voor de 'variétébranche' naar Cyprus vertrekt en daar korte tijd later onder verdachte en onopgehelderd gebleven omstandigheden om het leven komt.

Het Hof bouwt in zijn arrest verder aan de positieve verplichtingen die ingevolge artikel 4 EVRM op de lidstaten rusten om mensenhandel te bestrijden. Bij het bepalen van de omvang daarvan baseert het Hof zich nadrukkelijk op de verplichtingen die in het Palermo Protocol en het Verdrag van de Raad van Europa ter bestrijding van mensenhandel zijn neergelegd. Het Hof verlangt een alomvattend en effectief beleid ter bestrijding van mensenhandel en verwacht veel meer dan strafbaarstelling alleen.

Ook in materiële zin zoekt het Hof aansluiting bij de genoemde internationale rechtsinstrumenten. Anders dan in het arrest in de zaak Siliadin, treedt het Hof in het onderhavige arrest niet in een beoordeling van de vraag van welke bestaande categorie verboden gedragingen als omschreven in artikel 4 EVRM onder de gegeven omstandigheden eventueel sprake is, maar kiest het ervoor mensenhandel ('trafficking') - dat niet in het EVRM genoemd wordt - als zodanig onder het bereik van artikel 4 EVRM te brengen. Het Hof overweegt daaromtrent het volgende:

'278. The Court notes that trafficking in human beings as a global phenomenon has increased significantly in recent years (...). In Europe, its growth has been facilitated in

II6 Rantsev tegen Cyprus en Rusland, EHRM 7 januari 2oro (appl. no. 25965/04); NTM/NJCMBulletin 20I0, p. 501 e.v. m.nt. Boot-Matthijssen; EHRC 20I0, 29, m.nt. Timmer. Zie ook A. Beyer, 'Rantsev v. Cyprus, een korte schets van de situatie in Nederland wat betreft mensenhandel', Ars Aequi, oktober 20I0, p. 684-69I. 
part by the collapse of former Communist blocks. The conclusion of the Palermo Protocol in 2000 and the Anti-Trafficking Convention in 2005 demonstrate the increasing recognition at international level of the prevalence of trafficking and the need for measures to combat it.

279. (...) In light of the proliferation of both trafficking itself and of measures taken to combat it, the Court considers it appropriate in the present case to examine the extent to which trafficking itself may be considered to run counter to the spirit and purpose of Article 4 of the Convention such as to fall within the scope of the guarantees offered by that Article without the need to assess which of three types of proscribed conduct are engaged by the particular treatment in the case in question.

(...)

28r. The Court considers that trafficking in human beings, by its very nature and aim of exploitation, is based on the exercise of powers attaching to the right of ownership. It treats human beings as commodities to be brought and sold and put to forced labour, often for little or no payment, usually in the sex industry but also elsewhere (...). It implies close surveillance of the activities of victims, whose movements are often circumscribed (...). It involves the use of violence and threats against victims, who live and work under poor conditions (...).

282. There can be no doubt that trafficking threatens the human dignity and fundamental freedoms of its victims and cannot be considered compatible with a democratic society and the values expounded in the Convention. In view of its obligation to interpret the Convention in light of present-day conditions, the Court considers it unnecessary to identify whether the treatment about which the applicant complains constitutes "slavery", "servitude" or "forced and compulsory labour". Instead, the Court concludes that trafficking itself, within the meaning of Article 3 (a) of the Palermo Protocol and Article 4(a) of the Anti-Trafficking Convention, falls within the scope of Article 4 of the Convention. (...).'

$\mathrm{Nu}$ het Hof mensenhandel als zodanig onder de reikwijdte van artikel 4 EVRM schaart, wordt nog eens bevestigd dat mensenhandel een schending van mensenrechten is. Vermelding verdient dat in artikel 5 (verbod van slavernij en dwangarbeid) van het Handvest van de grondrechten van de Europese Unie het verbod op mensenhandel expliciet is opgenomen.

Het Hof stelt bij de invulling van het begrip mensenhandel uitbuiting centraal. Het Hof definieert uitbuiting evenwel niet. Geweld en bedreiging worden door het Hof als kenmerken van mensenhandel genoemd. Opmerking verdient dat in de delictsomschrijving van mensenhandel in de door het Hof genoemde internationale instrumenten ook andere dwangmiddelen worden genoemd ('misbruik van een kwetsbare positie', 'bedrog' en 'misleiding'). Nu het Hof mensenhandel als zodanig onder het bereik van artikel 4 EVRM brengt, moeten ook die verschijningsvormen van mensenhandel als een schending van artikel 4 EVRM worden aangemerkt. ${ }^{117}$ In artikel $273 \mathrm{f} \mathrm{Sr}$ wordt naast de gedragingen die rechtstreeks voort-

II7 In die zin ook Boot-Mattthijsen in haar noot bij dit arrest, a.w., p. 513-5I4. 
vloeien uit de internationale instrumenten, ook een aantal andere gedragingen als mensenhandel gekwalificeerd. Wij stellen ons op het standpunt dat in elk geval wat betreft de Nederlandse rechtspraktijk ook die gedragingen als een schending van mensenrechten zouden moeten worden beschouwd.

\section{$4 \quad$ De huidige strafbaarstelling van mensenhandel}

\section{I Inleiding}

$\mathrm{Nu}$ we kennis hebben van de ontwikkeling van de strafbaarstelling van mensenhandel, is het tijd artikel $273 \mathrm{f} \mathrm{Sr}$ aan een nadere analyse te onderwerpen.

Het is al eerder gezegd: artikel $273 \mathrm{f} \mathrm{Sr}$ is een complexe en gelaagde bepaling. ${ }^{\mathrm{I} 8}$ Daarvoor zijn ten minste twee oorzaken aan te wijzen.

I. Mensenhandel is een ingewikkeld misdrijf en omvat vele strafbare feiten. ${ }^{\text {II9 }}$ Daarbij zijn doorgaans ten minste drie (groepen van) personen betrokken: de handelaar, de uitbuiter en het slachtoffer/de dienstverlener. Niet zelden is er sprake van een vierde groep: personen die uitbuiting faciliteren en daarvan rechtstreeks profijt trekken. Als de uitbuiter niet zelf de diensten afneemt, is er nog een vijfde groep van betrokkenen: de klant, de laatste in de keten. Bij uitbuiting in de seksbranche verleent het slachtoffer seksuele diensten aan de klant (prostituant of de toeschouwer van een seksshow). In de sectoren buiten de seksindustrie verricht het slachtoffer meestal diensten ten behoeve van de uitbuiter. In dat geval vallen uitbuiter en klant samen (tuinbouwer en zijn arbeider, of de bewoners van een huis en hun huishoudster/au pair). Mensenhandel betreft vaak transnationale criminaliteit. Dan zijn daarbij daders en/of slachtoffers van verschillende nationaliteiten en meerdere staten betrokken. Transnationale mensenhandel is doorgaans georganiseerde criminaliteit. Bij (grootschalige) mensenhandel wordt een keten van activiteiten doorlopen, van op uitbuiting gericht handelen tot aan de uitbuiting zelf, van het brengen van mensen (uit het ene land) in een uitbuitingssituatie (in een ander land) tot de uitbuiting en het houden van mensen in die situatie.

Bij de beoordeling van mensenhandel gaat het in elk concreet geval om de vraag of er sprake is van ongeoorloofde beïnvloeding/misbruik, óf van geoorloofd gebruik van de arbeid of diensten, van uitbuiting óf van uitbating. Onbehoorlijke en onfatsoenlijke uitbating getuigt van slecht werkgeverschap, maar hoeft nog geen uitbuiting op te leveren. Daartegen kan in het algemeen worden opgetreden op basis van arbeidswetgeving. De scheidslijn en het omslagpunt tussen strafwaardig en strafbaar gedrag enerzijds en onfatsoenlijk gedrag anderzijds, tussen onvrijwilligheid

II8 NRM 7, p. 506 en 575.

II9 Zie ook M. Smit en M. Boot, 'Het begrip mensenhandel in de Nederlandse context, Achtergronden en reikwijdte', Justitiële Verkenningen (JV7, 2007, 4, p. II). 
en vrijwilligheid bij degene die wordt uitgebaat, zijn niet steeds helder en scherp. Ook dat maakt mensenhandel conceptueel een lastig misdrijf.

2. Zoals beschreven in hoofdstuk 2 zijn mensenhandel en uitbating van prostitutie (bordeel- en souteneursverbod) steeds afzonderlijk strafbaar gesteld. Sinds de totstandkoming van de wetgeving inzake opheffing van het algemeen bordeelverbod heeft de wetgever ervoor gekozen om de verschijningsvormen van mensenhandel en uitbuiting te vatten in één bepaling: eerst op prostitutie gerichte mensenhandel tezamen met ongeoorloofde uitbating van prostitutie, daarna de uitbreiding daarvan tot alle vormen van seksuele dienstverlening, en ten slotte - als gevolg van implementatie van internationale regelgeving - de substantiële uitbreiding van mensenhandel tot overige vormen van dienstverlening en tot de verwijdering van organen. In één strafbepaling de strafbaarstelling van alle 'ketenpartners' in de mensenhandel, van handelaren tot uitbuiters, met inbegrip van rechtstreeks betrokken profiteurs, in alle takken van economische bedrijvigheid, in de seksindustrie én in de overige arbeidsmarkt en dienstverlening.

Bij de advisering over het voorstel van wet tot uitvoering van internationale regelgeving ter bestrijding van mensensmokkel en mensenhandel (zie hiervoor hoofdstuk 2.I.Io) is destijds gewezen op de grote voordelen van samenvoeging van alle vormen van mensenhandel in één strafbepaling. De prijs voor deze samenballing is een lang en niet steeds toegankelijk artikel. Het is niet aannemelijk dat het uit elkaar halen van alle strafwaardige verschijningsvormen van mensenhandel en de strafbaarstelling ervan in afzonderlijke bepalingen zouden leiden tot voor de uitvoeringspraktijk significant gemakkelijker toepasbare strafbepalingen.

De wetgever moet er steeds naar streven om zijn bedoelingen zo helder, eenvoudig en ondubbelzinnig mogelijk tot uitdrukking te brengen. Niet alle onderdelen van artikel $273 \mathrm{f} \mathrm{Sr}$ zijn (in hun onderlinge samenhang) volstrekt helder. De toelichting op de voorstellen tot uitvoering van internationale regelgeving ter bestrijding van mensensmokkel en mensenhandel is sober. Die beknoptheid komt deels voort uit een zekere terughoudendheid om begrippen, afkomstig uit internationale regelgeving, verder te duiden voor nationale consumptie, en om begrippen die nog niet zijn uitgekristalliseerd, in wetgeving en/of in de toelichtende stukken nader uit te werken. Voor zo'n uitwerking is de tijd soms nog niet rijp. ${ }^{120}$ De wetgever moet in dat geval ruimte laten voor grensverkenningen door de rechtspraktijk en/of wachten op nader onderzoek. ${ }^{\text {I2I }}$ Dat is vanuit het perspectief van de legaliteit en de rechtszekerheid zeker niet ideaal, maar soms onvermijdelijk. Deze rechtsonzekerheid heeft natuurlijk een prijs. De kale en sober toegelichte wetgeving heeft er zeker

I20 Opvallend genoeg vertoonde het parlement nauwelijks belangstelling voor de uitbreiding van het bereik van de strafbaarstelling van mensenhandel en had het geen behoefte aan verheldering van het daarmee samenhangende begrippenapparaat.

I2I Zie Kamerstukken II 2003/04, 29 29I, nr. 3, p. I8. De wetgever had nog onvoldoende beeld bij de verschijningsvormen van overige uitbuiting. 
mede toe bijgedragen dat de rechtspraktijk zoekende is geweest, in het bijzonder op het nieuwe terrein van de overige uitbuiting.

\subsection{Artikel $273 \mathrm{fSr}$}

\subsubsection{Algemeen}

Artikel $273 \mathrm{f}$ Sr gaat uit van een breed concept van mensenhandel. Het beoogt mensenhandel in al zijn vormen strafbaar te stellen. Mensenhandel in eigenlijke zin (het verhandelen van mensen met het oogmerk van uitbuiting), uitbuiting, profijt van uitbuiting en afgedwongen profijt van uitbating worden alle als mensenhandel gekwalificeerd. De bepaling voorziet in een ruimere strafrechtelijke bescherming van slachtoffers van mensenhandel dan de bescherming waarin internationale instrumenten voorzien waaraan Nederland is gebonden. We zullen in 4.2.2 tot en met 4.2.II de verschillende geledingen van deze lange bepaling langslopen.

Artikel $273 \mathrm{f} \mathrm{Sr}$ maakt geen onderscheid tussen daders die niet of wel voor de overheid werken. Ook de internationale instrumenten inzake mensenhandel maken dit onderscheid niet.

Artikel $273^{f}$ lid I Sr maakt in de onderdelen $I^{\circ}, 3^{\circ}, 4^{\circ}, 6^{\circ}, 7^{\circ}$ en $9^{\circ}$ geen onderscheid tussen slachtoffers. Deze onderdelen zien op volwassen en jeugdige slachtoffers. De onderdelen $2^{\circ}, 5^{\circ}$ en $8^{\circ}$ hebben specifiek betrekking op personen beneden I 8 jaar.

In artikel $273 \mathrm{f} \mathrm{Sr}$ wordt de ernst van de onderscheiden vormen van mensenhandel niet tot uitdrukking gebracht in specifieke strafmaxima. Voor seksueel gerelateerde mensenhandel en overige uitbuiting gelden dezelfde bovengrenzen. Deze maxima beogen voldoende ruimte te bieden voor een passende straftoemeting in elke zaak, voor de ernstigste zaken waarin schending van de lichamelijke en/of geestelijke integriteit aan de orde is, en voor de minder ernstige zaken. Het is verstandig van de wetgever geweest om geen gehoor te geven aan verlangens om wél te werken met specifieke strafmaxima. Het is immers een lastige en vermoedelijk moeizame exercitie om de ernst van verschillende vormen van uitbuiting in abstracto te waarderen en te voorzien van een passend maximum.

\subsubsection{Artikel 273 flid 1 , onderdeel $1^{\circ}$, juncto lid 2}

Artikel 273 flid I, onderdeel I, en lid 2 geven uitvoering aan de in hoofdstuk 2.I.9 vermelde internationale regelgeving. Dit onderdeel tezamen met de omschrijving van uitbuiting in het tweede lid loopt vrijwel één op één met de definities van mensenhandel in deze internationale instrumenten.

Onderdeel $I^{\circ}$ ziet op mensenhandel in enge vorm, op de handelingen die erop gericht zijn om personen uit te buiten en die dus voorafgaan aan de daadwerkelijke uitbuiting. 
a. Handelingen: een ander werven, vervoeren, overbrengen, huisvesten of opnemen ${ }^{122}$ Dit element beoogt alle opeenvolgende handelingen te omvatten die (kunnen) leiden tot de beoogde uitbuiting. Deze handelingen moeten ruim worden opgevat in de betekenis die zij hebben in het gewone spraakgebruik. ${ }^{\mathrm{I23}}$

b. Ongeoorloofde middelen ten opzichte van een ander: dwang, geweld of een andere feitelijkheid, dreiging met geweld of een andere feitelijkheid, afpersing, fraude, misleiding, misbruik van uit feitelijke omstandigheden ${ }^{124}$ voortvloeiend overwicht ${ }^{125}$, misbruik van een kwetsbare positi ${ }^{126}$ of het geven of ontvangen van betalingen of voordelen om de instemming van een persoon te verkrijgen die zeggenschap heeft over die ander ${ }^{127}$

Het gebruik van deze ongeoorloofde middelen door de dader genereert onvrijwilligheid in enigerlei vorm bij het slachtoffer. Tot onvrijwilligheid behoort ook het ontbreken of de vermindering van de mogelijkheid voor het slachtoffer om een bewuste keuze te maken. ${ }^{128}$ Het slachtoffer is niet of in verminderde mate in staat zich te onttrekken aan de ongeoorloofde beïnvloeding of de uitbuitingssituatie of kan redelijkerwijs menen geen vrije keuze te kunnen maken.

I22 In het kaderbesluit en in de ontwerprichtlijn van 2010 wordt na 'opnemen' nog toegevoegd: 'met inbegrip van het wisselen of het overdragen van de zeggenschap over een persoon'. De wetgever heeft zich kennelijk op het standpunt gesteld dat deze handelingen reeds zijn opgenomen in de daarvoor genoemde handelingen.

I23 Zie N-L-R, 'Het Wetboek van Strafrecht', aantek. 3.2 bij artikel $273 \mathrm{f}$ Sr en de conclusie van AG Knigge bij HR 27 oktober 2009, LJN: BI7099, par. I9.

I24 Bij de incorporering van artikel 250a (oud) Sr in artikel 273a (oud) Sr is 'omstandigheden' geruisloos in de plaats gekomen van 'verhoudingen'. Dit houdt een bescheiden verruiming in.

I25 Zie ook noot 44. Het middel 'misbruik van uit feitelijke omstandigheden voortvloeiend overwicht' is een nationale verworvenheid en was als gezegd al opgenomen in artikel $250 a$ (oud) Sr. Het middel wordt ook genoemd in artikel 248a Sr (verleiding van een persoon onder 18 jaar tot ontucht). Het wordt niet genoemd in de internationale instrumenten, waar gesproken wordt van 'abuse of power'. Misbruik van overwicht is ruimer en omvat mede misbruik van gezag. Het in de internationale instrumenten gebruikte middel 'misbruik van een kwetsbare positie' is ook gericht op een ruime bescherming.

I26 In artikel 2 lid 2 van de ontwerp richtlijn wordt uitgelegd wanneer een kwetsbare positie zich voordoet: de persoon heeft geen reëel of aanvaardbaar alternatief dan zich te onderwerpen aan het misbruik. In het explanatory report (par. 83) bij het Verdrag van de Raad van Europa wordt ten aanzien van het middel 'misbruik van een kwetsbare positie' opgemerkt dat dit omvat 'any state of hardship in which a human being is impelled to accept being exploited', daaronder begrepen 'abusing the economic insecurity or poverty of an adult hoping to better their own and their family's lot.'

I27 Het laatste middel kan worden aangemerkt als misbruik van een kwetsbare positie van het slachtoffer die onder zeggenschap van een ander staat.

I28 Vgl. de memorie van toelichting bij voorstel van wet tot wijziging van de artikelen 250 obis en 25 oter van het Wetboek van Strafrecht, Kamerstukken II I988/89, 2I 207, nr. 3, p. 3 en 4: 'De in dit verband verboden gedragingen, bestaande in het aanwenden van dwang door geweld of een andere feitelijkheid, het misbruik maken van uit feitelijke verhoudingen voortvloeiend overwicht of misleiding, beïnvloeden de wil waaronder begrepen de keuzemogelijkheid van het slachtoffer, in die zin dat zij leiden tot het ontbreken van vrijwilligheid waartoe ook behoort het ontbreken of de vermindering van de mogelijkheid een bewuste keuze te maken. De omstandigheid dat het slachtoffer reeds eerder bij prostitutie betrokken was, vormt op zich geen aanwijzing inzake vrijwilligheid.' 
Het opzetvereiste zit begrepen in de ongeoorloofde gedraging (handelingen met gebruik van ongeoorloofd middel). Men spreekt in dit verband wel van 'ingeblikt opzet'.

Onvrijwilligheid heeft twee kanten: een ongeoorloofde activiteit van de dader (ongeoorloofde beïnvloeding) enerzijds én een ontvankelijkheid en conditionering van het slachtoffer voor die ongeoorloofde beïnvloeding anderzijds. De interactie tussen het handelen van de dader en de situatie waarin het slachtoffer verkeert, ligt bij deze ongeoorloofde middelen verschillend. Daarom zijn deze bestanddelen een 'mixed bag'.

De middelen dwang, geweld of een andere feitelijkheid, bedreiging daarmee, afpersing of fraude staan min of meer los van de persoonlijke omstandigheden van het slachtoffer, de aard van de te verrichten of verrichte arbeid of diensten of de omstandigheden waaronder die worden verricht. Dat is anders bij misleiding, het maken van misbruik van uit feitelijke omstandigheden voortvloeiend overwicht, misbruik van een kwetsbare positie of het geven of ontvangen van betalingen of voordelen om de instemming van een persoon te verkrijgen die zeggenschap heeft over die ander. ${ }^{129}$ Daar is het misbruik, de ongeoorloofde beïnvloeding, rechtstreeks gerelateerd aan of volgt rechtstreeks uit de uitbuitingssituatie, dus de kwetsbare positie van het slachtoffer ${ }^{130}$, en de aard van het werk. Een voorbeeld van uitbuiting in de prostitutie, reeds genoemd in hoofdstuk 2, kan dat verduidelijken. Dit voorbeeld is ook relevant voor overige uitbuiting. Blijkens de wetsgeschiedenis kan 'misbruik van uit feitelijke omstandigheden ${ }^{131}$ voortvloeiend overwicht' worden verondersteld indien een prostituee in een situatie verkeert of komt te verkeren die niet gelijk is aan de omstandigheden waarin een mondige prostituee ${ }^{\mathrm{I32}}$ in Nederland pleegt te verkeren. Deze vergelijking heeft naar ons oordeel relevantie voor de beoordeling van de (vrije) keuze om in de prostitutie te gaan of daarin te blijven. De omstandigheid dat een persoon in de prostitutie gaat, kan immers een gevolg zijn van de uitbuitingssituatie waarin deze persoon zich bevindt. De Nationaal Rapporteur Mensenhandel stelt zich daarentegen op het standpunt dat de vergelijking met de mondige prostituee in Nederland geen rol kan spelen bij de beoordeling van de 'vrije' keuze om in de prostitutie te gaan. ${ }^{\mathrm{I3}}$

Die ongelijke situatie is bijvoorbeeld illegaliteit, verslaving, zeer jeugdige leeftijd, het niet beschikken over eigen financiële middelen of een reisdocument. Het misbruik volgt rechtstreeks en zonder meer uit die situatie en uit de (beoogde) uit-

I29 Het onderscheid tussen de aard van de middelen werd tekstueel gemarkeerd in artikel 250a lid I, onderdeel I (oud) Sr. Daarin was 'dwingen' gekoppeld aan de middelen 'geweld of een andere feitelijkheid' en 'bedreiging met geweld of een andere feitelijkheid' en 'bewegen' gekoppeld aan de middelen 'misbruik van uit feitelijke verhoudingen voortvloeiend overwicht' en 'misleiding'.

I30 Kwetsbaarheid kan van lichamelijke, psychische, emotionele, familie gerelateerde, sociale of economische aard zijn. Een kwetsbare positie kan een gevolg zijn van illegale binnenkomst of verblijf, ongedocumenteerde status, zwangerschap, psychische of lichamelijke handicap, verslaving, een verminderd beoordelingsvermogen door onvolwassenheid of een stoornis.

I3I Onder die wetsgeschiedenis als gezegd nog 'verhoudingen' in plaats van 'omstandigheden'.

I32 De mondige prostituee in Nederland als trots ijkpunt in het schemergebied tussen uitbuiting en uitbating.

I33 NRM 7, p. 449 en 506. 
bating in de prostitutie. Het bestanddeel 'misbruik' wordt aldus geobjectiveerd. Zulks objectiveert ook de subjectieve beleving van het slachtoffer in zo'n ongelijke situatie. Het kan terecht menen dat het in de prostitutie moest gaan werken of moest blijven werken.

Misbruik van overwicht en misbruik van een kwetsbare positie zijn bij uitstek het gereedschap van de moderne mensenhandelaar. Beide bestanddelen voorzien in een ruime bescherming van slachtoffers. Zij dekken en overlappen elkaar grotendeels. Misbruik van overwicht verwijst primair naar de dader, naar zijn overwicht over het slachtoffer. Misbruik van een kwetsbare positie verwijst primair naar de situatie waarin het slachtoffer zich bevindt. ${ }^{\mathrm{I} 4}$ Overwicht veronderstelt (relatieve) zwakte en kwetsbaarheid. Kwetsbaarheid is een bron voor overwicht. Overwicht en kwetsbaarheid kunnen misbruik conditioneren. In de rechtspraktijk worden deze bestanddelen dan ook vaak in één adem genoemd.

De bestanddelen inzake ongeoorloofde middelen tot beïnvloeding in onderdeel $\mathrm{I}^{\circ}$

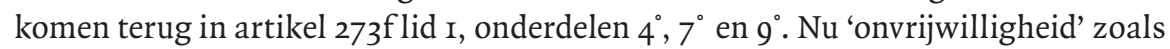
wij hierna in hoofdstuk 4.2.3 zullen zien een element van uitbuiting is, kunnen deze middelen ook behulpzaam zijn bij de beoordeling van dit element in een van de in artikel 273 flid 2 genoemde vormen van uitbuiting.

\section{c. Oogmerk van uitbuiting of van de verwijdering van organen}

Het handelen van de dader geschiedt met het oogmerk van uitbuiting en de verwijdering van organen. Uitbuiting wordt omschreven in het tweede lid (zie hierna). Voor de vervulling van de delictsomschrijving is niet relevant dat de uitbuiting daadwerkelijk heeft plaatsgevonden dan wel de organen zijn verwijderd. Hier is niets nieuws onder de zon. ${ }^{135}$ De dader moet het oogmerk hebben. Niet is vereist dat de dader de bedoeling heeft bij de beoogde uitbuiting betrokken te zijn, ook niet dat zijn handelen exclusief op uitbuiting is gericht. Het slachtoffer behoeft niet van de bedoelingen van de dader op de hoogte te zijn.

De Hoge Raad heeft - overigens zonder nadere uitleg - overwogen dat ten aanzien van uitbuiting een zwaarder opzetvereiste geldt, namelijk in de vorm van het oogmerk van uitbuiting. ${ }^{136}$ In het licht van deze overweging rijst de vraag wat de betekenis van oogmerk moet zijn in de context van de strafbaarstelling van mensenhandel.

Het begrip oogmerk in artikel $273^{\mathrm{f}}$ lid I, onderdeel $\mathrm{I}^{\circ}$, Sr vormt de vertaling van het in het Palermo Protocol en het EU-kaderbesluit opgenomen Engelse begrip 'for the purpose of'. Het Engelse begrip 'for the purpose of' duidt op een bepaald doel of

I34 Vgl. NRM 7, p. 534. Zie ook Hoge Raad 8 september 20I0, LJN: BJ3537, m.nt. Vellinga.

I35 Zie de beschrijving van de parlementaire geschiedenis van een eeuw geleden inzake het voorstel van wet bestrijding van zedeloosheid in hoofdstuk 2.I.2 en noot I9.

I36 HR 27 oktober 2009, LJN: BI7099 (r.o. 2.5.I). 
een bepaald gevolg dat de dader met diens handelen ('vervoer' enz.) voor ogen staat: uitbuiting.

Oogmerk wordt als een specifieke, meer beperkte vorm van opzet beschouwd. Volgens de wetgever van I886 wordt met oogmerk 'iets meer bepaalds' dan met opzet geëist. Voorwaardelijk opzet is niet voldoende. Uit de rechtspraak en de rechtsgeleerde literatuur kan worden afgeleid dat bij oogmerk een soort noodzakelijkheidsbewustzijn wordt vereist. ${ }^{137}$ Tegelijkertijd is voor de precieze invulling van het begrip oogmerk ook het delict in kwestie van betekenis. ${ }^{1{ }^{8}}$ Hazewinkel-Suringa wijst er dan ook terecht op dat de moeilijkheid bij oogmerk is dat de term soms eng, soms ruim moet worden opgevat. ${ }^{139}$ Wanneer het begrip oogmerk ruim wordt opgevat, wordt relevant geacht welke strafbaarheid de wetgever heeft beoogd. Dat is naar onze mening ook hier van belang. Aard en strekking van de strafbaarstelling van mensenhandel moeten worden betrokken bij de vaststelling van de eisen die aan het bewijs voor het oogmerk worden gesteld.

Opvallend is dat de wetsgeschiedenis zwijgt over de nadere inhoud van het begrip oogmerk in de context van mensenhandel. De wetsgeschiedenis bevat derhalve geen aanknopingspunten voor een uitleg waarin van de dader van mensenhandel een noodzakelijkheidsbewustzijn wordt geëist. De wetgever beoogt een ruime en doeltreffende strafrechtelijke bescherming tegen mensenhandel te bieden. Wanneer de doelstelling van de wetgever met betrekking tot de strafbaarheid mag worden meegewogen, zou naar onze mening voldoende moeten zijn dat de dader weet of het althans mogelijk acht dat zijn handelen verband houdt met uitbuiting. Wij kiezen dus voor een ruime opvatting van het begrip oogmerk.

Artikel $273 \mathrm{flid} \mathrm{I}$, onderdeel $\mathrm{I}^{\circ}$, Sr is als gezegd een gecompliceerde bepaling. Ongeoorloofde beïnvloeding is expliciet gekoppeld aan een aantal neutrale activiteiten (vervoeren enz.), maar is ook verweven met het doel van de handelingen, de uitbuiting. Anders gezegd: onvrijwilligheid verschijnt twee maal, (I) als gevolg van de ongeoorloofde beïnvloeding en (2) als element van de beoogde uitbuiting.

Artikel 3, onderdeel (b), Palermo Protocol, artikel 2 lid 2 EU-kaderbesluit, artikel 4, onderdeel b, Verdrag van de Raad van Europa en artikel 2 lid 4 ontwerp richtlijn bepalen uitdrukkelijk dat instemming van het slachtoffer met de beoogde uitbuiting

I37 J. De Hullu, Materieel strafrecht (3e druk), Kluwer, Deventer 2006, p. 235-238. Vgl. HR 2I april I998, NJ I998, 6ro, waarin de Hoge Raad overweegt dat oogmerk van de verdachte aanwezig is wanneer 'zijn handelen, naar hij moet hebben beseft, als noodzakelijk en dus door hem gewild gevolg meebracht (...).'

I38 De Hullu, a.w., p. 237, waar wordt verwezen naar HR 27 mei I929, NJ I929, p. I269, waarin de Hoge Raad overweegt dat in algemene zin 'de term oogmerk in het Wetboek van Strafrecht niet overal in de door requirant daaraan mede ten deze gehechte enge betekeenis van naaste doel of oogmerk wordt gebruikt, doch hier en daar ook wel eens in de ruimere beteekenis van opzet, zoo b.v. in de artt. 92-94 van dat Wetboek (...).'

I39 D. Hazewinkel-Suringa, 'Inleiding tot de studie van het Nederlandse Strafrecht', bewerkt door mr. J. Remmelink, Gouda Quint, Deventer, vijftiende druk (I996), p. 2 I6. 
niet relevant is, wanneer een van de ongeoorloofde middelen is gebruikt. Het kaderbesluit en de ontwerp richtlijn gaan nog verder en bepalen dat ook instemming met feitelijke uitbuiting niet relevant is.

Instemming met uitbuiting is innerlijk tegenstrijdig, omdat uitbuiting een element van onvrijwilligheid bevat. De wetgever vond de irrelevantie van instemming met de uitbuiting kennelijk zo evident dat hij het niet nodig achtte deze in onze eigen wetgeving te expliciteren en er veel woorden aan vuil te maken. ${ }^{\text {.40 }}$ Soms kan het geen kwaad om evidenties tot uitdrukking te brengen. Bovendien is er - zeker gelet op de ontwikkeling in de rechtspraak - aanleiding om deze evidentie enigszins te relativeren. De dader handelt in strijd met artikel 273 flid I, onderdeel $I^{\circ}$, Sr, als het gebruik van een van de in dit onderdeel genoemde ongeoorloofde middelen en de (beoogde) uitbuiting kunnen worden bewezen, ook al zou het slachtoffer hebben ingestemd met de (beoogde) uitbuiting. Maar daarmee is nog niet gezegd dat eventuele instemming van de betrokken persoon met de (beoogde) werkzaamheden niet relevant kan zijn voor beantwoording van de vraag of er sprake is (van oogmerk) van uitbuiting. Ook in uitbuiting zit immers een element van onvrijwilligheid. Instemming met uitbating levert in de regel geen uitbuiting op. Het zou daarom verstandig zijn dat bij een goede gelegenheid van overheidswege tot uitdrukking wordt gebracht wat de betekenis en de consequenties van deze bepaling zijn. ${ }^{\mathrm{I} I \mathrm{I}}$

\subsubsection{Artikel 273 flid 2 (definitie van uitbuiting)}

Uitbuiting wordt in navolging van de reeds genoemde internationale instrumenten omschreven in het tweede lid. In die instrumenten wordt uitbuiting als zodanig niet strafbaar gesteld. Uitbuiting is in die instrumenten doel van mensenhandel. Daarop is mensenhandel gericht.

De omschrijving van uitbuiting in het tweede lid is relevant voor de onderdelen $\mathrm{I}^{\circ}$ en $2^{\circ}$, en voor onderdeel $6^{\circ}$, waarin het opzettelijk voordeel trekken uit uitbuiting strafbaar is gesteld.

In artikel $273 \mathrm{f} \mathrm{Sr}$ is uitbuiting niet als uitbuiting strafbaar gesteld. Maar in artikel 273 flid I, onderdeel $4^{\circ}$, worden handelingen strafbaar gesteld die als uitbuiting kunnen worden aangemerkt.

I40 Kamerstukken II 2003/04, 29 29I, nr. 3, p. I9. Daar wordt gesproken van een bepaling 'ten overvloede'.

I4I Vgl. UNODC Model Law against Trafficking in Persons (UNODC Model Law), p. 34: 'This provision restates existing international legal norms. It is logically and legally impossible to "consent" when one of the means listed in the definition is used. Genuine consent is only possible and legally recognized when all the relevant facts are known and a person exercises free will. However, if there is any doubt about the issue of consent in domestic law, a separate paragraph should be included in the law.' Zie verder conclusie van AG Knigge bij HR 27 oktober 2009, LJN: BI7099 (hoofdstuk 4.3.2). 
De internationale instrumenten inzake mensenhandel gaan uit van een breed concept van uitbuiting zodat nieuwe vormen van uitbuiting in arbeid en dienstverlening niet buiten bereik blijven. Uitbuiting wordt in die instrumenten en in het tweede lid niet in kwalitatieve zin gedefinieerd. Uitbuiting wordt in het algemeen geassocieerd met bijzonder harde en grove arbeidsomstandigheden in strijd met de menselijke waardigheid. ${ }^{142}$ Wat het gewicht van het ingrediënt 'strijd met de menselijke waardigheid' betreft wordt verwezen naar de hoofdstukken 3.3 en 4.3.I in fine. Onfatsoenlijk werkgeverschap dat leidt tot een maatschappelijk ongewenste arbeidssituatie, levert in het algemeen geen uitbuiting op.

Uitbuiting wordt in het tweede lid nader uitgewerkt in een aantal vormen van uitbuiting. Deze vormen zijn ook niet nader gedefinieerd. Ingevolge het tweede lid omvat uitbuiting 'ten minste ${ }^{\mathrm{I} 43}$ uitbuiting in de prostitutie, andere vormen van seksuele uitbuiting, gedwongen of verplichte arbeid of diensten, slavernij en met slavernij of dienstbaarheid te vergelijken praktijken.'

De in de internationale instrumenten en in lid 2 genoemde vormen van uitbuiting hebben betrekking op alle slachtoffers, jong en oud. In uitbuiting zit een element van onvrijwilligheid. De vraag in hoeverre het element van onvrijwilligheid relevant is voor de beoordeling van uitbuiting van kinderen is niet in het algemeen te beantwoorden. Dat is onder meer afhankelijk van de situatie waarin het kind verkeert, de leeftijd van het kind, de aard van de arbeid of dienstverlening, en de arbeidsomstandigheden. De ernstigste vormen van kinderarbeid leveren steeds uitbuiting op (zie hierna ook hoofdstuk 4.2.5). ${ }^{\text {I44 }}$

In een internationaal instrument inzake mensenhandel kan men niet heen om een expliciete vermelding van uitbuiting in de prostitutie. ${ }^{145}$ Deze vorm van uitbuiting

I42 Zie UNDOC Model Law, p. 36. 'Grove' is de vertaling van 'abusive'. In de Engelse term komt het element van misbruik beter tot uitdrukking.

I43 Deze woorden zijn niet ongebruikelijk in internationale instrumenten. Daarmee wordt aan partijen een minimumverplichting opgelegd. Partijen kunnen ook andere niet genoemde vormen van uitbuiting opnemen in hun nationale wetgeving. In feite heeft de wetgever dat gedaan door onder uitbuiting ook te verstaan 'met dienstbaarheid te vergelijken praktijken'. Maar het gebruik van 'ten minste' in nationale wetgeving is ongebruikelijk. Het lijkt erop dat de wetgever ruimte heeft willen bieden voor andere strafrechtelijk relevante vormen van uitbuiting. Maar in welke zin blijft onduidelijk. Het gebruik van 'ten minste' in het tweede lid heeft naar ons oordeel geen praktische gevolgen. Het is immers niet aannemelijk dat een vervolging wordt ingesteld voor

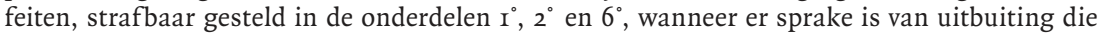
niet reeds valt onder het bereik van uitbuiting, zoals breed omschreven in tweede lid. AG Knigge heeft dus een punt wanneer hij zich in zijn conclusie bij HR van 27 oktober 2009, LJN: BI7099, verbaast over het gebruik van 'ten minste'. Hij ontleent aan deze woorden overigens een extra argument voor een ruimhartige strafrechtelijke bescherming van het slachtoffer van mensenhandel.

I44 Zie ILO-Verdrag betreffende het verbod op en de onmiddellijke uitbanning van de ergste vormen van kinderarbeid (ILO I82, Genève, I999).

I45 In veel landen is uitbuiting in de prostitutie synoniem met uitbating in de prostitutie. Bij de onderhandelingen over het Palermo Protocol is met een grote boog heen gelopen om het verschijnsel prostitutie en de al dan niet strafwaardigheid van de uitbating ervan. Het Palermo Protocol geeft daarom geen nadere definitie van 'uitbuiting van prostitutie van anderen' en 
opent de reeks in het tweede lid. Daarbij is de menselijke waardigheid onmiskenbaar rechtstreeks in het geding. ${ }^{146}$ Uitbuiting in prostitutie is reeds lang strafbaar gesteld. Vervolgens worden 'andere vormen van seksuele uitbuiting' genoemd, zoals uitbuiting in pornografie en pornografische vertoningen. In de definitie wordt onderscheid gemaakt tussen seksuele uitbuiting en gedwongen arbeid en diensten. ${ }^{\text {I }}{ }^{7}$ In de kern is seksuele uitbuiting een species van het genus gedwongen of verplichte arbeid of dienstverlening, iemand ertoe dwingen zich beschikbaar te stellen tot het verrichten van seksuele handelingen met of voor een derde tegen betaling.

De overige vormen van uitbuiting zijn algemeen geformuleerd en verwijzen niet naar een specifieke tak van dienstverlening.

Voor een nadere duiding van de in lid 2 genoemde vormen van uitbuiting zijn de internationale instrumenten waaraan deze begrippen zijn ontleend, en de door de internationale rechtspraktijk aan die begrippen gegeven uitleg relevant.

'Gedwongen arbeid en diensten' zijn standaardbegrippen. ${ }^{148}$ 'Arbeid' en 'diensten' veronderstellen een relatie tussen werknemer en werkverschaffer. De arbeid of de dienst wordt verricht onder leiding of ten behoeve van deze werkverschaffer of een derde. De woorden 'gedwongen' of 'verplichte' zijn min of meer synoniem. ${ }^{\text {I49 }}$ Daarin zit onvrijwilligheid: het ontbreken van een vrije wil om het werk aan te vatten of ermee te stoppen. Bij de uitleg van deze begrippen kan aansluiting worden gezocht bij de ILO-verdragen. Daarin wordt onder gedwongen arbeid verstaan elke arbeid of dienst waarvoor een persoon zich niet vrijwillig beschikbaar heeft gesteld of

'andere vormen van seksuele uitbuiting. Het mikt op een zeer brede ratificatie en treedt niet in de nationale politiek van staten inzake prostitutie. De internationale instrumenten spreken van 'exploitation of the prostitution of others'. Dit is door Nederland geïmplementeerd als 'uitbuiting van een ander in de prostitutie'. Daarmee wordt hetzelfde bedoeld. Volledigheidshalve zij vermeld dat er ten aanzien van de betekenis in de Nederlandse taal van het begrip 'exploitation' bij een eerdere gelegenheid discussie is geweest, te weten in het kader van het Verdrag inzake de uitbanning van alle vormen van discriminatie van vrouwen. Bij die gelegenheid is het standpunt ingenomen dat het begrip een andere betekenis heeft dan het Nederlandse woord 'exploitatie'. Het begrip ‘exploitation' ziet op uitbuiting en niet op uitbating (Handelingen II, 2 april I987, 66-3493).

I46 Zie ook NRM 7, p. 450.

I47 Zie ook UNODC Model Law, p. I5.

I48 Zie voor de betekenis, een analyse en een nadere (positieve en negatieve) definitie van deze vorm van uitbuiting Jill E.B. Coster van Voorhout 'Human trafficking for labour exploitation: Interpreting the crime', Utrecht Law Review Vol. 3, Issue 2 (december) 2007.

I49 Het woord 'verplicht' is de Nederlandse vertaling van 'compulsary' en is afkomstig uit het kaderbesluit en artikel 4 lid 2 EVRM. Het betekent ook (af)gedwongen of opgelegd en zit in die betekenis zeer dicht tegen 'forced' aan. Het Palermo Protocol, het Verdrag van de Raad van Europa en de ontwerp richtlijn volstaan met 'forced labour or services'. 
Slavernij en daarmee te vergelijken praktijken zijn ook begrippen die afkomstig zijn uit internationale regelgeving. Slavernij is de situatie waarbij de uitbuiter 'eigendomsrecht' over een ander uitoefent, dat wil zeggen macht uitoefent die verbonden is met het recht van eigendom. ${ }^{152}$ De uitbuiter behandelt de ander als zijn bezit. Met slavernij te vergelijken praktijken zijn vormen van ontoelaatbare (schuld)binding, zoals lijfeigenschap, gedwongen huwelijk en uitbuiting van kinderen.

Dienstbaarheid is onderworpenheid, een toestand van dominantie over het slachtoffer op werk- en leefgebied en van een (dubbele of meervoudige) ${ }^{153}$ afhankelijkheid van het slachtoffer, waarin het wordt gedrongen om arbeid of diensten te verrichten en het (redelijkerwijs) gelooft dat het geen uitvoerbaar alternatief heeft voor het verrichten daarvan. ${ }^{54}$ Dienstbaarheid vormt een ernstige inbreuk op de persoonlijke vrijheid en is te beschouwen als een lichtere vorm van slavernij.

Bij slavernij, met slavernij te vergelijken praktijken, dienstbaarheid, en gedwongen arbeid of diensten is sprake van een glijdende schaal van absolute onvrijwilligheid naar relatieve onvrijwilligheid. De ruimte voor het slachtoffer om te kiezen voor

I50 In de richtlijnen van de ILO worden zes elementen gedetecteerd die een indicatie kunnen vormen voor gedwongen arbeid of dienstverlening: (I) fysiek of seksueel geweld, (2) beperking van de bewegingsvrijheid, bijvoorbeeld tot de werkplek of een beperkt gebied, (3) arbeidsbinding door schuld, (4) inhouding van loon of het weigeren van betaling ervan, (5) innemen van identiteitsdocumenten, waardoor de arbeider niet weg kan of zijn identiteit of status niet kan bewijzen en (6) dreiging van aangifte bij de autoriteiten. Daaraan kunnen misleiding en het doen van valse beloften worden toegevoegd. Bedreiging met straf omvat vele vormen van straf: fysiek geweld tegen het slachtoffer of zijn familie, vrijheidsbeneming, verlies van rechten of privileges, aangifte bij de autoriteiten, in geval van prostitutie melding daarvan aan familie, inhouding van loon bijvoorbeeld als de arbeider weigert niet overeengekomen overwerk te verrichten. Zie ook hoofdstuk 3.2 .

I5I Vgl. artikel 4 lid 3 EVRM: niet als dwangarbeid worden beschouwd: gewoon werk van een gedetineerde, elke dienst van militaire aard of in het kader van vervangende dienstplicht, dienst die bij een noodtoestand of ramp wordt gevorderd, of werk of dienst die hoort bij normale burgerplichten.

I52 Zie ook artikel 7 lid I, onderdelen c en g, en lid 2, onderdeel c, Statuut van Rome. Onderdeel c van lid 2 luidt: 'Enslavement means the exercise of any or all of the powers attaching to the right of ownership over a person and includes the exercise of such power in the course of trafficking in persons, in particular women and children.'

I53 Een afhankelijkheid van de uitbater voor werk, huisvesting en/of reisdocumenten.

I54 In eerdere versies van de definitie van mensenhandel in het Palermo Protocol werd 'dienstbaarheid' omschreven als 'the status or condition of dependency of a person who is unlawfully compelled or coerced by another to render any service to the same person or to others and who has no reasonable alternative but to perform the service; it includes domestic service and debt bondage'. Zie ook artikel 4 EVRM en EHRM 26 juli 2005, Siliadin tegen Frankrijk (zie hoofdstuk 3.2). Wat betreft dienstbaarheid heeft de wetgever artikel I lid I (d) van het EU-kaderbesluit letterlijk overgenomen ('slavernij of met slavernij of dienstbaarheid te vergelijken praktijken'). Dienstbaarheid is ten onrechte niet als een zelfstandige vorm van uitbuiting genoemd, maar alleen als een praktijk die met dienstbaarheid te vergelijken is. 
een reëel alternatief is afwezig (bij slavernij) dan wel - in verschillende gradaties ingeperkt. Gedwongen arbeid of diensten vormen de ondergrens. ${ }^{155}$

Het Palermo Protocol, het Verdrag van de Raad van Europa en de ontwerprichtlijn merken verwijdering van organen aan als een vorm van uitbuiting. ${ }^{156}$ In orgaanverwijdering ontbreekt - anders dan in de andere vormen van uitbuiting - op zichzelf beschouwd, een element van onvrijwilligheid. Dit verschil is verklaarbaar in het licht van de onvrijwilligheid die voortvloeit uit het op uitbuiting gerichte ongeoorloofde gerichte handelen in die instrumenten. Orgaanverwijdering staat in de context van uitbuiting.

De wetgever heeft er destijds voor gekozen om orgaanverwijdering conceptueel niet op één lijn te stellen met de overige vormen van uitbuiting en deze niet op te nemen in het tweede lid, maar afzonderlijk te vermelden in de onderdelen $1^{\circ}, 2^{\circ}, 4^{\circ}$, $5^{\circ}, 7^{\circ}, 8^{\circ}$ en $9^{\circ}$ van artikel $273^{\mathrm{flid}} \mathrm{I} .{ }^{\mathrm{I5}}{ }^{\mathrm{D}}$ Daarmee is volledig voldaan aan onze internationale verplichtingen.

In de definitie van uitbuiting in de internationale instrumenten inzake mensenhandel en in het tweede lid van artikel $273 \mathrm{f} \mathrm{Sr}$ wordt niet gerefereerd aan het element van winstoogmerk. ${ }^{158}$ Het behalen van (onevenredig) profijt is natuurlijk wel eerste motief voor uitbuiting. Profijt wordt mogelijk gemaakt of bevorderd door slechte arbeidsomstandigheden zoals onderbetaling en lange werktijden, of slechte huisvesting. Die omstandigheden kunnen wijzen op een uitbuitingssituatie. Profijt is wél een bestanddeel bij een aantal specifieke vormen van mensenhandel (zie hierna bij de onderdelen $6^{\circ}$ tot en met $9^{\circ}$ ).

De ontwerprichtlijn introduceert twee nieuwe vormen van uitbuiting: (I) 'forced labour or services, including begging' en (2) 'exploitation of criminal activities'. ${ }^{159}$

Ten slotte past hier nog een opmerking over de zogenoemde 'non-punishment clause'. In artikel 26 van het Verdrag van de Raad van Europa ter bestrijding van mensenhandel en artikel 7 van de ontwerprichtlijn is het 'non-punishment'-beginsel neergelegd. Ingevolge deze bepaling moeten partijen respectievelijk lidstaten voorzien in de mogelijkheid dat geen straf wordt opgelegd aan (verdrag) respectievelijk geen vervolging wordt ingesteld tegen of straf wordt opgelegd aan (ontwerprichtlijn)

I55 S. Lestrade en W. ten Kate, 'De strafbaarstelling van 'overige uitbuiting' binnen mensenhandel', NJCM-bulletin, jr. 4 (2009), nr. 8, p. 858 en 869; Coster van Voorhout, a.w., p. 59 e.v.

I56 Zie uitgebreid over mensenhandel ten aanzien van organen NRM 5, hoofdstuk 9 en NRM 7 , hoofdstuk I3.

I57 Kamerstukken II 2003/04, 29 29I, nr. 3, p. I9.

I58 Zie Coster van Voorhout, a.w., p. 66. Vgl. artikel I97a lid 2 Sr: voor strafbaarheid van hulp bij illegaal verblijf is winstbejag een vereiste.

I59 Bedelarij is een vorm van - ongewone - arbeid. De toevoeging van bedelarij moet worden verstaan als gedwongen bedelarij. Het verrichten van criminele activiteiten is het verrichten van - illegale - arbeid of diensten. Het uitbuiten van bedelarij en van criminele activiteiten valt derhalve reeds onder artikel $273 \mathrm{flid} 2 \mathrm{Sr}$. Niettemin is het verstandig als de wetgever beide vormen toevoegt in lid 2. 
een slachtoffer van mensenhandel voor betrokkenheid bij onrechtmatige handelingen respectievelijk criminele activiteiten waartoe het slachtoffer is gedwongen. Het betreft bescherming tegen strafrechtelijke vervolging voor het plegen van strafbare feiten die verband houden met de uitbuitingssituatie waarin een slachtoffer van mensenhandel verkeert. Daarbij kunnen grofweg twee soorten strafbare feiten worden onderscheiden.

In de eerste plaats uitbuiting in criminaliteit. Daarbij worden slachtoffers gedwongen tot het plegen van strafbare feiten zoals zakkenrollerij, drugssmokkel en - afhankelijk van de nationale strafwetgeving - bijvoorbeeld ook bedelarij en prostitutie. Het zijn criminele vormen van arbeid of diensten, waarvan het plegen voorwerp is van uitbuiting. In de tweede plaats strafbare feiten waarvan het plegen geen voorwerp is van uitbuiting, maar die wel zijn 'afgedwongen' als gevolg van uitbuiting. Daarbij kan worden gedacht aan een slachtoffer dat zich onder dwang van de uitbuiter bedient van een vals identiteitsbewijs.

In de Nederlandse praktijk maakt het openbaar ministerie gebruik van de mogelijkheid om zaken waarin vervolging op grond van voornoemd beginsel niet opportuun wordt geacht, te seponeren. Voorts voorziet artikel ga Sr in de mogelijkheid van schuldigverklaring zonder oplegging van straf, als strafzaken van deze aard aan het oordeel van de rechter zouden worden onderworpen.

\subsubsection{Artikel 273 flid 1 , onderdeel $4{ }^{\circ}$}

We zullen nu eerst onderdeel $4^{\circ}$ bespreken, omdat deze bepaling thematisch aansluit bij het tweede lid. Onderdeel $4^{\circ}$ stelt als gezegd uitbuiting zelf strafbaar, zij het dat het woord 'uitbuiting' niet wordt gebezigd. De bepaling strekt niet tot uitvoering van internationale regelgeving. Het is een nationale verworvenheid. Zij past wel geheel in het doel van deze instrumenten: een brede en alomvattende strafrechtelijke aanpak van mensenhandel. Onderdeel $4^{\circ}$ voorziet in de strafrechtelijke bescherming tegen het dwingen of bewegen van een persoon zich beschikbaar te stellen tot het verrichten van arbeid of diensten of zijn organen beschikbaar te stellen. Alle vormen van uitbuiting, genoemd in artikel $273 \mathrm{f}$ lid $2 \mathrm{Sr}$, zijn in de kern (gericht op) gedwongen arbeid en diensten. Onderdeel $4^{\circ}$ maakt gebruik van de ingrediënten van artikel $273 \mathrm{flid} \mathrm{I}$, onderdeel $\mathrm{I}^{\circ}$, Sr.

De bepaling bestaat uit drie onderdelen.

a. Handelingen van de dader: een ander met de onder $1^{\circ}$ genoemde middelen dwingen of bewegen/onder de onder $1^{\circ}$ genoemde omstandigheden enige handeling ondernemen waarvan de dader weet of redelijkerwijs moet vermoeden

Het eerste gedeelte ziet op de dader die met ongeoorloofde middelen het slachtoffer brengt tot het zich beschikbaar stellen tot het verrichten van arbeid of diensten. In het midden wordt gelaten op welke middelen 'dwingen' of 'bewegen' betrekking heeft. ${ }^{160}$

I60 Zie noot 129 . 
Het tweede gedeelte 'onder de onder $I^{\circ}$ genoemde omstandigheden ... organen beschikbaar stelt' is ontleend aan artikel $250 a$ lid I, onderdeel I (oud) Sr, en zijn voorganger, artikel 25 oter lid I, onderdeel Iº, (oud) Sr. Blijkens de in hoofdstuk 2.I.5 beschreven wetsgeschiedenis ziet dit onderdeel op degene die in een (door een ander gecreëerde) uitbuitingssituatie of situatie van onvrijwilligheid (dat zijn de onder $\mathrm{I}^{\circ}$ genoemde omstandigheden waarbij een ongeoorloofd middel is gebruikt) enige handeling - welke dan ook - onderneemt waarvan hij of zij weet of redelijkerwijs moet vermoeden dat die ander zich daardoor beschikbaar stelt tot het verrichten van arbeid of diensten. ${ }^{161}$

b. Middel of omstandigheid: met een van de in onderdeel $1^{\circ}$ genoemde middelen dwingen of bewegen.../onder de onder onderdeel $1^{\circ}$ genoemde omstandigheden ${ }^{162}$ enige handeling ondernemen...

Wat in hoofdstuk 4.2.2 omtrent middelen is vermeld, geldt ook hier.

c. Handelingen van het slachtoffer: (dwingen of bewegen) zich beschikbaar te stellen tot het verrichten van arbeid en diensten of zijn organen ter beschikking stellen/handeling onderneemt waarvan de dader redelijkerwijs weet of moet vermoeden dat die ander zich daardoor beschikbaar stelt tot het verrichten van arbeid of diensten of zijn organen ter beschikking stelt

Onderdeel $4^{\circ}$ ziet op alle arbeid en diensten, waaronder seksuele dienstverlening. In de seksindustrie geschiedt seksuele dienstverlening tegen betaling door de klant. Anders dan in de onderdelen $3^{\circ}, 5^{\circ}$ en $8^{\circ}$ is het bestanddeel 'tegen betaling' hier niet opgenomen.

De klant als afnemer van seksuele diensten valt niet onder dit onderdeel (zie hierna ook de hoofdstukken 5.3 en 6.2). Handelingen van de klant kunnen vallen onder de zedenmisdrijven. ${ }^{163}$

Onderdeel $4^{\circ}$ betreft uitbuiting zowel in legale als in illegale activiteiten. Het is geen vereiste dat de arbeid of dienst daadwerkelijk wordt verricht. Het gaat erom dat het slachtoffer zich daartoe beschikbaar stelt. Zulks kan natuurlijk wel worden afgeleid uit daadwerkelijk verrichte arbeid of diensten.

I6I Kamerstukken II I988/89, 2I 027, nr. 3, p. 4: 'Onder toepassing van de het nu voorgestelde artikel 25oter Sr zullen bovendien ook diegenen vallen die gebruik makend van een uitbuitingssituatie enige handeling ondernemen waarvan hij of zij weet of redelijkerwijs moet vermoeden dat die ander daardoor in de prostitutie belandt.' Zie ook het in noot 56 gegeven voorbeeld.

I62 De verwijzing naar de onder $I^{\circ}$ genoemde omstandigheden betreft alle omstandigheden, niet slechts de 'feitelijke omstandigheden' waaruit misbruik van overwicht voortvloeit.

I63 Zie de artikelen 242 (verkrachting), 243 (gemeenschap met een wilsonbekwame), 244 (gemeenschap met een persoon onder I2 jaar), 245 (ontuchtige gemeenschap met een persoon onder I6 jaar), 246 (aanranding), 247 (ontucht met een wilsonbekwame of een persoon onder 16 jaar), 248 a (verleiding van een persoon onder I 8 jaar), 248 b (seks met een prostituee van I 6 en 17 jaar), $248 \mathrm{c}$ (opzettelijk aanwezig zijn bij ontuchtige handelingen van een persoon onder I8 jaar) of 249 (ontucht met een persoon onder i8 jaar, die onder gezag staat). Mensenhandelaren vergrijpen zich niet zelden aan hun slachtoffers. Zie over seksuele uitbuiting door één persoon buiten de seksindustrie NRM 7, p. 538. 
Onderdeel $4^{\circ}$ betreft het - met ongeoorloofde middelen - brengen of houden ${ }^{164}$ van het slachtoffer in een positie waarin hij zich beschikbaar stelt tot het verrichten van arbeid en diensten. Dat is dwingen in ruime zin tot het verrichten arbeid of diensten, dat is uitbuiting. ${ }^{165}$

Bij de bepaling van de door onderdeel $4^{\circ}$ geboden beschermingsomvang is het goed nog eens stil te staan bij de ontstaansgeschiedenis van deze bepaling. Deze bepaling - als artikel 250 a lid I, onderdeel $\mathrm{I}^{\circ}$, (oud) $\mathrm{Sr}$ - zag aanvankelijk alleen op prostitutie en later ook op overige seksuele dienstverlening. In dergelijke gevallen wordt uitbuiting verondersteld. Daar is de inbreuk op de lichamelijke en geestelijke integriteit immers steeds een gegeven. In 2004 is seksuele uitbuiting als gezegd uitgebreid met overige uitbuiting, namelijk gedwongen of verplichte arbeid, dienstbaarheid, slavernij en met slavernij te vergelijken praktijken. De inhoud van artikel $250 a$ lid I, onderdeel I ${ }^{\circ}$, (oud) $\mathrm{Sr}$ is herschreven in artikel $273 \mathrm{flid} \mathrm{I}$, onderdeel $4^{\circ}$. De strekking en context van de bepaling zijn evenwel dezelfde gebleven. Die zijn strafbaarstelling van uitbuiting. In de rechtsgeleerde literatuur is erop gewezen dat de redactie van onderdeel $4^{\circ}$ ruimte biedt voor een ruime uitleg die de context van uitbuiting te buiten gaat en waarbij gedrag onder het onderdeel komt te vallen dat niet als uitbuiting kan worden aangemerkt:

'Dus ook degene die een ander door fraude en misleiding ertoe brengt asperges te gaan steken of huishoudelijk werk te verrichten is strafbaar aan mensenhandel. Dit gaat wel erg ver. Te denken valt bijvoorbeeld aan eetpiraten die door misleiding horecapersoneel ertoe brengen zich beschikbaar te stellen voor het verrichten van diensten aan de eetpiraat.' ${ }^{166}$

Er zijn drie argumenten waarom dit onderdeel niet te ver is doorgeschoten: (I) De context en de strekking ervan, (2) het dwingen of bewegen tot het zich beschikbaar stellen tot het verrichten van arbeid en diensten, hetgeen niet wijst op het verrichten van eenmalige arbeid of dienstverlening ${ }^{167}$, en (3) de samenhang met onderdeel $\mathrm{I}^{\circ}$ waarin het oogmerk mede op gedwongen arbeid en diensten is gericht.

Onderdeel $4^{\circ}$ beoogt naar ons oordeel niet meer te omvatten dan wat valt onder lid 2. Bij beantwoording van de vraag of de ten laste gelegde feiten vallen onder onderdeel $4^{\circ}$ is niet nodig om vast te stellen onder welke van de in lid 2 genoemde vormen van uitbuiting deze feiten kunnen worden gebracht.

I64 HR I9 mei I992 NJ I992, 7I6; HR 6 juli I999, NJ I999, 70I; HR I8 april 2000, NJ 2000, 443.

I65 Vgl. Rechtbank Den Haag 3 mei 20I0, LJN: BM3374, overweging 3.5.3, ad b: 'Hoewel artikel $273 \mathrm{f}$ lid I, onder 4 Sr niet expliciet "uitbuiting" noemt, dient, wil aan de delictsomschrijving zijn voldaan, gelet op de strekking van deze bepaling wel sprake te zijn van het zich beschikbaar stellen tot het verrichten van arbeid in een situatie die als uitbuiting kan worden gekenschetst.'

I66 Zie N-L-R aantekening 6 bij artikel 273 flid I onder 4 Sr.

I67 In de memorie van toelichting bij het wetsvoorstel regulering prostitutie en bestrijding misstanden seksbranche wordt ook het standpunt ingenomen dat 'het zich beschikbaar stellen' duidt op een structurele situatie, waar incidentele handelingen buiten vallen, zie Kamerstukken II 2009/IO, 32 2II, nr. 3, p. 44. 


\subsubsection{Artikel 273flid 1, onderdeel $2^{\circ}$}

In onderdeel $2^{\circ}$ zijn de internationaalrechtelijke bepalingen inzake kinderhandel geïmplementeerd. Een kind is een persoon onder 18 jaar. ${ }^{168}$

Onderdeel $2^{\circ}$ volgt het stramien van onderdeel $\mathrm{I}^{\circ}$. Strafbaar zijn dezelfde handelingen met hetzelfde oogmerk, maar zonder het bestanddeel van de ongeoorloofde middelen. De handelingen zijn gericht op uitbuiting van kinderen en de verwijdering van organen van een kind.

Het element van onvrijwilligheid zit wél begrepen in uitbuiting. In 4.2 .3 is de vraag opgeworpen of 'onvrijwilligheid' relevant is voor beantwoording van de vraag of er sprake is uitbuiting van kinderen. Uitgangspunt is het bieden van een brede beschermingsomvang aan kinderen. Bij een kind wordt eerder een uitbuitingssituatie verondersteld dan bij een volwassene. Maar het element 'onvrijwilligheid' kan bij uitbuiting van een kind niet zonder meer worden losgelaten. Onvrijwilligheid wordt steeds relevanter naarmate het kind ouder wordt en het werk kindvriendelijker. Aan de omstandigheid dat het vereiste van onvrijwilligheid niet geldt voor de in onderdeel $2^{\circ}$ genoemde handelingen kan geen argument worden ontleend voor de stelling dat 'onvrijwilligheid' bij uitbuiting van kinderen geen rol speelt. In dit verband wordt verwezen naar hoofdstuk 4.2.7.

Het bestanddeel 'persoon onder I8 jaar' is in dit onderdeel en de onderdelen $5^{\circ}$ en $8^{\circ}$ geheel geobjectiveerd. ${ }^{169}$ De kinderhandelaar handelt op eigen risico als hij zich niet vergewist van de leeftijd van de (jonge) persoon.

\subsubsection{Artikel 273 flid 1, onderdeel $3^{\circ}$}

Onderdeel $3^{\circ}$ beoogt het gesleep van kwetsbare personen van het ene land met het oog op seksuele uitbating in een ander land tegen te gaan. De bepaling stelt strafbaar het aanwerven, medenemen of ontvoeren van een persoon in het ene land met het oogmerk die persoon in een ander land ertoe te bewegen zich beschikbaar te stellen tot het verrichten van seksuele handelingen met of voor een derde tegen betaling. Dit onderdeel gaat - door de verbreding tot andere vormen van seksuele dienstverlening dan prostitutie - verder dan waartoe het Verdrag van Genève van I933 verplicht. Het oogmerk betreft alle vormen van seksuele dienstverlening tegen betaling. Het vereiste van onvrijwilligheid als zodanig geldt hier niet. In 'ontvoeren' zit natuurlijk wél een element van onvrijwilligheid. De bepaling is een vreemde eend in de bijt, nu zij ook ziet op vrijwillige seksuele dienstverlening door volwassenen. Seksexploitanten die in het buitenland (buitenlandse) sekswerkers benaderen en bewegen naar Nederland te komen met het oog op hun - overigens legale - seksuele uitbating, zijn strafbaar. In deze bepaling komt mede het respect van Nederland voor het strafrechtelijke regime in een ander land met betrekking tot prostitutie tot uitdrukking. De verwachting van de wetgever dat deze bepaling nauwelijks

I68 In de Nederlandse zedelijkheidswetgeving is 'minderjarige' steeds vervangen door 'een persoon die de leeftijd van achttien jaar nog niet heeft bereikt'. Zie ook noot Io6.

I69 Objectivering van de leeftijd van kinderen geldt ook voor de artikelen 244, 245, 247 en $248 \mathrm{~b} \mathrm{Sr}$. 
toepassing zou vinden, is niet uitgekomen. Zij wordt in de rechtspraktijk nogal eens toegepast. ${ }^{170}$ Daaruit blijkt naar onze mening haar nuttige aanvullende werking.

\subsubsection{Artikel 273flid 1, onderdeel $5^{\circ}$}

Onderdeel $5^{\circ}$ ziet op specifieke uitbuiting van een kind. Dit onderdeel is geënt op onderdeel $4^{\circ}$. Evenals in onderdeel $2^{\circ}$ geldt ook hier het vereiste van onvrijwilligheid niet. Maar juist hierin schuilt de beperking ten opzichte van onderdeel $4^{\circ}$. Onderdeel $5^{\circ}$ is beperkt tot seksuele dienstverlening en orgaanverwijdering tegen betaling. De wetgever acht in het kader van kinderhandel waarbij het vereiste van 'onvrijwilligheid' is losgelaten, alleen deze vormen van uitbating van een kind uitbuiting. Voor de overige vormen van arbeid en dienstverlening moet men terugvallen op het algemeen geldende onderdeel $4^{\circ}$, waarvoor het element van onvrijwilligheid wél geldt.

Het bewegen van kinderen tot het hebben van seks met een ander zonder meer - dat wil zeggen zonder het bestanddeel 'tegen betaling' - is elders strafbaar gesteld. ${ }^{17 \mathrm{I}}$

Strafbaarstelling van uitbating van kinderen die vrijwillig andere voor kinderen onwenselijke arbeid of diensten verrichten, dient te geschieden in het kader van de bestrijding van onwenselijke kinderarbeid. Die uitbating behoort niet meer tot het domein van mensenhandel. Het bewegen van een kind om zijn organen om niet ter beschikking te stellen is niet zonder meer strafbaar en valt buiten het bereik van mensenhandel.

\subsubsection{Artikel 273 flid 1 , onderdelen $6^{\circ}$ en $7^{\circ}$}

In onderdeel $6^{\circ}$ is het opzettelijk profiteren van uitbuiting van een ander strafbaar gesteld en in onderdeel $7^{\circ}$ het opzettelijk profiteren van orgaanverwijdering van een ander onder ongeoorloofde omstandigheden. Anders dan bij de onderdelen $I^{\circ}$ tot en met $5^{\circ}$ is profijt hier bestanddeel. De bepaling ziet op achtergronddaders die niet (zonder meer) via deelneming aan de in de onderdelen $\mathrm{I}^{\circ}$ tot en met $5^{\circ}$ omschreven feiten kunnen worden aangepakt. ${ }^{172}$ Met 'uitbuiting' wordt gedoeld op de in het tweede lid omschreven vormen van uitbuiting. Uit het opzetvereiste volgt dat de dader zich in ieder geval bewust moet zijn van de relevante omstandigheden waaruit uitbuiting voortvloeit. Voorwaardelijk opzet is toereikend. Het is niet nodig om een keuze te maken uit een van de vormen van uitbuiting. Voldoende is dat de wezenskenmerken van een van die vormen van uitbuiting aanwezig zijn.

Onderdeel $7^{\circ}$ relateert het profijt aan orgaanverwijdering onder de onder $\mathrm{I}^{\circ}$ genoemde omstandigheden. Denkbaar zou zijn geweest om in onderdeel $6^{\circ}$ het

I70 Zie NRM 7, hoofdstuk II.4.2.

I7I Zie de artikelen 247 en 250 Sr.

I72 De memorie van toelichting bij wetsvoorstel 29 29I drukt zich wat ongelukkig uit: 'Voor een effectieve bestrijding van mensenhandel is het immers wenselijk dat niet alleen de mensenhandelaren zelf, maar ook de uitbaters van de uitbuiting waarop mensenhandel is gericht, uitdrukkelijk strafbaar worden gesteld en daardoor effectief kunnen worden aangepakt.' Het gaat in de onderdelen $6^{\circ}$ en $7^{\circ}$ om profiteurs van uitbuiting. 
profijt niet te relateren aan 'uitbuiting', maar ook aan deze omstandigheden en om de beide onderdelen tezamen in één onderdeel op de leest van artikel $250 \mathrm{a}$ lid I, onderdeel $4^{\circ}$, (oud) te schoeien. ${ }^{173}$

\subsubsection{Artikel 273flid 1, onderdeel $8^{\circ}$}

Dit onderdeel stelt strafbaar het opzettelijk voordeel trekken uit seksuele handelingen van een persoon onder 18 jaar met of voor een derde tegen betaling of uit de verwijdering van diens organen tegen betaling. De gronden voor deze beperking zijn dezelfde als bij onderdeel $5^{\circ}$.

\subsubsection{Artikel 273 lid 1, onderdeel $9^{\circ}$}

Dit onderdeel ziet op de onvrijwillige afdracht van de opbrengst uit (vrijwillige) seksuele dienstverlening en orgaanverwijdering. Het bestanddeel 'tegen betaling' is niet opgenomen. Dit bestanddeel zit begrepen in de 'opbrengst'. De onvrijwilligheid vloeit voort uit de in onderdeel $\mathrm{I}^{\circ}$ genoemde middelen.

De onvrijwillige afdracht van de opbrengst van overige arbeid en diensten is strafbaar gesteld in artikel 284 Sr inzake dwang.

$\mathrm{Nu}$ het opzettelijk profijt trekken van uitbuiting reeds strafbaar is gesteld in onderdeel $6^{\circ}$, is het niet nodig om ook de onvrijwillige afdracht van de opbrengst van in een uitbuitingssituatie verrichte arbeid of diensten strafbaar te stellen.

\subsubsection{Artikel 273fleden 3 tot en met 5}

Het derde tot en metvijfde lid voorziet in oplopende strafmaxima voor mensenhandel onder in ernst oplopende strafverzwarende omstandigheden (betrokkenheid van twee of meer daders of van een slachtoffer onder de I6 jaar, zwaar lichamelijk letsel of levensgevaar en dood). ${ }^{174}$ Deze omstandigheden hebben dus geen betrekking op de aard van de uitbuiting (bijvoorbeeld slavernijachtige praktijk of dienstbaarheid), of de aard van de arbeid of dienst (bijvoorbeeld seksuele uitbuiting). Het zesde lid verklaart artikel 25I Sr inzake bijkomende straffen van overeenkomstige toepassing. Deze onderdelen behoeven geen nadere bespreking.

I73 Bijvoorbeeld: Degene die opzettelijk voordeel trekt uit arbeid of diensten van een ander of de verwijdering van organen van een ander, terwijl hij weet of redelijkerwijs moet vermoeden dat die ander zich onder de onder $\mathrm{I}^{\circ}$ genoemde omstandigheden beschikbaar stelt tot het verrichten van arbeid of diensten of zijn organen beschikbaar stelt.

I74 Vermelding verdient dat in de ontwerp richtlijn een strafverzwaringsgrond is opgenomen voor alle vormen van mensenhandel gepleegd tegen een kind (iedere persoon beneden de leeftijd van achttien jaar). De regering heeft reeds het voornemen aangekondigd om artikel $273 \mathrm{f} \mathrm{Sr}$ op dit punt te wijzigen, zie Kamerstukken II 2009/10, 3I oor, nr. 76, p. 2. 


\subsection{Onvrijwilligheid en uitbuiting nader bekeken}

\subsubsection{Inleiding}

Na bespreking van artikel $273 \mathrm{f}$ Sr is het zinvol nog eens stil te staan bij de twee kernen van mensenhandel: onvrijwilligheid en uitbuiting. Onvrijwilligheid ligt besloten in uitbuiting. Onvrijwilligheid omvat twee kanten: ongeoorloofde beïnvloeding door de dader én een ontvankelijkheid en conditionering van het slachtoffer daarvoor. Uitbuiting is het onvrijwillig laten verrichten van werk. Uitbuiting vindt plaats in een uitbuitingssituatie. Die situatie kan uitbuiting conditioneren. 'Uitbuitingssituatie' is een feitelijk begrip.

De ongeoorloofde middelen zijn neergelegd in artikel $273 \mathrm{flid} \mathrm{I}$, onderdeel I ${ }^{\circ}$. Uitbuiting is omschreven in artikel 273 flid 2. Uitbuiting - in andere bewoordingen - is strafbaar gesteld in artikel $273^{\mathrm{flid}} \mathrm{I}$, onderdelen $4^{\circ}$ en $5^{\circ}$. Uitbuiting wordt afgeleid uit omstandigheden die wijzen op ongeoorloofde beïnvloeding en op een uitbuitingssituatie. Voor beantwoording van de vraag of er sprake is van uitbuiting is het niet nodig dat wordt bepaald welke van de in lid 2 genoemde vormen van uitbuiting in het geding is. ${ }^{175} \mathrm{Bij}$ alle vormen van uitbuiting speelt immers steeds een element van onvrijwilligheid. Die onvrijwilligheid wordt afgeleid uit het gebruik van ongeoorloofde middelen, bedoeld in onderdeel $\mathrm{I}^{\circ}$.

De opsporing, vervolging en berechting van mensenhandelaren en uitbuiters zijn moeilijk. Mensenhandelzaken zijn - mede vanwege hun vaak internationale dimensie - ingewikkeld en tijdrovend, de scheidslijnen tussen onvrijwilligheid en vrijwilligheid zijn vloeiend, en slachtoffers zijn niet steeds in staat of bereid hun medewerking te verlenen aan de opsporing.

De rechtspraktijk bedient zich bij mensenhandelzaken van indicatoren of kenmerken van mensenhandel. Deze moeten de praktijk een handreiking bieden bij de beantwoording van de vraag of vervolging voor mensenhandel is geïndiceerd. ${ }^{176}$ De Nationaal Rapporteur Mensenhandel maakt gebruik van vier indicatoren van een mogelijke situatie van overige uitbuiting: dwang/misleiding, slechte arbeidsomstandigheden, onvrijheid en meervoudige afhankelijkheid. ${ }^{177}$

I75 Vgl. EHRM in de zaak Rantsev tegen Cyprus en Rusland, par. 282 (zie hoofdstuk 3.3).

I76 Zie bijlage 3 bij de Aanwijzing mensenhandel (Stcrt. 2008, 253). Deze bijlage is opgenomen als bijlage 2 bij dit preadvies. Voorts zij gewezen op de brochure 'Arbeid en uitbuiting' (januari 20Io), een uitgave van het ministerie van Sociale Zaken en Werkgelegenheid. De brochure noemt een aantal omstandigheden. Bij aanwezigheid van twee of meer van die omstandigheden is sprake van een indicatie van uitbuiting. Het gaat om: gedwongen worden om gevaarlijk of ongezond werk te doen, niet beschikken over het eigen paspoort of reisdocumenten, het moeten afbetalen van een hoge schuld aan de werkgever, niet of heel weinig betaald krijgen voor het te verrichten werk, mishandeld, gechanteerd of bedreigd worden, de werkgever dreigt aangifte te doen wegens illegaal verblijf in Nederland, beperking van de bewegingsvrijheid buiten werktijd, bij ziekte niet naar de dokter of het ziekenhuis mogen.

I77 NRM 5, p. 213: (I) dwang/misleiding (fysiek geweld tegen de werknemer of dreiging daarmee, (dreiging met) melden van illegaal verblijf van werknemer, werknemer wordt op ontoelaatbare 
De Nationaal Rapporteur Mensenhandel geeft in haar zevende rapportage een fraai en uitgebreid (rechtsvergelijkend) overzicht van de rechtspraak op de drie terreinen van mensenhandel. ${ }^{178}$ Lestrade en Ten Kate gaan uitvoerig in op de rechtspraak in de zogenoemde overige uitbuiting. ${ }^{179}$ Ook kan worden verwezen naar de literatuurstudie van Van der Leun en Vervoorn over slavernijachtige uitbuiting in Nederland. ${ }^{180}$

Uit het onderzoek van de Nationaal Rapporteur Mensenhandel en het artikel van Lestrade en Ten Kate blijkt dat de rechtspraktijk heeft geworsteld met de toepassing van artikel $273 \mathrm{f}$ Sr wat betreft de kernbegrippen onvrijwilligheid en uitbuiting, in het bijzonder op het terrein van de overige uitbuiting. Dat is niet vreemd, omdat op dat terrein het onderscheid tussen uitbuiting enerzijds en slecht werkgeverschap anderzijds óf tussen strafwaardige en onfatsoenlijke uitbating als gezegd niet altijd helder is. ${ }^{\mathrm{I} I}$ De lagere rechtspraak blijkt in navolging van de literatuur ${ }^{182}$ tot nu toe de lat hoog, soms te hoog te hebben gelegd. Voor een veroordeling voor mensenhandel in de overige uitbuiting moet er volgens die rechtspraak sprake zijn van een exces, van excessief misbruik. Van een exces is pas sprake als het slachtoffer in zulke slechte omstandigheden verkeert en tewerkgesteld wordt dat hij in zijn fundamentele mensenrechten - menselijke waardigheid, lichamelijke integriteit, persoonlijke vrijheid - wordt of dreigt te worden geschonden. Soms moet er zelfs

wijze onder druk gezet, tewerkstelling in een andere sector of onder andere omstandigheden dan afgesproken, misbruik maken van het gebrek aan kennis van de eigen (rechts)positie); (2) slechte werkomstandigheden (gedwongen gevaarlijk werk, onredelijke werktijden, werknemer krijgt niet of minder dan minimumloon betaald, ook bij ziekte moet worden gewerkt; (3) onvrijheid (werkgever/tussenpersoon heeft de (reis) documenten van de werknemer ingenomen, werknemer mag niet of nauwelijks contact onderhouden met de buitenwereld); (4) meervoudige afhankelijkheid (werknemer is door een schuld aan werkgever of tussenpersoon gebonden, werknemer is voor bij voorbeeld onderdak, eten of documenten afhankelijk van de werkgever.

I78 NRM 7, hoofdstukken II (jurisprudentie inzake uitbuiting in de seksindustrie), I2 (uitbuiting in andere sectoren dan de seksindustrie) en I2 (mensenhandel met het oogmerk van orgaanverwijdering).

I79 S. Lestrade en W. ten Kate, a.w., p. 852.

I80 J. Van der Leun en L. Vervoorn, Slavernij-achtige uitbuiting in Nederland, een inventariserende literatuurstudie in het kader van de uitbreiding van de strafbaarstelling van mensenhandel, 2004, Boom juridische uitgevers, Den Haag. Uit die studie blijkt dat een belangrijk criterium voor de beoordeling van deze uitbuiting gelegen is in een sterke inperking van de vrije keuze. Uit de literatuur komt een aantal kenmerken naar voren: meervoudige afhankelijkheid van de werkgever (deze regelt ook huisvesting, kleding, vervoer, of is schuldeiser van de werknemer), een sterke inperking van basisvrijheden van de werknemer (deze kan of mag bijvoorbeeld geen contact hebben met de buitenwereld, heeft geen beschikking over eigen identiteitspapieren, geen beschikking over eigen inkomsten), gebrek aan informatie over de eigen positie (werknemer is bijvoorbeeld misleid over de aard van het werk of over verdiensten), arbeid of dienstverlening onder zeer slechte arbeidsomstandigheden (werknemer ontvangt bijvoorbeeld een ongebruikelijk laag loon, werkt onder gevaarlijke omstandigheden, uitzonderlijke lange werkdagen of werkweken), aantasting van de lichamelijke integriteit (afstaan van organen, onvrijwillige tewerkstelling in de prostitutie, geweld of bedreiging daarmee), uitbuiting is niet incidenteel, maar vertoont een patroon of vindt plaats in enigerlei georganiseerd verband.

I8I H. De Jonge van Ellemeet, 'Slecht werkgeverschap of moderne slavernij, Handhaving van een nader af te bakenen verbod', Justitiële verkenningen (JV 7/2007, p. I07). Zie ook NRM 7, p. 509. Zie ook het door NRM gehanteerd criterium om uitbuiting te onderscheiden van andere misstanden: 'er is sprake van dwang, van slechte arbeidsvoorwaarden of -omstandigheden of van meervoudige afhankelijkheid én het slachtoffer heeft niet de vrijheid of meent die redelijkerwijs niet te hebben om uit de arbeidssituatie te stappen.' (NRM 7, p. 55I).

I82 Zie bijvoorbeeld Smit/Boot, t.a.p., p. I6. 
sprake zijn van een ernstige inbreuk - één ernstige inbreuk of een cumulatie van minder ernstige inbreuken - op mensenrechten. Misbruik zonder meer wordt niet toereikend geacht. De rechtspraak op het terrein van de overige uitbuiting is streng geweest, zowel in zaken die tot een veroordeling hebben geleid als in vrijspraken. Veroordelingen zijn tot nu toe spaarzaam geweest. ${ }^{1{ }^{83}}$

\subsubsection{HR 27 oktober 2009 en conclusie AG Knigge}

De Hoge Raad en advocaat-generaal Knigge hebben de rechtspraktijk en -wetenschap verrijkt met een richtinggevende uitspraak en conclusie. ${ }^{184}$ Het is daarom zinvol en gerechtvaardigd hierop wat dieper en uitvoeriger in te gaan.

De zaak betreft overige uitbuiting van illegale Chinezen die werken in een restaurant in ruil voor kost en inwoning dan wel voor een maandinkomen van tussen $€ 450$ en $€ 800$ met werkdagen van II en I3 uur en met niet meer dan vijf vrije dagen per maand. Zij moeten hun - boven het restaurant gelegen - slaapkamer delen met verschillende anderen. In deze zaak gaat het om de toepassing en uitleg van artikel 273a lid I, onderdeel I ${ }^{\circ}$, (oud) Sr.

\section{Het Hof Den Bosch}

Het hof gaat eerst in op de vraag of er sprake is van handelen met een van de ongeoorloofde middelen en beperkt zich daarbij tot de vraag of er sprake is van misbruik van uit feitelijke omstandigheden voortvloeiend overwicht dan wel misbruik van een zwakkere/kwetsbare positie, aangezien van dwang, (dreiging met) een of meer feitelijkheden of misleiding niet was gebleken.

Het hof komt met de eerste rechter tot het oordeel dat de ten laste gelegde feiten niet kunnen worden bewezen. Het hof is met de eerste rechter van oordeel dat zulk misbruik, gelet op de wetsgeschiedenis en de redactie van artikel 273 a (oud) Sr, een zeker initiatief en actief handelen van de dader vooronderstelt, waarbij hij doelbewust misbruik heeft gemaakt van de zwakkere of kwetsbare positie van slachtoffers. Pas als dat misbruik kan worden vastgesteld, moet worden beoordeeld of een en ander is geschied met het oogmerk van uitbuiting.

I83 Rechtbank Haarlem 22 april 2007, LJN: BI35I9. Veroordeling op basis van artikel 273f lid I, onderdeel I ${ }^{\circ}$, Sr (een vrouw was gedwongen tot het vervoer van drugs naar Nederland waarbij met geweld cocaïnebollen in haar vagina en anus waren gebracht). Hof Leeuwarden 6 oktober 2009, LJN: BJ9385 (GGZ-patiënt). Het hof overwoog onder meer dat uit de internationale instrumenten inzake mensenhandel volgt dat de bescherming van mensenrechten centraal staat bij de aanpak van mensenhandel. Dit brengt met zich mee dat er pas dan sprake is van uitbuiting in de zin van artikel $273 \mathrm{f} \mathrm{Sr}$ als deze een inbreuk maakt op fundamentele rechten. Uit die instrumenten volgt dat niet ieder misbruik kan worden beschouwd als uitbuiting. Er moet sprake zijn van een exces, d.w.z. van een ernstige inbreuk op fundamentele mensenrechten. Voorts Rechtbank Utrecht I7 juni 2008, LJN: BD7426 (verstandelijk gehandicapte). De rechtbank gaat uit van een drietrapsraket: er is sprake van arbeid of diensten, van een uitbuitingssituatie en ten slotte van uitbuiting die zodanig is dat mensenrechten zijn geschonden. Rechtbank Den Haag I4 december 2007, LJN: BCirg5 en BCi76r: alle feiten en omstandigheden in onderling verband bezien wijzen op een excessieve situatie die als dienstbaarheid kan worden aangemerkt. Er is ook sprake van zekere dubbelheid (vrijwillige komst naar Nederland en dankbaarheid jegens de daders). Die doet echter niet af aan de feitelijke onmogelijkheid om eenmaal in Nederland te ontkomen aan een uitzichtloze situatie onder mensonterende omstandigheden.

I84 HR 27 oktober 2009, LJN: BI7099, zaak o8/03895. 
Het hof stelt voorop dat de Chinezen verkeren in een kwetsbare/zwakkere positie en dat zij illegaal waren. Het hof gaat verder uit van vijf feiten en omstandigheden: (I) de Chinezen hebben zelf de beslissing genomen om naar Nederland te komen, (2) zij hebben de reis ondernomen om hier geld te verdienen, (3) zij hebben zelf aan de uitbaters van het restaurant om werk, eten en onderdak gevraagd; sommigen hebben alleen gevraagd om eten en onderdak en hebben vrijwillig werkzaamheden verricht, (4) zij hebben geen (financiële) verplichtingen ten opzichte van die uitbaters en (5) het staat hen vrij op ieder moment te vertrekken. Verschillenden van hen hebben daarvoor al elders gewerkt.

Het hof constateert dat de verdachte niet het initiatief heeft genomen en ook niet actief heeft gehandeld, door bijvoorbeeld de Chinezen te benaderen en hen te overreden in het restaurant te komen werken. Hij heeft gereageerd op verzoeken, soms zelf op smeekbedes. Onder die omstandigheden kan niet worden bewezen dat verdachte bij het huisvesten of opnemen van de Chinezen doelbewust misbruik heeft gemaakt van het uit feitelijke omstandigheden voortvloeiend overwicht of van hun zwakkere/kwetsbare positie.

Vervolgens gaat het hof ten overvloede nog in op de vraag of er oogmerk van uitbuiting in het spel was. Het hof verwijst naar de wetsgeschiedenis over uitbuiting. ${ }^{185}$ Er is weliswaar sprake van een ongewenst geachte arbeidssituatie (lange werkdagen van II-I3 uur, vijf vrije dagen per maand, meerdere bedden op een slaapkamer, inkomen tussen 450 en 800 euro per maand), maar dat is nog geen uitbuitingssituatie als bedoeld in artikel 273 a (oud) Sr. Het hof neemt hierbij het volgende in aanmerking: niet is gebleken dat de werkomstandigheden op zichzelf (los van de lengte van de werkdagen) slecht waren, het verdiende inkomen stond geheel ter vrije beschikking (kost en inwoning waren gratis) en van geen van de Chinezen kan worden gezegd dat zij in hun situatie redelijkerwijs geen andere keuze hadden dan te werken en/of te verblijven in het restaurant.

Het middel klaagt erover dat het hof een onjuiste uitleg heeft gegeven aan de bestanddelen 'misbruik van uit feitelijke omstandigheden voortvloeiend overwicht' en 'misbruik van een kwetsbare positie' en dat de motivering voor het ontbreken van 'uitbuiting' ontoereikend is.

De conclusie van de advocaat-generaal

Aan de uitspraak van de Hoge Raad ligt een scherpzinnige en uitvoerige conclusie van AG Knigge ten grondslag. Deze is een preadvies op zichzelf. De conclusie gaat kritisch in op de relevante wettelijke bepalingen en op de wetsgeschiedenis en bouwt voort op eerdere rechtspraak en conclusies. $\mathrm{Zij}$ is prikkelend en vergt close reading. Een paar grepen daaruit. Wij beseffen dat met deze 'pick and choose'-techniek aan

I85 Kamerstukken II 2003/04, 29 29I, nr. 3, p. I8: 'Daarbij kan worden gedacht aan tewerkstelling onder dwang of het maken van misbruik van een afhankelijke positie van een persoon die onder de gegeven omstandigheden redelijkerwijs geen andere keuze had dan in een toestand van uitbuiting te geraken. Als voorbeeld kan worden genoemd een extreem lange werkweek tegen onevenredig lage betaling onder slechte werkomstandigheden.' 
de rijkdom van deze conclusie tekort wordt gedaan. De cijfers tussen haken verwijzen naar de paragrafen uit de conclusie.

Ten aanzien van onvrijwilligheid

De gedwongen handelingen (zoals vervoer of huisvesting) in artikel 273a lid I, onderdeel I ${ }^{\circ}$, Sr moeten instrumenteel zijn aan de beoogde uitbuiting (I5).

De eis van 'doelbewust' misbruik van overwicht vindt geen steun in de tekst van artikel 273 a lid I, onderdeel I, aldus Knigge:

'Het oogmerk dat van de dader wordt geëist, is gericht op de uitbuiting en niet op het misbruik dat wordt gemaakt. Grammaticaal gezien is er dus geen argument om als extra oogmerk te eisen dat het huisvesten geschiedt met het doel om misbruik te maken van de omstandigheden. Voor zover het vereiste middel (het misbruik dat gemaakt wordt van de bijzondere positie waarin de ander verkeert) een doel veronderstelt, is dat de huisvesting (die op haar beurt dient te geschieden met het oogmerk van uitbuiting). Het is dus niet andersom, dat het huisvesten tot doel heeft om misbruik te maken.' (2I)

$\mathrm{Na}$ het citeren van de hierna aangehaalde overwegingen 5.5 en 5.6 uit het arrest van de Hoge Raad van 5 februari 2002 merkt Knigge op dat de Hoge Raad in dit arrest voor het bewijs van 'misbruik' voorwaardelijke opzet voldoende acht (22).

Noch de ratio legis noch de wetsgeschiedenis van artikel 273a (oud) Sr biedt steun voor het stellen van de eis van initiatief en actief handelen door verdachte (24).

Vervolgens speelt Knigge op creatieve wijze met de begrippen onvrijwilligheid en vrijwilligheid:

'Door de eis te stellen dat het initiatief van de dader moet zijn uitgegaan, wordt in feite via de achterdeur binnengesmokkeld wat art. 3 sub b van het Palermo Protocol aan de voordeur heeft willen uitsluiten. Naar de letter genomen, is het oordeel van het Hof niet in strijd met genoemd art. 3 sub b. De instemming van het slachtoffer is volgens deze bepaling pas irrelevant, als gebruik is gemaakt van de genoemde dwangmiddelen. Het Hof oordeelt dat van gebruik van een dwangmiddel geen sprake is geweest (zodat art. 3 sub b van het Palermo Protocol niet in beeld is). Door evenwel misbruik van een kwetsbare positie te ontkennen op grond van het feit dat de slachtoffers zich vrijwillig meldden, wordt de strafbaarstelling nog in verdere mate ontkracht dan het geval is bij de uitholling waartegen art. 3 sub b van het Palermo Protocol beoogt te waken.' (25)

Als juist is wat de advocaat-generaal bij het hof over de uitbuitingssituatie heeft gezegd, blijft er naar het oordeel van Knigge van de vrijwilligheid waarop het hof zo zwaar leunde, weinig over. Als de slachtoffers geen kant op konden en in feite geen keus hadden, is het wrang om van een vrije wil te spreken. Personen die in een zo kwetsbare positie verkeren dat de exploitanten zelf geen initiatief hoeven te ontplooien om hen uit te buiten, verdienen de bescherming van de strafwet in de eerste plaats (27). 
Het oordeel van het hof dat is vereist dat de daders het initiatief nemen en hun slachtoffers actief benaderen, geeft volgens Knigge dus blijk van een onjuiste rechtsopvatting.

Ten aanzien van de uitbuiting

Knigge stuit daarbij op drie vragen met betrekking tot de uitleg van dit begrip.

De uitleg van het begrip uitbuiting moet worden bezien in het licht van de wetsgeschiedenis van artikel 273 a (oud) Sr en de internationale instrumenten die eraan ten grondslag liggen (32). Het ligt naar de mening van Knigge voor de hand om bij de uitleg van het bestanddeel 'gedwongen of verplichte arbeid of diensten, slavernij en met slavernij of dienstbaarheid te vergelijken praktijken' aansluiting te zoeken bij artikel 4 EVRM (33). Na uitvoerige citaten uit het in hoofdstuk 3.2 besproken arrest van het Hof van 26 juli 2005 (Siliadin tegen Frankrijk) komt Knigge tot de eerste vraag: is met de invulling van het Hof aan de begrippen 'slavery', 'servitude' en 'forced and compulsary labour' tevens de reikwijdte van artikel 273 a lid I, onderdeel $\mathrm{I}^{\circ}$, (oud) Sr bepaald? Is alleen sprake van de arbeidsuitbuiting die deze bepaling beoogt tegen te gaan, als de arbeidsomstandigheden een schending van artikel 4 EVRM opleveren (35)?

Knigge ziet in de literatuur ${ }^{186}$ een begin van een bevestigende beantwoording van die vraag. Artikel 273a (oud) Sr handelt blijkens die literatuur alleen over excessen. Een exces is een inbreuk op fundamentele mensenrechten. Als deze rechten (dreigen te) worden geschonden, is er sprake van excessief misbruik dat als uitbuiting in de zin van mensenhandel valt te bestempelen ( 36 en 37 ).

Knigge merkt op dat deze uitleg grote invloed op de rechtspraak lijkt te hebben gehad (38). Hij heeft op zich wel begrip voor de waarschuwing van een te ruime uitleg van het begrip uitbuiting, maar vraagt zich tegelijkertijd af of de Nationaal Rapporteur Mensenhandel niet te ver is doorgeschoten in de drang tot inperking. Als arbeidsuitbuiting beperkt blijft tot schending van artikel 4 EVRM, is zulks op gespannen voet met de tekst van artikel 273a lid 2 (oud) Sr, dat tot uitbuiting ook rekent 'met slavernij en dienstbaarheid te vergelijken praktijken' (die niet vallen onder artikel 4 EVRM). Bovendien bepaalt artikel 273a lid 2 (oud) Sr dat uitbuiting 'ten minste' de aldaar omschreven vormen omvat (39).

Iedere vorm van dwang maakt inbreuk op de persoonlijke vrijheid. De wetgever onderkent dat de strafbaar gestelde gedragingen in aard en ernst van elkaar verschillen en niet alle vormen van uitbuiting even ernstig behoeven te zijn (42).

Dan komt Knigge kernachtig tot een ontkennende beantwoording van de eerste vraag:

I86 A.G. Korvinus en D.A.C. Koster e.a., 'Mensenhandel; de achtergronden en omtrekken van het begrip uitbuiting in art. 273a Sr', Trema, 29e jrg., nr. 7, 2006, p. 286-290. NRM 5, p. 2 I. 
'Schendingen van artikel 4 EVRM vormen wel de kern van uitbuiting in arbeidssituaties, maar art. 4 EVRM begrenst de strafbaarstelling niet. Anders gezegd: als sprake is van "slavery", "servitude" en "forced and compulsary labour" in de zin van art. 4 EVRM, is steeds sprake van uitbuiting in de zin van art. 273 a (oud) Sr. Het omgekeerde is echter niet het geval: als er geen sprake is van een schending van art. 4 EVRM, kan toch sprake zijn van arbeidsuitbuiting. Ik zou art. 273 a lid 2 (oud) Sr daarbij zo willen uitleggen dat de zinsnede "ten minste" betrekking heeft op andere, niet met zoveel woorden genoemde vormen van uitbuiting. Te denken valt bijvoorbeeld aan de afgedwongen medewerking van proefpersonen aan onverantwoorde medische experimenten. De begrenzing van de strafbaarheid van de uitbuiting in arbeidssituaties dient zogezien gezocht te worden in de uitleg van "met slavernij of dienstbaarheid te vergelijken praktijken". Als er geen sprake is van een vergelijkbare praktijk, is geen sprake van arbeidsuitbuiting als bedoeld in art. 273 (oud) Sr. De betekenis van 'ten minste' is daarbij hooguit deze, dat bij de vraag of er sprake is van een vergelijkbare praktijk niet al te krampachtig te werk behoeft te worden gegaan. Vergelijkbaar wil niet zeggen dat de desbetreffende praktijk qua ernst op één lijn gesteld moet worden met een schending van art. 4 EVRM. Van vergelijkbaarheid is sprake als er op belangrijke punten overeenkomst is. Vergelijkbaarheid veronderstelt tegelijk ongelijkheid en daarmee verschillen. Zo'n verschil kan de ernst van de uitbuiting zijn.' (43)

Dan komt Knigge toe aan de tweede vraag: hoe miserabel moeten de arbeidsomstandigheden zijn, wil van uitbuiting sprake zijn? Knigge verwijst naar het voorbeeld: een extreem lange werkweek tegen onevenredig lage betaling onder slechte werkomstandigheden. ${ }^{187}$ Wat is 'extreem', 'onevenredig' en 'slecht', en aan welke maatstaf wordt dat afgemeten, aan de situatie in een derdewereldland of aan de Nederlandse situatie? (44).

De opvatting van de Nationaal Rapporteur Mensenhandel dat de situatie waarin de mondige arbeider in Nederland pleegt te verkeren, vertrek- en oriëntatiepunt zijn bij de vraag of er sprake is van uitbuiting, vindt op zich geen steun in de wetgeschiedenis en de rechtspraak. Die vergelijking heeft volgens Knigge geen betrekking op arbeidsomstandigheden, maar op de vraag of het slachtoffer zich bevindt in een afhankelijke positie waarvan misbruik kan worden gemaakt (45). Niettemin is het standpunt van de Nationaal Rapporteur Mensenhandel volgens Knigge juist:

'Dit in de eerste plaats omdat, als de Nederlandse wetgever woorden als "extreem", "onevenredig" of "slecht" in de mond neemt, het voor de hand ligt dat zijn referentiekader de Nederlandse situatie is. In de tweede plaats omdat dit standpunt mij in overeenstemming lijkt te zijn met de ratio legis. Het oogmerk van de mensenhandelaar is niet, of niet primair, om zijn slachtoffer onder beroerde omstandigheden te laten werken, maar om aan hem te verdienen. Het onder valse voorwaarden ronselen van werknemers die door wurgcontracten gedwongen zijn zich te schikken in arbeidsvoorwaarden die ver beneden de standaard liggen van wat in het land van tewerkstelling als acceptabel wordt beschouwd, wordt ingegeven door het economisch gewin 
dat daarmee valt te behalen. Dat pleit ervoor de grootte van het economisch gewin te verdisconteren in de definitie van "uitbuiten". Ook taalkundig gezien valt het accent op het gewin: uitbuiten veronderstelt dat de "uitbuiter" profiteert.' (46)

Ten slotte komt Knigge toe aan beantwoording van zijn derde vraag: spelen, en zo ja, in hoeverre, de instemming van het slachtoffer en de keuzemogelijkheden die hem zijn gelaten een rol bij de vraag of er sprake is van (oogmerk van) uitbuiting.

Knigge gaat in op een uit artikel 3, onderdelen a en b, van het Palermo Protocol voortvloeiende benadering waarbij (on)vrijwilligheid alleen een rol speelt bij de gedraging van de dader en de wil van het slachtoffer niet relevant is bij de vraag of deze gedraging geschiedde met het oogmerk van uitbuiting. Hij acht deze benadering moeilijk houdbaar. Bij gedwongen arbeid is onvrijwilligheid ingebakken. Het gebrek aan wilsvrijheid lijkt dus een kenmerk van uitbuiting te zijn. Daarin lijkt bovendien de reden voor strafbaarstelling te zijn gelegen. Knigge wijst er op dat onder de gelding van de artikelen 25oter en 250 (oud) Sr de onvrijwilligheid van het geëxploiteerd worden een element van de uitbuitingssituatie was. ${ }^{188} \mathrm{Hij}$ acht de ontkoppeling van de toegepaste dwang en de uitbuiting kunstmatig en soms zelfs niet mogelijk (49-52).

Knigge concludeert dat het oogmerk van de dader erop gericht moet zijn om het slachtoffer in een uitbuitingssituatie te brengen. Voldoende is dat het slachtoffer objectief gezien geen (vrije) keuze heeft. Als dat het geval is - en dat is dan de betekenis van het 'overbodige' artikel 3 (b) Palermo Protocol - doet de eventuele instemming van het slachtoffer niet meer ter zake. Van een vrije keuze kan dan immers geen sprake zijn (53). De maatstaf dat het bij uitbuiting gaat om een persoon 'die onder de gegeven omstandigheden redelijkerwijs geen andere keuze heeft', lijkt voor alle vormen van uitbuiting te gelden (54).

Er bestaan volgens Knigge grote verschillen in de mate van vrijheid die het slachtoffer van uitbuiting is gelaten. Dwangarbeid en slavernij gaan per definitie gepaard met een grote mate van onvrijheid. Die extreme vorm van onvrijheid is geen noodzakelijk element van alle vormen van uitbuiting. Dat is niet anders bij 'met slavernij en dienstbaarheid te vergelijken praktijken'. Of daarvan sprake is hangt af van allerlei factoren. De door de Nationaal Rapporteur Mensenhandel en het openbaar ministerie gehanteerde factoren en indicatoren die wijzen op uitbuiting of een uitbuitingssituatie, lijken zich te centreren rond twee polen:

'De eerste pool is die van afhankelijkheid van de tewerkgestelde en de mate van onvrijheid waarmee de tewerkstelling gepaard gaat. De tweede pool is die van de (slechte) arbeidsvoorwaarden en van het economisch gewin dat als gevolg daarvan door de werkgever wordt behaald. Men zou kunnen spreken van communicerende vaten: hoe groter de onvrijheid, hoe minder belangrijk het economisch gewin wordt. 
Als de werknemer tijdens het werk wordt vastgeketend en 's nachts wordt opgesloten (zodat de tewerkstelling de dwangarbeid nadert of daaraan gelijk is), is sprake van uitbuiting, ook als met het loon weinig mis zou zijn. Als daarentegen de werknemer wel bewegingsvrijheid wordt gelaten, zal de uitbuiting vooral gezocht moeten worden in de erbarmelijke arbeidsomstandigheden en het daardoor behaalde economisch gewin. Zoals eerder werd opgemerkt zijn de begrippen gedwongen arbeid, slavernij en dienstbaarheid geheel gedefinieerd in termen van macht, en onvrijheid (hiervoor, onder 48). De begrippen zijn dus éénpolig. Juist omdat het bij vergelijkbare praktijken wél om tweepolige uitbuitingsvormen gaat, uitbuitingsvormen dus waarbij ook andere factoren meewegen, is er geen reden om daarbij eenzelfde maatstaf van onvrijheid te eisen als waardoor gedwongen arbeid, slavernij en uitbuiting wordt gekenmerkt.'(56)

Het hof heeft kennelijk geoordeeld dat van oogmerk van uitbuiting geen sprake is, nu de door verdachte beoogde arbeidssituatie geen uitbuiting oplevert. De onjuiste rechtsopvatting van het hof ten aanzien van de onvrijwilligheid werkt volgens Knigge door in de opvatting van het hof over de uitbuiting (58 en 62).

Knigge concludeert dat het oordeel van het hof dat geen sprake is van (het oogmerk van) uitbuiting zweemt naar een onjuiste rechtsopvatting en in ieder geval, bezien in het licht van hetgeen het hof feitelijk heeft vastgesteld, niet zonder meer begrijpelijk is.

\section{De Hoge Raad}

De Hoge Raad begint met een uitvoerige weergave van de relevante wetsgeschiedenis inzake artikel 273 a (oud) $\mathrm{Sr}^{189}$ Vervolgens citeert de Hoge Raad uit de memorie van toelichting en de memorie van antwoord bij het wetsvoorstel dat heeft geleid tot artikel 25oter (oud) Sr, omdat de inhoud van deze bepaling is geïncorporeerd in artikel 273a (oud) en dus de wetsgeschiedenis en de rechtspraak daarover naar zijn oordeel niet hun belang hebben verloren. ${ }^{\mathrm{I}}{ }^{\circ}$ In de door de Hoge Raad geciteerde wetsgeschiedenis inzake artikel 250 a (oud) Sr staat centraal de in hoofdstuk 2.I.5 weergegeven uiteenzetting over het bestanddeel 'misbruik van uit feitelijke verhoudingen voortvloeiend overwicht' en over het begrip 'uitbuitingssituatie' dat gebruikt wordt ter verduidelijking van dit misbruik.

Vervolgens verwijst de Hoge Raad naar zijn arrest van 5 februari 2002, NJ 2002, 546 inzake artikel $250 t e r$ (oud) Sr, waarin eveneens de relevante wetsgeschiedenis was geciteerd. De Hoge Raad citeert uit dat arrest de volgende overwegingen:

'5.5. Uit deze wetsgeschiedenis moet worden afgeleid dat, indien zich een situatie voordoet - door de wetgever als uitbuitingssituatie aangeduid - waarin de prostitué(e) niet of slechts in verminderde mate de mogelijkheid heeft een vrije keuze te maken met betrekking tot het al dan niet aangaan of voortzetten van zijn of haar relatie met de exploitant - waarbij als een geval waarin een uitbuitingssituatie kan worden verondersteld onder meer wordt genoemd dat de prostitué(e) illegaal in Nederland

I89 Kamerstukken II 2003/04, 29 29I, nr. 3.

I9o Kamerstukken II I988/99, 2 I 027, nrs. 3 en 5. 
verblijft - degene die de betrokkene tot prostitutie heeft gebracht, niet een beroep erop kan doen dat zijn opzet niet erop gericht was dat de betrokkene zich heeft overgegeven aan prostitutie als gevolg van (het gebruik van) het overwicht dat uit de desbetreffende feitelijke verhoudingen voortvloeide.

5.6. Anderzijds zal, naar moet worden aangenomen, de dader zich wel bewust moeten zijn van de relevante feitelijke omstandigheden van de betrokkene waaruit het overwicht voortvloeit, dan wel verondersteld moet worden voort te vloeien, in die zin dat ten minste voorwaardelijk opzet ten aanzien van die omstandigheden bij de dader aanwezig moet zijn. Anders zouden de verdachte niet bekende en ook niet kenbare hoogstpersoonlijke omstandigheden van betrokkene relevant zijn. Anders dan in art. 25oter, eerste lid onder $3^{\circ}$, Sr, waarin het bestanddeel van de minderjarigheid geheel is geobjectiveerd, gaat de dader hier dus niet slechts vrijuit indien afwezigheid van alle schuld ten aanzien van zodanige omstandigheden moet worden aangenomen, doch zal het bovenbedoelde opzet uit de bewijsmiddelen moeten kunnen worden afgeleid.'

Ingevolge het arrest van 2002 volgt uit het illegale verblijf van het slachtoffer in Nederland dat een afhankelijke positie - een uitbuitingssituatie - mag worden verondersteld en dat niet van belang is of het juist die situatie is geweest die de poging van verdachte om de betrokkene tot prostitutie te brengen succesvol heeft doen zijn, en of de dader zich daarvan bewust is geweest. Evenmin is van belang dat wellicht ook andere, de verdachte niet bekende factoren aan die afhankelijkheid van de betrokkene hebben bijgedragen. ${ }^{191}$

Voor het bewijs van handelen door misbruik van overwicht of door misbruik van een kwetsbare positie van het slachtoffer is volgens de Hoge Raad toereikend dat bij de dader voorwaardelijk opzet aanwezig is ten aanzien van de feitelijke omstandigheden waaruit dat overwicht of die kwetsbare positie voortvloeit of verondersteld wordt voort te vloeien.

I9I De door de Hoge Raad aan zijn arrest van 2002 ontleende redenering komt kort gezegd op het volgende neer: wanneer het slachtoffer verkeert in een - objectief vast te stellen - uitbuitingssituatie, is voor het bewijs van 'misbruik' voldoende dat de dader zich bewust is geweest van de relevante feitelijke omstandigheden van het slachtoffer waaruit het 'overwicht' of de 'kwetsbare positie' voortvloeit of verondersteld moet worden voort te vloeien. De aanwezigheid van een afhankelijke positie is voldoende. Daarbij is niet van belang of (I) de dader het opzet had om met gebruik van zijn overwicht het slachtoffer in de prostitutie te brengen, (2) juist de uitbuitingssituatie de poging van de dader om het slachtoffer tot prostitutie te brengen heeft doen slagen, (3) de dader zich bewust is geweest van de eventuele gevolgen van deze situatie en (4) andere de dader onbekende factoren aan de afhankelijkheid van het slachtoffer hebben bijgedragen. Voor een goed begrip van deze redenering is enige kennis van de casuspositie in het arrest van 2002 behulpzaam. Ten laste was gelegd dat verdachte twee slachtoffers door misbruik van uit feitelijke verhoudingen voortvloeiend overwicht tot prostitutie had gebracht. De in verband met het misbruik genoemde omstandigheden hielden in dat de slachtoffers eerder slachtoffer van verkrachting waren geweest, schulden hadden en illegaal in Nederland verbleven. Verdachte had geen betrokkenheid bij en opzet op de eerste twee omstandigheden. Wel werd bewezen verklaard dat verdachte ten minste voorwaardelijk opzet had op de illegale status van de slachtoffers. Dat gegeven alleen is voldoende voor het bestaan van een uitbuitingssituatie. Niet van belang is het of het juist die omstandigheid of andere factoren zijn geweest die de poging van verdachte om het slachtoffer tot prostitutie te brengen succesvol heeft doen zijn. Vgl. de conclusie van AG Wortel bij HR I8 april 2000, NJ 2000, 443. 
Dat volgt de vertaalslag naar de zaak zelf. Het hof heeft naar het oordeel van de Hoge Raad een te strenge eis gesteld door aan het bewijs van het eerste opzetvereiste de voorwaarde te verbinden dat 'doelbewust misbruik' is gemaakt van een kwetsbare positie. Dat is een onjuiste rechtsopvatting. Dat geldt evenzeer voor zover het hof voor het bewijs van het misbruik een verdergaand initiatief en actief handelen van de verdachte heeft vereist dan tot uitdrukking komt in de in de wet genoemde handelingen (werft enz.). Het is volgens de Hoge Raad geen zelfstandig vereiste dat het initiatief van verdachte is uitgegaan en dat het slachtoffer door de verdachte in een uitbuitingssituatie - dat is de situatie die de gelegenheid tot uitbuiting schept - is gebracht. De omstandigheid dat slachtoffers tevoren op andere plaatsen hebben gewerkt, hoeft geen aanwijzing te zijn voor vrijwilligheid en het ontbreken van een uitbuitingssituatie.

Wat betreft de motivering over het ontbreken van (het oogmerk van) uitbuiting overweegt de Hoge Raad:

\begin{abstract}
'De vraag of - en zo ja, wanneer - sprake is van "uitbuiting" in de zin van de onderhavige bepaling (artikel 273a (oud) Sr) is niet in algemene termen te beantwoorden, maar is sterk verweven met de omstandigheden van het geval. Bij de beantwoording van die vraag komt in een geval als het onderhavige onder meer betekenis toe aan de aard en duur van de tewerkstelling, de beperkingen die zij voor de betrokkene meebrengt, en het economisch voordeel dat daarmee door de tewerksteller wordt behaald. Bij de weging van deze en andere relevante factoren dienen de in de Nederlandse samenleving geldende maatstaven als referentiekader te worden gehanteerd. Daar komt bij dat voor de vervulling van de delictsomschrijving niet nodig is dat het slachtoffer daadwerkelijk wordt uitgebuit.'
\end{abstract}

'In het licht van de niet onbegrijpelijke vaststelling van het hof dat de slachtoffers zich in een kwetsbare positie bevonden omdat zij illegaal in Nederland verbleven (verg. HR I8 april 2000, LJN ZDi788, NJ 2000, 443, NbSr 2000, I40) en zij zich dus in een uitbuitingssituatie bevonden, is het kennelijke oordeel van het hof dat van (het oogmerk van) uitbuiting in de zin van artikel 273a (oud) Sr geen sprake was, zonder nadere motivering, die ontbreekt, niet begrijpelijk, gelet op de vaststellingen van het hof dat sommige van de in het restaurant van verdachte werkzame slachtoffers enkel in ruil voor kost en inwoning en anderen voor een maandinkomen van tussen $€ 450$ en $€ 800$ werkdagen van II en I3 uur maakten, dat zij niet meer dan vijf vrije dagen per maand hadden, en zij hun slaapkamer met verschillende anderen moesten delen.'

\title{
4.3.3 Balans
}

$\mathrm{Na}$ bespreking van de conclusie van advocaat-generaal Knigge en het arrest van de Hoge Raad is het tijd voor het opmaken van de balans.

Bij de beoordeling of er sprake is van mensenhandel wordt gekeken naar vier met elkaar samenhangende elementen: (I) het handelen van de dader (met gebruik van 
ongeoorloofde middelen een handeling ten opzichte van het slachtoffer verrichten met het oog op diens uitbuiting - mensenhandel in eigenlijke zin - dan wel met gebruik van die middelen het slachtoffer brengen tot of houden in het zich beschikbaar stellen tot het verrichten van arbeid of diensten - het eigenlijke uitbuiten), (2) de (kwetsbare) situatie waarin het slachtoffer verkeert (uitbuitingssituatie), (3) de aard van de door het slachtoffer te verrichten arbeid of diensten en (4) de omstandigheden waaronder die (zullen) worden verricht. De elementen 3 en 4 kunnen nadere inhoud aan de uitbuitingssituatie geven. Soms wordt het gebruik van specifieke ongeoorloofde middelen (misbruik van overwicht of van een zwakke positie) verondersteld in een uitbuitingssituatie.

Onvrijwilligheid en arbeid tezamen (in een uitbuitingssituatie) vormen uitbuiting.

Bij de behandeling van een mensenhandelzaak moeten de verschillende ingrediënten worden ontleed op hun relevantie. Dat is van belang voor een goede beoordeling van de zaak en voor beantwoording van de vraag of het in een concrete zaak relevante feitencomplex onder de delictsomschrijving van artikel $273 \mathrm{f} \mathrm{Sr}$ kan worden gebracht. ${ }^{192}$ De bestanddelen in de delictsomschrijving en de werkelijkheid moeten met elkaar matchen. Maar daarbij moeten de verschillende ingrediënten ook in onderling verband en het feitencomplex ook in zijn geheel worden bezien, omdat de ingrediënten van mensenhandel met elkaar samenhangen en in elkaar grijpen. ${ }^{193}$ Ontleding en holistische benadering gaan hand in hand.

De wetgever heeft veel overgelaten aan de rechtspraktijk om artikel $273 \mathrm{f}$ Sr toe te snijden op de harde realiteit van de moderne slavernij. De rechtspraktijk moest op een gedwongen zoektocht. ${ }^{194} \mathrm{Na}$ enige jaren van verkenning en worsteling heeft de Hoge Raad nu voor de nodige klaarheid gezorgd.

In de uitspraak van de Hoge Raad en de conclusie van de advocaat-generaal Knigge zijn vele relevante elementen en struikelpunten aan de orde gekomen en tegen het licht gehouden en verhelderd. Het hof, de Hoge Raad en Knigge hebben hun oordeel en conclusie deels gegrond op de wetsgeschiedenis die uitvoerig in hoofdstuk 2 is besproken. De wetsgeschiedenis is geanalyseerd en van kanttekeningen voorzien. Artikel $273 \mathrm{f} \mathrm{Sr}$ is waar nodig gefileerd.

Deze zaak is instructief en illustratief. Hij legt de dilemma's en afwegingsmechanismen bloot waarmee de strafrechter te maken krijgt, en die kunnen leiden tot verschillende uitkomsten. De zaak geeft een fraai voorbeeld van rechtsvinding op basis van wetshistorische, tekstuele en teleologische interpretatie.

De uitspraak van de Hoge Raad tezamen met de conclusie van Knigge heeft de strekking en de betekenis van artikel $273 \mathrm{f} \mathrm{Sr}$ aanzienlijk verduidelijkt. Artikel $273 \mathrm{f}$ Sr beoogt een brede bescherming te bieden aan slachtoffers van mensenhandel. Dat

I92 NRM 7, p. 539.

I93 Zie het explanatory report bij het Raad van Europa Verdrag, par. 75, 76 en 9o. Wordt bijvoorbeeld in een geval van gedwongen arbeid de instemming van het slachtoffer tegengeworpen, dan moet de deugdelijkheid van dit verweer worden bezien in het licht van alle omstandigheden van de zaak.

I94 NRM 7, p. 532 e.v. 
past in de visie van de Hoge Raad op strafwetgeving die personen beoogt te beschermen tegen aantasting van hun lichamelijke en geestelijke integriteit. Uitspraak en conclusie laten zien dat artikel $273 \mathrm{f}$ Sr voorziet in een dergelijke ruime bescherming. Het is belangrijk om dat vast te stellen en vast te houden. Uit de uitspraak volgt dat de rechtspraak tot nu toe te terughoudend is geweest. ${ }^{195}$ De Hoge Raad heeft de weg vrij gemaakt voor een effectieve strafrechtelijke bescherming van slachtoffers van mensenhandel. De uitspraak van de Hoge Raad heeft inmiddels haar weg gevonden naar de rechtspraak. ${ }^{196}$

De toepassing van artikel 273 f Sr leden I en 2 - vaststelling van de relevante feiten en de waardering daarvan in het licht van de delictsomschrijving - zal evenwel lastig blijven.

\section{$5 \quad$ Overige strafrechtelijke aspecten van mensenhandel}

\section{I Rechtsmacht en dubbele strafbaarheid}

De rechtsmacht inzake mensenhandel is ruim. Ruime toepasselijkheid van de Nederlandse strafwetgeving inzake mensenhandel strekt tot een brede bescherming van slachtoffers. Deze rechtsmacht is onlangs nog verruimd door de inwerkingtreding van wetgeving die onder meer uitvoering heeft gegeven aan het Verdrag van de Raad van Europa ter bestrijding van mensenhandel. ${ }^{197}$

Het is vermeldenswaard dat elk nieuw internationaal instrument inzake de bestrijding van mensenhandel voorziet in weer een ruimere rechtsmacht dan is voorzien in het instrument dat daarvóór tot stand is gebracht. Zo gaat de ontwerprichtlijn verder dan voornoemd verdrag. ${ }^{198}$ Een van de verkoopargumenten voor de totstand-

I95 Het is niet uitgesloten dat enige zaken waarin een vrijspraak volgde, in het licht van de uitspraak van de Hoge Raad tot een veroordeling zouden hebben geleid. Vgl. Rechtbank Den Haag 2I november 2006, LJN: AZ2707 (Hennepknippers), Rechtbank Den Haag 5 oktober 2007, LJN: BB5303 (Poolse schoonmaaksters), Rechtbank Zwolle 29 april 2008, LJN: BDo846 (Illegale Indiërs), Rechtbank Rotterdam 3 december 2008, niet gepubliceerd (Marokkaanse bruid).

I96 Rechtbank Den Haag 3 mei 20I0, LJN: BM3374 en 12 mei 20I0, LJN: BM4240 en Rechtbank Leeuwarden 13 juli 20I0, LJN: BNI233.

I97 Wet van 26 november 2009, Stb. 525. Inwerkingtreding I april 20Io. Het Verdrag van de Raad van Europa verplicht tot strafbaarstelling van mensenhandel en een aantal mensenhandel faciliterende misdrijven met betrekking tot reis- en identiteitsdocumenten. Artikel 3I lid I verplicht tot rechtsmacht over mensenhandel, indien het feit is gepleegd op het eigen grondgebied (onderdelen a-c), door een onderdaan of door een statenloze persoon die een vaste woon- of verblijfplaats heeft, indien het misdrijf ook strafbaar is volgens het recht van de plaats delict of is gepleegd buiten de rechtsmacht van enige staat (onderdeel d), of tegen een onderdaan (onderdeel e). Nederland heeft geen gebruik gemaakt van de in artikel 3 I lid 2 geboden mogelijkheid om de regeling in de onderdelen d en e niet of gedeeltelijk toe te passen.

I98 Zie artikel I5 UNTOC Verdrag voor het Palermo Protocol, artikel 6 EU kaderbesluit, artikel 3I Raad van Europa Verdrag en artikel 8 ontwerp richtlijn. De regeling in de ontwerp richtlijn ziet er als volgt uit. Uitgangspunt in artikel 8 lid I is verplichte rechtsmacht voor (a) een feit, gepleegd op het eigen grondgebied c.a., (b) door een onderdaan of een persoon die op het eigen grondgebied zijn vaste woon- of verblijfplaats heeft, (c) een feit, gepleegd tegen een onderdaan of een persoon die op het eigen grondgebied zijn vaste woon- of verblijfplaats heeft en (d) een 
koming van een nieuw rechtsinstrument naast de al bestaande rechtsinstrumenten is het extra dat het nieuwe rechtsinstrument te bieden heeft (de zogenoemde 'added value'). Zo wedijveren de organisaties onder wier hoede deze instrumenten tot stand komen met elkaar in elkaar overtreffende fermheid. ${ }^{199}$

De regeling van extraterritoriale rechtsmacht is ingewikkeld en verbrokkeld, als gevolg van uitvoering van opeenvolgende internationale instrumenten Dat is niet anders voor de regels inzake de jurisdictie inzake mensenhandel. Hiervoor zijn de artikelen 5 en 5 a Sr relevant. Artikel $5 \mathrm{Sr}$ gaat over rechtsmacht voor Nederlanders en artikel 5a Sr over rechtsmacht voor vreemdelingen met een vaste woon- of verblijfplaats in Nederland. Dat geldt ook voor rechtspersonen. ${ }^{200}$

De Nederlandse strafwet is in de regel van toepassing op de Nederlander die buiten Nederland misdrijven pleegt. Daarbij is volgens artikel 5 lid I, onderdeel $2^{\circ}$, Sr het vereiste van dubbele strafbaarheid uitgangspunt. ${ }^{201}$ Maar volgens onderdeel $3^{\circ}$ geldt dit vereiste niet voor mensenhandel tegen personen onder 18 jaar. ${ }^{202}$ In onderdeel $5^{\circ}$ wordt ter uitvoering van het Verdrag van de Raad van Europa ter bestrijding van mensenhandel specifieke rechtsmacht gevestigd voor mensenhandel tegen personen vanaf I8 jaar en voor een aantal met reis- en identiteitsdocumenten samenhangende delicten, voor zover gepleegd buiten de rechtsmacht van enige staat. Overigens geldt voor mensenhandel en deze samenhangende delicten de hoofdregel van rechtsmacht met het vereiste van dubbele strafbaarheid.

De Nederlandse strafwet is in de regel - zie echter artikel $4 \mathrm{Sr}$ - niet toepasselijk op de vreemdeling die buiten Nederland strafbare feiten pleegt. Artikel 5a Sr maakt daarop een uitzondering en vestigt rechtsmacht voor vreemdelingen met een vaste woon- of verblijfplaats die zich buiten Nederland schuldig maken aan een aantal specifieke misdrijven, waaronder mensenhandel. Wat mensenhandel en de

feit, gepleegd ten behoeve van een rechtspersoon die is gevestigd in het eigen grondgebied. Lidstaten krijgen in lid 2 de bevoegdheid om deze jurisdictieregels niet dan wel alleen in specifieke gevallen of omstandigheden toe te passen voor zover een feit buiten het eigen grondgebied is gepleegd door een persoon met een vaste woon- of verblijfplaats, of het feit is gepleegd tegen een persoon of ten behoeve een rechtspersoon. Bij rechtsmacht voor feiten gepleegd door eigen onderdanen of - voor zover van toepassing - personen met een vaste woon- of verblijfplaats mag volgens lid 3 geen beroep worden gedaan op het ontbreken van dubbele strafbaarheid.

I99 Kritiek op de wedloop tussen de Raad van Europa en de Europese Unie komt van de Eerste Kamer. Zie de brief van de voorzitter van de vaste commissie voor de JBZ-Raad van 3 november 2009 aan de minister van Justitie (kenmerk I45089.orU).

200 Uit de jurisprudentie van de Hoge Raad kan worden afgeleid dat een Nederlandse rechtspersoon als een 'Nederlander' in de zin van artikel 5 Sr wordt aangemerkt (vgl. Hoge Raad I8 oktober I988, NJ I989, 496). Op dezelfde wijze zal, bij toepassing van artikel 5a, een in Nederland gevestigde buitenlandse rechtspersoon als 'ingezetene' kunnen worden aangemerkt. Indien deze rechtspersoon een strafbaar feit pleegt, bestaat derhalve rechtsmacht, ongeacht de vraag of de rechtspersoon voordeel heeft genoten.

20I Zie hierover in algemene zin de notitie 'dubbele strafbaarheid in het Nederlandse strafrecht, Kamerstukken II 2003/04, 29 45I, nr. I en verslag van een schriftelijke overleg, nr. 2. Deze notitie gaat in op het vereiste van dubbele strafbaarheid bij Europese strafrechtelijke samenwerking en bij rechtsmacht.

202 Onderdeel $3^{\circ}$ omvat daarnaast zedendelicten en genitale verminking ten aanzien van vrouwen onder I8 jaar. Aan dit onderdeel ligt het amendement-Barth bij het voorstel van wet partiële herziening zedelijkheidswetgeving ten grondslag, Kamerstukken ll 2001/02, 27 745, nr. 7 . 
aanverwante misdrijven betreft, komt de regeling overeen met de regeling ten aanzien van Nederlanders.

Door de omstandigheid dat de strafrechter de in de Nederlandse samenleving geldende maatstaven hanteert voor de beoordeling of er sprake is van uitbuiting ${ }^{203}$ en door het loslaten van het vereiste van dubbele strafbaarheid wordt de Nederlandse maatstaf geëxporteerd naar activiteiten die in het land waar zij zijn verricht, als aanvaardbare uitbating worden aangemerkt of in ieder geval niet strafwaardig worden geacht. Voor Nederland is alleen ondernemerschap aanvaardbaar dat naar Nederlandse maatstaven verantwoord wordt geacht. ${ }^{204}$ Bij hantering van de Nederlandse maatstaf wordt natuurlijk wel rekening gehouden met de in het betrokken land gebruikelijke arbeidsomstandigheden en -voorwaarden. Die moeten in het licht van de Nederlandse maatstaf nog verantwoord zijn. Gevaarlijke of ongezonde kinderarbeid in Nederland is ook gevaarlijk of ongezond in het betrokken land. Maar de hoogte van het Nederlandse minimumloon is natuurlijk niet maatgevend voor een billijke beloning elders.

Nederlanders en vreemdelingen met een vaste woon- of verblijfplaats in Nederland doen er goed aan om bij het doen van 'zaken' in den vreemde rekening te houden met de Nederlandse maatstaf.

Er is recentelijk onderzoek gedaan naar vormgeving en inhoud van de regeling van extraterritoriale rechtsmacht in Nederland. Daarbij is onder meer aandacht geschonken aan het vereiste van dubbele strafbaarheid, het onderscheid tussen Nederlanders en vreemdelingen die in Nederland een vaste woon- of verblijfplaats hebben en het passieve personaliteitsbeginsel. De uitkomsten van dit onderzoek zullen worden betrokken bij een eventuele algemene herziening van de regeling inzake jurisdictie. ${ }^{205}$

Het vereiste van dubbele strafbaarheid speelt ook een rol bij de strafrechtelijke samenwerking. Soms is voor die samenwerking nodig dat het desbetreffende feit ook strafbaar is in het land waarvan medewerking wordt verzocht. Binnen de EU wordt de toepasselijkheid van het vereiste teruggedrongen. In dat verband verdient vermelding dat mensenhandel behoort tot de zogenoemde lijstfeiten in instrumenten inzake wederzijdse erkenning van rechterlijke beslissingen binnen de Europese Unie. In mensenhandelzaken kan de lidstaat die is aangezocht om een bevel uit te voeren dat is uitgevaardigd in een andere lidstaat, aan die staat niet tegenwerpen dat de vorm van mensenhandel die aan het bevel ten grondslag ligt, naar zijn recht niet strafbaar is. Beslissend is in zo'n geval of het desbetreffende feit strafbaar is gesteld in de wetgeving van de uitvaardigende staat. Voor de samenwerking

203 Zie daarvoor HR 27 oktober 2009, LJN: BI7099, besproken in hoofdstuk 4.3.2.

204 Zie over de strafrechtelijke aansprakelijkheid voor (extraterritoriale) schendingen van normen van maatschappelijk verantwoord ondernemen, waaronder ook mensenhandel kan worden begrepen, F.G.H. Kristen, Maatschappelijk verantwoord ondernemen en strafrecht (preadvies Nederlandse Juristen-Vereniging), Kluwer, Deventer 2010.

205 Kamerstukken II 2007/08, 3I 39I, nr. 3, p. 9. 
in mensenhandelzaken in de Europese Unie is dus niet nodig dat de lidstaten op dezelfde wijze uitvoering geven aan de uit EU-instrumenten (nu kaderbesluit, straks richtlijn) voortvloeiende verplichting tot strafbaarstelling van mensenhandel.

\section{$5.2 \quad$ Verjaring}

Het verjaringsregime inzake mensenhandel strekt ter bescherming van het slachtoffer. Voor verjaring voor mensenhandel gelden ingevolge artikel 70 lid I, onderdelen $I^{\circ}$ en $2^{\circ}$, Sr verjaringstermijnen van 12 jaar (gronddelict) en 20 jaar (onder strafverzwarende omstandigheden). Voor daders onder 18 jaar geldt de hoofdregel dat de gewone verjaringstermijn tot de helft wordt ingekort. Deze regel geldt niet voor daders van I6 en I7 jaar ten aanzien van een slachtoffer onder I8 jaar (artikel 77d Sr).

De verjaring gaat volgens de hoofdregel van artikel 7I aanhef Sr in daags na het plegen van het feit. Bij zedenmisdrijven en mensenhandel ten aanzien van personen onder I8 jaar gaan de verjaringstermijnen lopen vanaf het moment waarop de persoon 18 is geworden. Dit geeft jeugdige slachtoffers meer tijd om op een 'mondige' leeftijd te beslissen om aangifte te doen.

In de politiek klinkt de roep luider om de verjaring in zeer ernstige zaken zoals zware zedenmisdrijven gepleegd tegen kinderen af te schaffen, zoals nu al het geval is bij misdrijven waarop levenslang staat. Aan die wens zal gehoor worden gegeven. Zo heeft de regering naar aanleiding van de berichtgeving over seksueel misbruik in kerkelijke instellingen een wetsvoorstel aangekondigd dat strekt tot opheffing van de verjaringstermijn bij ernstige zedenmisdrijven gepleegd tegen minderjarige slachtoffers. ${ }^{206}$

\subsection{Strafbaarstelling van de klant van een slachtoffer van mensenhandel}

Artikel I9 van het Verdrag van de Raad van Europa ter bestrijding van mensenhandel en artikel ${ }_{5}$ lid 4 van de ontwerprichtlijn geven partijen respectievelijk lidstaten in overweging om strafrechtelijk op te treden tegen klanten die bewust gebruik maken van de diensten van een slachtoffer van mensenhandel. Het betreft een aansporing, geen verplichting. De instrumenten laten ruimte om op nationaal niveau een eigen invulling aan de bepaling te geven. Niettemin is er ontegenzeggelijk sprake van een ontwikkeling naar het strafrechtelijk aanspreken van de vraagkant op diens verantwoordelijkheid bij de bestrijding van mensenhandel. In hoofdstuk 3 hebben we gezien dat klant en uitbuiter onder omstandigheden in een en dezelfde persoon kunnen samenvallen. In dat geval kan tegen de 'klant' worden opgetreden op grond van artikel $273 \mathrm{f} \mathrm{Sr}$. Bij uitbuiting in de seksindustrie wordt het slachtoffer door de uitbuiter gedwongen tot het verlenen van seksuele diensten aan de klant. Deze klant van seksuele dienstverlening van een slachtoffer van mensenhandel valt in beginsel

206 Zie Kamerstukken II 2009/IO, 32 I23 VI, nr. 8I. 
buiten de reikwijdte van artikel $273 \mathrm{f}$ Sr. Vanuit het oogpunt van handhaving zouden er nogal wat zwarigheden aan een dergelijke strafbaarstelling kleven. Het bewijs dat een klant opzettelijk gebruik heeft gemaakt van de diensten van een slachtoffer van mensenhandel is immers moeilijk te leveren.

Opgemerkt zij dat tegen de klant van een minderjarige prostituee strafrechtelijk kan worden opgetreden op grond van artikel 248b Sr respectievelijk de artikelen 244 en 245 Sr. In hoofdstuk 2 hebben we gezien dat de in artikel $248 \mathrm{~b}$ Sr opgenomen strafbaarstelling van de klant van een prostituee van $\mathrm{I} 6$ of 17 jaar, bij amendement in het Wetboek van Strafrecht is geïntroduceerd. ${ }^{207}$ Inmiddels verplichten ook internationale rechtsinstrumenten tot strafbaarstelling van de klant van een prostituee beneden de leeftijd van 18 jaar. ${ }^{208}$

In het wetsvoorstel Regulering prostitutie en bestrijding misstanden seksbranche wordt voorgesteld de klant van illegaal aanbod van prostitutie strafbaar te stellen (zie nader par. 6.2). Volgens de toelichting op dit voorstel wordt met deze strafbaarstelling door Nederland op eigen wijze invulling gegeven aan artikel ig van het Verdrag van de Raad van Europa. De prostituant zal zich aan de hand van het registratiebewijs of de vergunning ervan moeten vergewissen of sprake is van legale of illegale prostitutie. Het strafrechtelijke risico dat sprake is van illegale prostitutie komt voor rekening van de prostituant. ${ }^{209}$ De voorgestelde strafbaarstelling kan indirect bijdragen aan de aanpak van mensenhandel. Volgens de memorie van toelichting is de veronderstelling gerechtvaardigd dat door de verscherpte regulering waaraan legale vormen van prostitutie door het wetsvoorstel zullen worden onderworpen, eventuele slachtoffers van uitbuiting in de prostitutie zich vooral in het illegale deel van de branche zullen ophouden. ${ }^{210}$

\section{Aanpalende wet- en regelgeving}

\section{I Inleiding}

In dit hoofdstuk zullen we kort en globaal ingaan op regelgeving of voorstellen daartoe die voorzien in een indirecte aanpak van mensenhandel. Het betreft de voorgestelde nieuwe prostitutiewetgeving en (ordenings)wetgeving die condities schept voor (I) arbeid of dienstverlening die verantwoord is, tegen een behoorlijke honorering en onder behoorlijke arbeidsomstandigheden door personen die hier

207 Amendement-Barth, Kamerstukken II I998/99, 25 437, nr. 9. Zie noot 9I.

208 Zie bijvoorbeeld artikel Ig lid I onder c van het Verdrag van de Raad van Europa inzake de bescherming van kinderen tegen seksuele uitbuiting en seksueel misbruik (Verdrag van Lanzarote) (Trb. 2008, 58).

209 Vgl. de in de wetsgeschiedenis gegeven uitleg ten aanzien van de strafrechtelijke aansprakelijkheid van de prostituant op grond van artikel 248b Sr (Kamerstukken I, 25 437, nr. I89e).

2IO Kamerstukken II 2009/IO, 32 2II, nr. 3, p. 35-36; zie ook Kamerstukken II 2009/IO, 32 2II, nr. 8, p. 57 en 58 . 
mogen zijn en werken en die fatsoenlijk gehuisvest zijn, of voor (2) medisch aanvaardbare orgaanverwijdering.

\subsection{Wetsvoorstel Regulering prostitutie en bestrijding misstanden seksbranche (32 21I)}

In hoofdstuk 2.I hebben we gezien dat het voorstel tot opheffing van het bordeelverbod er vooral op was gericht om gemeenten de mogelijkheid te geven ten aanzien van de exploitatie van prostitutie een vergunningenbeleid te voeren. Een vergunningenstelsel zou leiden tot een betere bescherming van de prostituee. Met de in vergunningen gestelde voorwaarden zou een objectieve normering van de arbeidsomstandigheden voor de prostituee kunnen worden bewerkstelligd. Exploitanten zouden aan die normen moeten voldoen om van een aanvaardbare vorm van exploitatie van prostitutie te kunnen spreken. In de wetsgeschiedenis wordt gesproken van een uitbuitingssituatie wanneer niet aan de vergunningvoorwaarden wordt voldaan. De exploitant die een uitbuitingssituatie schept, maakt volgens de wetgever misbruik van uit feitelijke verhoudingen voortvloeiend overwicht. ${ }^{211}$ De vraag wat de aan een vergunning voor de exploitatie van prostitutie verbonden voorschriften zouden moeten behelzen en of daarin uniformiteit zou moeten worden aangebracht, bleef bij de behandeling van het hiervoor vermelde wetsvoorstel I8 202 vrijwel onbesproken.

Tijdens de parlementaire behandeling van het hiervoor behandelde wetsvoorstel 25 437, dat ten grondslag lag aan de Wet opheffing algemeen bordeelverbod is de vraag aan de orde geweest of niet bij wet zou moeten worden voorzien in een nadere uniforme regulering van de exploitatie van prostitutie. Het tot stand brengen van bestuurlijke kaderwetgeving werd door de toenmalige ministers van Justitie Sorgdrager en Korthals evenwel afgehouden. Het voornaamste argument voor die terughoudendheid was gelegen in het feit dat de tijd voor specifieke prostitutiewetgeving nog niet rijp werd geacht: na opheffing van het bordeelverbod zou eerst de nodige ervaring moeten worden opgedaan met de gemeentelijke praktijk van vergunningverlening, alvorens eventuele aanvullende bestuurlijke wetgeving op het terrein van de prostitutie zou kunnen worden bepaald. ${ }^{212}$ Daarbij werd gewezen op de voorgenomen evaluaties van de wetgeving inzake de afschaffing van het bordeelverbod. Wel werd bij amendement voorzien in de bepaling die heeft geleid tot het huidige artikel I5Ia Gemeentewet. Dat artikel geeft gemeenten uitdrukkelijk de bevoegdheid om bij verordening voorschriften vast te stellen met betrekking tot het bedrijfsmatig geven van gelegenheid tot het verrichten van seksuele handelingen met of voor een derde tegen betaling. ${ }^{213}$

2II Kamerstukken II I990/9I, 2I 027, nr. 8, p. I.

2 I2 Kamerstukken II I997/98, 25 437, nr. 5, p. I7; Handelingen II, 28 januari I999, 45-3I08-3Io9.

2I3 Kamerstukken II I998/99, 25 437, nr. I8. 
Uit de evaluaties van de opheffing van het bordeelverbod en enkele andere onderzoeken is gebleken dat zowel in het legale als het illegale deel van de prostitutiebranche misstanden, zoals mensenhandel, nog steeds voortbestaan. ${ }^{214}$ Als belangrijkste oorzaak daarvan wordt het gebrek aan uniformiteit in gemeentelijk vergunningenbeleid genoemd. Volgens het coalitieakkoord tussen de Tweede Kamerfracties van CDA, PvdA en ChristenUnie (2007) is

'de prostitutiebranche (...) nog steeds - ondanks de legalisering - een "broeinest" van zwartwerken, vrouwenhandel, witwassen en andere vormen van illegaliteit en criminaliteit'.

Het coalitieakkoord heeft geleid tot het bij koninklijke boodschap van Io november 2009 ingediende wetsvoorstel Regulering prostitutie en bestrijding misstanden seksbranche. ${ }^{215}$ Voornoemd wetsvoorstel is op het moment van schrijven van dit preadvies aanhangig bij de Tweede Kamer. Het wetsvoorstel voorziet in de kaderwetgeving die door sommigen bij de opheffing van het bordeelverbod al werd bepleit. In hoofdlijnen houdt het wetsvoorstel het volgende in. De kern is dat alle vormen van prostitutie onder een vorm van regulering worden gebracht. Daartoe wordt voorzien in de invoering van een verplicht en uniform vergunningenstelsel voor de uitoefening van een seksbedrijf, daaronder begrepen de exploitatie van een prostitutiebedrijf. ${ }^{216}$ Samen met een registratieplicht voor prostituees en een landelijk register van vergunningen voor escortbedrijven wordt een zo veel mogelijk sluitend bestuurlijk stelsel in het leven geroepen dat mede de bestrijding van mensenhandel beter moet kunnen ondersteunen. De exploitatie van een seksbedrijf zonder vergunning en overtreding van enkele andere aan de exploitant gestelde normen worden als economisch delict strafbaar gesteld in de Wet economische delicten. ${ }^{217}$ Een van die normen betreft bijvoorbeeld adverteren. Dat is alleen toegestaan met vermelding van het vergunningnummer en een vast telefoonnummer. In het beoogde robuuste kader voor de aanpak van misstanden wordt ook de prostituee niet ontzien: wie zich niet-geregistreerd prostitueert, maakt zich schuldig aan een strafrechtelijk gesanctioneerde overtreding. Voor de prostituee geldt voorts de verplichting om bij het adverteren het registratienummer te vermelden. Voorts heeft de door het wetsvoorstel getrokken scheidslijn tussen legale en illegale prostitutie de weg vrijgemaakt voor strafbaarstelling van de klant van illegaal aanbod van prostitutie als sluitstuk van de voorgestelde regulering (zie nader hoofdstuk 5.3). Hier verdient voorts vermelding dat bij nota van wijziging is voorgesteld de leeftijdsgrens

2 I4 Zie Prostitutie in Nederland na opheffing van het bordeelverbod, WODC 2007.

215 Kamerstukken II 2009/IO, 32 2II, nrs. I-3.

2I6 Op grond van (het bij nota van wijziging gewijzigde) artikel I4 lid I, onder g, van het wetsvoorstel dient een vergunning voor exploitatie - onder andere - te worden geweigerd indien: 'er aanwijzingen zijn dat voor het seksbedrijf personen tewerkgesteld zijn of zullen zijn die, indien het prostituees betreft, nog niet de leeftijd van 2I jaar hebben bereikt, indien het overige personen betreft, nog niet de leeftijd van I8 jaar hebben bereikt, slachtoffer zijn van mensenhandel of verblijven of werken in strijd met het bepaalde bij of krachtens de Vreemdelingenwet 2000.'

2 I7 Artikel 32 wetsvoorstel. 
voor prostitutie te verhogen van I8 naar 2I jaar. ${ }^{218}$ Deze leeftijdsverhoging wordt primair bestuurlijk benaderd: de leeftijd waarop de - op grond van het wetsvoorstel voor prostitutie vereiste registratie kan plaatsvinden, wordt gesteld op 2I jaar. De in het Wetboek van Strafrecht op prostitutie betrekking hebbende bepalingen (o.a. de artikelen $248 \mathrm{~b}$ en $273 \mathrm{f} \mathrm{Sr}$ ) blijven bij deze benadering ongewijzigd. ${ }^{219}$ De voorgestelde leeftijdsverhoging heeft tot gevolg dat uitbating van een prostituee in de leeftijd van 18 tot 2I jaar als ongeoorloofde vorm van uitbating op grond van de Wet economische delicten strafbaar wordt. ${ }^{220}$ Uitbating van een prostituee beneden de leeftijd van I8 jaar blijft onverminderd als mensenhandel strafbaar. De leeftijdsverhoging heeft ook gevolgen voor de vraagzijde. De klant van een prostituee in de leeftijd van 18 tot 2I jaar, dat is per definitie een niet-geregistreerde prostituee, maakt zich schuldig aan een overtreding. ${ }^{221}$ Bij de klant van een prostituee die de leeftijd van $\mathrm{I} 8$ jaar nog niet heeft bereikt ligt evenwel vervolging op grond van artikel 248b Sr respectievelijk de artikelen 244 en 245 Sr voor de hand.

Bij de beoordeling van het Nederlandse beleid inzake prostitutie en mensenhandel wordt (vanuit het buitenland) wel de stelling verdedigd dat legalisering van de seksbranche meer prostitutie en daardoor meer mensenhandel aantrekt. Een verbod van uitbating van prostitutie zou het aanbod van en de vraag naar prostitutie doen verminderen. Het is moeilijk deze stelling met harde cijfers te staven of te ontkrachten. Om drie redenen. In de eerste plaats ontbreken harde cijfers. In de tweede plaats is er geen nulmeting. In de derde plaats is het ondoenlijk om fluctuaties in de (internationale) seksindustrie, waaronder een toename of afname van mensenhandel, toe te schrijven aan één factor, legalisering. Globalisering, internationalisering van de seksindustrie, mobiliteit, moderne communicatiemiddelen en nieuwe vormen van seksuele dienstverlening zijn autonome factoren die de omvang van de seksindustrie sterk beïnvloeden, los van de juridische context.

In het algemeen neemt men aan dat uitbuiting in een verbodssituatie beter gedijt dan in een legale situatie. ${ }^{222}$ Een prostituee is in een legale setting beter af dan in de criminaliteit.

2 I8 Kamerstukken II 2009/Io, 32 2II, nr. 9. Vgl. het gewijzigd amendement-Agema dat inhoudelijk aansluit bij de nota van wijziging, Kamerstukken II 2009/IO, 32 2II, nr. 7. Zie voor een toelichting op de beleidsmatige overwegingen waarop dit voorstel berust Kamerstukken II 2009/IO, 32 2II, nr. 8, p. 29-32.

2 I9 Vgl. het initiatiefwetsvoorstel van het lid Agema tot wijziging van het Wetboek van Strafrecht tot verhoging van de minimumleeftijd voor prostituees naar 2I jaar, waarin wordt voorgesteld onder andere de artikelen $248 \mathrm{~b}$ en $273 \mathrm{fSr}$ te wijzigen (Kamerstukken II 2008/09, 3 I 983, nrs. I-3).

220 Artikel 22 jo. 32 wetsvoorstel 32 2II.

22I Artikel 29 wetsvoorstel 32 2II.

222 Deze zienswijze lijkt steun te vinden in het recent gepubliceerde rechtsvergelijkende onderzoek 'Legislation and the situation concerning trafficking in human beings for the purposes of sexual exploitation in the EU Member States' van het International Centre for Migration Policy Development, waarin wordt geconcludeerd dat: 'In the context of addressing trafficking in human beings, the benefits of legalisation of prostitution have factors that outweigh the benefits of criminalisation of prostitution as such or of demand' (p. I30 rapport, raadpleegbaar via www.icmpd.org). Lijnrecht daartegenover staan evenwel de resultaten van een recent onderzoek naar het Zweedse beleid van criminalisering van uitbating en gebruik van prostitutie (zie www. sweden.gov.se/sb/d/I3358/a/I4923I). 
Als het beoogde robuuste prostitutieregime wordt gehandhaafd en neerdaalt bij de spelers in de markt (exploitant, prostituee en klant), kan de aanpak van mensenhandel in de seksindustrie effectiever worden.

\subsection{Vreemdelingen}

Mensenhandel is verweven met illegaliteit. ${ }^{223}$ Aanpak van illegaliteit draagt bij aan de aanpak van mensenhandel en vice versa. ${ }^{224}$

De wetgeving inzake vreemdelingen voorziet in de aanpak van illegaliteit en in de bescherming van illegale slachtoffers van mensenhandel. Veel slachtoffers van mensenhandel zijn onderdanen van derde landen die in Nederland verblijven zonder geldige verblijfstitel. Op deze wetgeving is de zogenoemde B9-regeling gebaseerd. ${ }^{225}$ Deze regeling voorziet in een tijdelijke verblijfstitel voor slachtoffers en getuigen van mensenhandel die hun medewerking verlenen aan het strafproces (opsporing, vervolging en berechting). Dit verblijf kan na afloop van het proces worden voortgezet op humanitaire gronden. Deze vreemdelingen mogen gedurende hun geldig verblijf inkomsten uit arbeid verwerven. Daarmee wordt uitvoering gegeven aan de EG-richtlijn tijdelijke verblijfstitel. ${ }^{226}$

Mensensmokkel is hulp bij illegale binnenkomst. Mensensmokkel is anders dan mensenhandel niet (primair) gericht op uitbuiting. Bij mensensmokkel is allereerst het belang van een staat in het geding: dat op het grondgebied van die staat alleen mensen verblijven die daartoe zijn gerechtigd. ${ }^{227}$ Mensenhandel en mensensmokkel worden nog wel eens met elkaar verward. Zij gaan vaak hand in hand. Mensensmokkel faciliteert en genereert mensenhandel. Niet zelden worden mensenhandel en mensensmokkel tezamen ten laste gelegd.

Artikel I97a Sr stelt mensensmokkel en hulp bij illegaal verblijf strafbaar. Artikel 197b Sr stelt strafbaar degene die een vreemdeling krachtens overeenkomst of

223 Zie illegalennota, Kamerstukken 2003/04, 29 537, nr. 2, p. 5: 'Onrechtmatig verblijf heeft tot gevolg dat betrokkenen een zwakke sociaal economische en maatschappelijke kwetsbare positie hebben. Deze kwetsbaarheid kan leiden tot uitbuiting en kan, zoals hierboven betoogd, mensen verleiden tot deelname aan onwettige of criminele activiteiten. De genoemde zwakke sociaaleconomische positie van genoemde groep mensen zorgt er onder meer voor dat zij bereid zijn tegen een geringe beloning op de arbeidsmarkt actief te zijn, dat zij veelal geen belasting (kunnen) afdragen, dat zij bereid zijn onder slechte omstandigheden gehuisvest te zijn, dat zij gevoelig zijn voor uitbuiting zoals gedwongen prostitutie. Maar het betekent ook dat deze mensen vaak hun toevlucht nemen tot illegale sectoren van de samenleving zoals bijvoorbeeld drugshandel.'

224 Illegalennota, a.w. p. 9: 'Een adequate bestrijding van mensenhandel levert een belangrijke bijdrage aan de aanpak van illegaliteit. Met de strafrechtelijke aanpak van mensenhandel worden immers de parasitaire (infra)structuren achter de illegale immigratie aangepakt. Dat is ook de reden dat de aanpak van migratiecriminaliteit (waaronder grensoverschrijdende mensenhandel) steeds deel heeft uitgemaakt van de strategie voor de aanpak van illegale immigratie.'

225 Zie NRM 7, hoofdstuk 5.

226 Richtlijn 2004/8I/EG van de Raad van 29 april 2004 betreffende de verblijfstitel die wordt afgegeven aan onderdanen van derde landen die het slachtoffer zijn van mensenhandel of hulp hebben gekregen van bij illegale immigratie als ze meewerken met de bevoegde autoriteiten.

227 Zie J.J. Wiarda, 'Trends in de wetgeving inzake mensensmokkel en mensenhandel', TvC 200r/4, p. 368 . 
aanstelling arbeid doet verrichten, terwijl hij weet of ernstige reden heeft om te vermoeden dat die ander illegaal is.

Bij illegale tewerkstelling wordt nogal eens zwart gewerkt voor een subminimumloon. Dat levert de tewerksteller financieel voordeel op, benadeelt de schatkist en leidt tot concurrentievervalsing.

De Wet arbeid vreemdelingen (Wav) voorziet in de aanpak van illegale tewerkstelling. Daartoe bestaat een stelsel van tewerkstellingsvergunningen. De wet gaat uit van een zogenoemd prioriteitgenietend aanbod van Nederlandse werkzoekenden, in de EER ${ }^{228}$ werkzoekende vreemdelingen of daarmee gelijkgestelden die vrij zijn om arbeid te verrichten op de Nederlandse arbeidsmarkt. Zij hebben voorrang op die markt. Dit uitgangspunt is bepalend voor beantwoording van de vraag of aan de arbeid van een derdelander behoefte bestaat.

Dit uitgangspunt is niet bruikbaar in de seksindustrie. Daarom is de Wav niet geschikt voor de seksbranche. Ingevolge artikel 3 Besluit uitvoering Wet arbeid vreemdelingen is er een algeheel verbod voor tewerkstelling in de seksbranche. Aanvankelijk zou dit verbod tijdelijk zijn in afwachting van de resultaten van een zoektocht naar een werkend systeem voor beoordeling van de behoefte aan seksuele dienstverlening door een vreemdeling. Dan zou de Wav niet langer van toepassing zijn op de seksbranche. Dit systeem is niet gevonden. Bovendien rijpte het inzicht dat het niet op de weg van de overheid ligt om de immigratie van sekswerkers te faciliteren. Het verbod is daarom gehandhaafd. Het draagt bij aan de bestrijding van grensoverschrijdende mensenhandel. De Arbeidsinspectie is belast met de handhaving van de Wav. Overtreding van de Wav wordt aangepakt met een bestuurlijke boete en door middel van de Wet economische delicten.

In 2009 is de richtlijn sancties werkgever voor illegale tewerkstelling tot stand gekomen. ${ }^{229}$ Uitgangspunt is een verbod op illegale tewerkstelling voor onderdanen van derde landen. Er is een uitzondering voor vreemdelingen wier verwijdering is uitgesteld en die overeenkomstig national recht mogen werken. Inbreuken worden bestraft met sancties en maatregelen. Ernstige inbreuken moeten ook strafrechtelijk kunnen worden aangepakt. ${ }^{230}$ Een dergelijke verplichting tot strafbaarstelling schept geen verplichtingen met betrekking tot de toepassing van de strafrechtelijke sancties of een ander beschikbaar rechtshandhavinginstrument in individuele gevallen. ${ }^{231}$

228 De Europese Economische Ruimte. Die bestaat uit de EU, zonder Bulgarije en Roemenië, en met Noorwegen en IJsland.

229 Richtlijn 2009/52/EG van I8 juni 2009 tot vaststelling van minimumnormen inzake sancties en maatregelen tegen werkgevers van illegaal verblijvende onderdanen van derde landen.

230 Dat zijn ingevolge artikel 9 lid I: (a) inbreuk blijft doorgaan of wordt voortdurend herhaald, (b) inbreuk heeft betrekking op gelijktijdige tewerkstelling van een aanzienlijk aantal illegalen derde landers, (c) inbreuk wordt begaan door werkgever die weliswaar niet is beschuldigd of is veroordeeld voor een overtreding van het EU-kaderbesluit mensenhandel, maar die werk of diensten laat verrichten door een illegale derdelander in de wetenschap dat deze slachtoffer van mensenhandel is, of (d) inbreuk betreft illegale tewerkstelling van een minderjarige.

23I Zie overweging 22 van de preambule van de richtlijn. 


\subsection{Arbeid}

Een werkgever is verplicht zich als een goed werkgever te gedragen (artikel 7:6II BW). Wat de seksindustrie betreft willen uitbaters en sekswerkers hun relatie liever niet vormgeven in een arbeidsovereenkomst. De Belastingdienst, de uitvoeringsinstanties van de sociale zekerheid en de Arbeidsinspectie gaan uit van een brede uitleg van de relatie werkgever/werknemer. De tewerksteller heeft de keuze tussen tewerkstelling in loondienst of een hybride voorwaardenpakket. In dit pakket doet de exploitant de noodzakelijke afdrachten en heeft de sekswerker een zelfstandige positie.

De Arbeidstijdenwet, de Arbeidsomstandighedenwet en de Wet minimumloon en minimumvakantietoeslag en de op die wetten gebaseerde uitvoeringswetgeving voorzien in regels met betrekking tot toelaatbare arbeid, fatsoenlijke honorering, fatsoenlijke arbeidsvoorwaarden en -omstandigheden voor volwassen en jeugdige deelnemers aan de arbeidsmarkt.

Malafide uitzendbureaus en inleners kunnen zich schuldig maken aan mensenhandel dan wel deze bevorderen. ${ }^{232}$ Ingevolge de Wet allocatie arbeidskrachten door intermediairs is de inlener aansprakelijk voor de juiste afdracht van belastingen en premies voor personeel dat is ingeleend bij een uitzendbureau. Er is wetgeving in voorbereiding die voorziet in aansprakelijkheid van de inlener voor de betaling van minimumloon en minimumvakantiebijslag.

\subsection{Wonen}

De twee belangrijkste overlevingsstrategieën van illegalen in Nederland zijn gericht op het verkrijgen van werk en het verwerven van onderdak.

De Woningwet en de Huisvestingswet scheppen condities voor fatsoenlijke bewoning en huisvesting. Op basis van deze wetgeving en op de grondslag van artikel r97a lid 2 Sr (uit winstbejag hulp bieden bij verblijf van illegalen) kan tegen zogenoemde huisjesmelkers worden opgetreden. Huisjesmelkers faciliteren mensenhandel. De Woningwet, de Huisvestingswet en de Gemeentewet zijn onlangs aangescherpt met de invoering van een bestuurlijke boete en ruimere mogelijkheden tot sluiting van een woning met het oog op een betere aanpak van illegale doorverhuur, overbewoning, illegale pensions en beddenverhuur, en onrechtmatig gebruik van een woning voor hennepteelt, prostitutie en drugshandel.

232 NRM 7, hoofdstuk I2.5.I over malafide uitzendbureaus en de brief van de minister van Sociale Zaken en Werkgelegenheid van I4 augustus 2007 over malafide inleners, Kamerstukken II 2006/07, 29 407, nr. 73. 


\subsection{Organen}

De Wet op orgaandonatie beoogt het aanbod en een rechtvaardige verdeling van geschikte organen te bevorderen en de handel in organen te voorkomen. ${ }^{233}$ Onrechtmatige orgaanverwijdering en orgaanhandel komen in Nederland niet of nauwelijks voor. Dat wil niet zeggen dat Nederlanders niet betrokken (kunnen) zijn bij onrechtmatige orgaanverwijdering elders. Onrechtmatige orgaanverwijdering en orgaanhandel zijn een gevolg van een tekort aan organen.

Artikel 32 Wet op de orgaandonatie stelt onder meer als misdrijf strafbaar: het opzettelijk teweegbrengen of bevorderen dat een ander aan een derde toestemming verleent voor orgaanverwijdering tijdens leven tegen een commerciële vergoeding, het openlijk aanbieden van een commerciële vergoeding voor een orgaan dan wel het zich aanbieden als donor tegen een dergelijke vergoeding.

\section{$7 \quad$ Conclusie}

Onze verkenning is een boeiende geweest. Wetgevingsambtenaren krijgen niet altijd de gelegenheid zich in het kader van een wetenschappelijke studie zo intensief te bemoeien met wetgeving waaraan zij werken of hebben gewerkt. Onze reis over het terrein waarop mensenhandel en de aanpak ervan zich afspelen, heeft nieuwe gezichtspunten en soms nieuwe inzichten opgeleverd.

Als we de afgelopen decennia overzien, dan constateren we dat de strafwetgeving inzake mensenhandel - nationaal en internationaal - steeds strenger is geworden. Het bereik is sterk toegenomen en de maximumstraffen zijn steeds hoger geworden. Het einde is nog niet in zicht.

Tegenover deze verdergaande 'criminalisering' van moderne vormen van slavernij staat de legalisering van de prostitutiesector. Legalisering zonder nadere bestuurlijke regulering heeft niet geleid tot een effectief prostitutiebeleid. De voorgestelde nieuwe prostitutiewetgeving beoogt de legale sector beter te ordenen en gezonder te maken en daarmee bij te dragen aan de aanpak van uitbuiting in de seksindustrie. Dat kan lukken, als de handhaving op orde is en de markt zich voegt naar de nieuwe ordening.

Misstanden komen ook voor in andere sectoren dan de seksindustrie. Daarmee werd de uitbreiding van mensenhandel tot overige uitbuiting noodzakelijk. De strafbaarstelling van overige uitbuiting heeft het misdrijf wel complexer en weerbarstiger gemaakt. Daarom moet het bewustzijn (van de condities) voor overige uitbuiting worden verhoogd, in de gehele samenleving, bij uitbaters, potentiële slachtoffers, klanten en personen die met de handhaving zijn belast of werken in de rechtspraktijk.

233 Zie NRM 7, hoofdstuk 13. 
Aan het eind gekomen ordenen we de uitkomsten van onze ontdekkingsreis in een aantal conclusies.

I. Het verschijnsel mensenhandel heeft vele facetten. Dat geldt ook voor de internationale en nationale aanpak ervan. Die aanpak is alomvattend, en speelt zich af op de terreinen van preventie, bestrijding, internationale (strafrechtelijke) samenwerking en bijstand aan slachtoffers en hun familie. Hierbij werken overheden en niet-overheden samen. De strafrechtelijke bestrijding van mensenhandel is een bescheiden, gewichtig en noodzakelijk sluitstuk in die aanpak.

2. Artikel $273 \mathrm{f} \mathrm{Sr}$ voorziet in een ruimere strafrechtelijke bescherming van slachtoffers van mensenhandel dan de bescherming waarin internationale instrumenten voorzien waaraan Nederland is gebonden.

3. Uit artikel $273 \mathrm{f} \mathrm{Sr}$, zijn wetsgeschiedenis en de daaraan ten grondslagliggende internationale instrumenten kan niet worden afgeleid dat de vraag of in een mensenhandelzaak fundamentele mensenrechten zijn geschonden, afzonderlijke en zelfstandige beantwoording behoeft. Als de bestanddelen van de in artikel $273 \mathrm{f}$ Sr omschreven strafbare feiten aanwezig zijn/kunnen worden bewezen, is er sprake van mensenhandel. Daarmee is een schending van mensenrechten gegeven. Alle in artikel $273 \mathrm{f}$ Sr strafbaar gestelde gedragingen leveren een schending van mensenrechten op.

4. $\mathrm{Nu}$ de definitie van uitbuiting in artikel $273 \mathrm{flid} 2 \mathrm{Sr}$ is ontleend aan internationale instrumenten, kleurt de internationale rechtspraak met betrekking tot de in die definitie omschreven vormen van uitbuiting, de delictsomschrijving. Het internationale recht werkt door in de nationale rechtspraktijk.

5. De rechtspraak inzake mensenhandel gaat uit van een ruimhartige strafrechtelijke beschermingsomvang ten aanzien van slachtoffers van mensenhandel. Dat past in de visie van de Hoge Raad op strafwetgeving die personen beoogt te beschermen tegen aantasting van hun lichamelijke en geestelijke integriteit.

6. Voor de beantwoording van de vraag of er sprake is van ongeoorloofde beïnvloeding van slachtoffers, van een uitbuitingssituatie en van (het oogmerk van) overige uitbuiting zijn ook de wetsgeschiedenis en de rechtspraak over de voorlopers van artikel $273 \mathrm{f} \mathrm{Sr}$, die gericht waren op bestrijding van uitbuiting in de prostitutie en in de overige seksuele dienstverlening, relevant.

7. Er is geen principieel onderscheid tussen mensenhandel in de seksuele dienstverlening en die in de overige dienstverlening. De aard van de werkzaamheden is wel mede van belang voor de vraag of er sprake is van uitbuiting en de straftoemeting.

8. Artikel $273 \mathrm{f} \mathrm{Sr}$ richt zich wat de overige uitbuiting betreft niet slechts op excessen daarin. Het is een misverstand dat alleen bij excessen in uitbating sprake is van 
schending van fundamentele mensenrechten. Voor terughoudendheid bij de beoordeling van de vraag of er sprake is van mensenhandel/uitbuiting is geen aanleiding. Iets anders is dat het $\mathrm{OM}$ in zijn vervolgingsbeleid ten aanzien van overige uitbuiting prioriteit kan verlenen aan excessen daarin.

9. Bij de beoordeling of er sprake is van mensenhandel wordt gekeken naar vier met elkaar samenhangende elementen: (I) het handelen van de dader (met gebruik van ongeoorloofde middelen een handeling ten opzichte van het slachtoffer verrichten met het oog op diens uitbuiting - mensenhandel in eigenlijke zin - dan wel met gebruik van die middelen het slachtoffer brengen tot of houden in het zich beschikbaar stellen tot het verrichten van arbeid of diensten - het eigenlijke uitbuiten), (2) de (kwetsbare) situatie waarin het slachtoffer verkeert (uitbuitingssituatie), (3) de aard van de door het slachtoffer te verrichten arbeid of diensten en (4) de omstandigheden waaronder die (zullen) worden verricht. De elementen 3 en 4 kunnen nadere inhoud aan de uitbuitingssituatie geven. Soms wordt het gebruik van specifieke ongeoorloofde middelen (misbruik van overwicht of van een zwakke positie) verondersteld in een uitbuitingssituatie. Onvrijwilligheid en arbeid tezamen (in een uitbuitingssituatie) vormen uitbuiting.

Io. De wetgever heeft in het kader van de (beoogde) opheffing van het bordeelverbod de strafrechtelijke bescherming van kwetsbare slachtoffers van mensenhandel aanzienlijk verruimd. Het begrip uitbuitingssituatie is daarbij door de wetgever als objectief ijkpunt geïntroduceerd.

II. Een persoon bevindt zich in een uitbuitingssituatie wanneer hij niet of slechts in mindere mate de mogelijkheid heeft een vrije keuze te maken met betrekking tot het aangaan of voortzetten van een relatie met de tewerksteller. Een uitbuitingssituatie wordt onder meer verondersteld in geval van illegaal verblijf, het niet kunnen beschikken over eigen financiële middelen of over een reisdocument en het verlopen van een paspoort.

I2. Voor het bewijs van de bestanddelen 'misbruik van uit feitelijke omstandigheden voortvloeiend overwicht' en 'misbruik van een kwetsbare positie' vindt objectivering plaats. Voor het bewijs van dat misbruik is voldoende dat de dader zich bewust is van de relevante feitelijke omstandigheden van de betrokkene waaruit het overwicht of een kwetsbare positie voortvloeit of verondersteld wordt voort te vloeien. De aanwezigheid van voorwaardelijk opzet ten aanzien van die omstandigheden bij de dader is dus toereikend.

I3. De vraag of - en zo ja, wanneer - sprake is van 'uitbuiting' in de zin van artikel $273 \mathrm{f} \mathrm{Sr}$ is niet in algemene termen te beantwoorden, maar is sterk verweven met de omstandigheden van het geval. Daarbij komt (bij overige uitbuiting) onder meer betekenis toe aan de aard en duur van de tewerkstelling, de beperkingen die zij voor de betrokkene meebrengt, en het economische voordeel dat daarmee door de tewerksteller wordt behaald. Bij de weging van deze en andere relevante factoren 
dienen de in de Nederlandse samenleving geldende maatstaven als referentiekader te worden gehanteerd.

I4. Bij de weging van de voor uitbuiting buiten Nederland relevante factoren gelden de in de Nederlandse samenleving geldende maatstaven in beginsel als referentiekader. Bij deze weging dienen ook de maatstaven te worden betrokken die gelden in het land waar het feit is gepleegd.

I5. Aard en strekking van de strafbaarstelling van mensenhandel moeten worden betrokken bij de vaststelling van de eisen die aan het bewijs voor het oogmerk van uitbuiting worden gesteld. Voldoende is dat de dader weet of het althans mogelijk acht dat zijn handelen verband houdt met uitbuiting. Daarbij is niet nodig om een keuze te maken uit een van de vormen van uitbuiting, bedoeld in artikel $273 \mathrm{f} \mathrm{lid} 2$ Sr. Voldoende is dat de wezenskenmerken van een van die vormen van uitbuiting aanwezig zijn of mogen worden verondersteld.

I6. Het is verstandig dat de wetgever bij een goede gelegenheid alsnog een nadere uiteenzetting geeft over de bepaling in internationale instrumenten dat instemming van het slachtoffer met de beoogde of daadwerkelijke uitbuiting niet relevant is, als er sprake is van ongeoorloofde beïnvloeding. Hij is dan tevens in de gelegenheid om mede aan de hand van de stand van de ontwikkeling van de rechtspraak in te gaan op het onderscheid tussen het gebruik van ongeoorloofde middelen (misbruik) en het gebruik van geoorloofde middelen, tussen (ongeoorloofde) uitbuiting en (geoorloofde) uitbating.

I7. De wetgever moet 'dienstbaarheid' als zelfstandige vorm van uitbuiting alsnog opnemen in artikel $273 \mathrm{flid} 2 \mathrm{Sr}$.

I8. Het lijkt onontkoombaar dat de strafwetgeving inzake mensenhandel telkenmale aanpassing behoeft in verband met in het bijzonder internationale ontwikkelingen.

Onze slotconclusie kan kort zijn: artikel $273 \mathrm{f}$ Sr geeft de rechtspraktijk vooralsnog voldoende mogelijkheden voor een effectieve strafrechtelijke aanpak van mensenhandel in al zijn vormen in en buiten Nederland. 


\section{Bijlage I: Strafbepalingen}

\section{Artikel $273 \mathrm{fSr}$}

I. Als schuldig aan mensenhandel wordt met gevangenisstraf van ten hoogste acht jaren of geldboete van de vijfde categorie gestraft:

$I^{\circ}$. degene die een ander door dwang, geweld of een andere feitelijkheid of door dreiging met geweld of een andere feitelijkheid, door afpersing, fraude, misleiding dan wel door misbruik van uit feitelijke omstandigheden voortvloeiend overwicht, door misbruik van een kwetsbare positie of door het geven of ontvangen van betalingen of voordelen om de instemming van een persoon te verkrijgen die zeggenschap over die ander heeft, werft, vervoert, overbrengt, huisvest of opneemt, met het oogmerk van uitbuiting van die ander of de verwijdering van diens organen;

$2^{\circ}$. degene die een ander werft, vervoert, overbrengt, huisvest of opneemt, met het oogmerk van uitbuiting van die ander of de verwijdering van diens organen, terwijl die ander de leeftijd van achttien jaren nog niet heeft bereikt;

$3^{\circ}$. degene die een ander aanwerft, medeneemt of ontvoert met het oogmerk die ander in een ander land ertoe te bewegen zich beschikbaar te stellen tot het verrichten van seksuele handelingen met of voor een derde tegen betaling;

$4^{\circ}$. degene die een ander met een van de onder $I^{\circ}$ genoemde middelen dwingt of beweegt zich beschikbaar te stellen tot het verrichten van arbeid of diensten of zijn organen beschikbaar te stellen dan wel onder de onder $\mathrm{I}^{\circ}$ genoemde omstandigheden enige handeling onderneemt waarvan hij weet of redelijkerwijs moet vermoeden dat die ander zich daardoor beschikbaar stelt tot het verrichten van arbeid of diensten of zijn organen beschikbaar stelt;

$5^{\circ}$. degene die een ander ertoe brengt zich beschikbaar te stellen tot het verrichten van seksuele handelingen met of voor een derde tegen betaling of zijn organen tegen betaling beschikbaar te stellen dan wel ten aanzien van een ander enige handeling onderneemt waarvan hij weet of redelijkerwijs moet vermoeden dat die ander zich daardoor beschikbaar stelt tot het verrichten van die handelingen of zijn organen tegen betaling beschikbaar stelt, terwijl die ander de leeftijd van achttien jaren nog niet heeft bereikt;

$6^{\circ}$. degene die opzettelijk voordeel trekt uit de uitbuiting van een ander;

$7^{\circ}$. degene die opzettelijk voordeel trekt uit de verwijdering van organen van een ander, terwijl hij weet of redelijkerwijs moet vermoeden dat diens organen onder de onder $\mathrm{I}^{\circ}$ bedoelde omstandigheden zijn verwijderd;

$8^{\circ}$. degene die opzettelijk voordeel trekt uit seksuele handelingen van een ander met of voor een derde tegen betaling of de verwijdering van diens organen tegen betaling, terwijl die ander de leeftijd van achttien jaren nog niet heeft bereikt;

$9^{\circ}$. degene die een ander met een van de onder $\mathrm{I}^{\circ}$ genoemde middelen dwingt dan wel beweegt hem te bevoordelen uit de opbrengst van diens seksuele handelingen met of voor een derde of van de verwijdering van diens organen. 
2. Uitbuiting omvat ten minste uitbuiting van een ander in de prostitutie, andere vormen van seksuele uitbuiting, gedwongen of verplichte arbeid of diensten, slavernij en met slavernij of dienstbaarheid te vergelijken praktijken.

3. De schuldige wordt gestraft met gevangenisstraf van ten hoogste twaalf jaren of geldboete van de vijfde categorie, indien:

$I^{\circ}$. de feiten, omschreven in het eerste lid, worden gepleegd door twee of meer verenigde personen;

$2^{\circ}$. de persoon ten aanzien van wie de in het eerste lid omschreven feiten worden gepleegd, de leeftijd van zestien jaren nog niet heeft bereikt.

4. Indien een van de in het eerste lid omschreven feiten zwaar lichamelijk letsel ten gevolge heeft of daarvan levensgevaar voor een ander te duchten is, wordt gevangenisstraf van ten hoogste vijftien jaren of geldboete van de vijfde categorie opgelegd.

5. Indien een van de in het eerste lid omschreven feiten de dood ten gevolge heeft, wordt gevangenisstraf van ten hoogste achttien jaren of geldboete van de vijfde categorie opgelegd.

6. Artikel $25 \mathrm{I}$ is van overeenkomstige toepassing.

\section{Artikel 250a (oud) Sr}

I. Met gevangenisstraf van ten hoogste zes jaren of geldboete van de vijfde categorie wordt gestraft:

$I^{\circ}$. degene die een ander door geweld of een andere feitelijkheid of door bedreiging met geweld of een andere feitelijkheid dwingt dan wel door misbruik van uit feitelijke verhoudingen voortvloeiend overwicht of door misleiding beweegt zich beschikbaar te stellen tot het verrichten van seksuele handelingen met een derde tegen betaling, dan wel onder voornoemde omstandigheden enige handeling onderneemt waarvan hij of zij weet of redelijkerwijs moet vermoeden dat die ander zich daardoor tot het verrichten van die handelingen beschikbaar stelt;

$2^{\circ}$. degene die een persoon aanwerft, medeneemt of ontvoert met het oogmerk die persoon in een ander land ertoe te brengen zich beschikbaar te stellen tot het verrichten van seksuele handelingen met een derde tegen betaling;

$3^{\circ}$. degene die een ander ertoe brengt zich beschikbaar te stellen tot het verrichten van seksuele handelingen met een derde tegen betaling, dan wel ten aanzien van een ander enige handeling onderneemt waarvan hij of zij weet of redelijkerwijs moet vermoeden dat die ander zich daardoor tot het verrichten van die handelingen beschikbaar stelt, terwijl die ander minderjarig is;

$4^{\circ}$. degene die opzettelijk voordeel trekt uit seksuele handelingen van een ander met een derde tegen betaling, terwijl hij weet of redelijkerwijs moet vermoeden dat die ander zich onder de onder $\mathrm{I}^{\circ}$ genoemde omstandigheden beschikbaar stelt tot het plegen van die handelingen;

$5^{\circ}$. degene die opzettelijk voordeel trekt uit seksuele handelingen van een ander met een derde tegen betaling, indien die ander minderjarig is;

$6^{\circ}$. degene die een ander door geweld of een andere feitelijkheid of door bedreiging met geweld of een andere feitelijkheid dwingt dan wel door misbruik van uit feitelijke verhoudingen voortvloeiend overwicht of door misleiding beweegt hem of 
haar uit de opbrengst van zijn of haar seksuele handelingen met een derde te bevoordelen.

2. De schuldige wordt gestraft met een gevangenisstraf van ten hoogste acht jaren of geldboete van de vijfde categorie, indien:

$I^{\circ}$. de feiten, omschreven in het eerste lid, worden gepleegd door twee of meer verenigde personen;

$2^{\circ}$. de minderjarige de leeftijd van zestien jaren nog niet heeft bereikt;

$3^{\circ}$. geweld of een andere feitelijkheid als bedoeld in het eerste lid zwaar lichamelijk letsel ten gevolge heeft.

3. De feiten, omschreven in het eerste lid, gepleegd door twee of meer verenigde personen onder de omstandigheden, bedoeld in het tweede lid, onder $2^{\circ}$ en $3^{\circ}$, worden gestraft met gevangenisstraf van ten hoogste tien jaren of geldboete van de vijfde categorie. 



\section{Bijlage 2: Uit de Aanwijzing mensenhandel (Stcrt. 2008, 2718)}

\section{Lijst met indicatoren / kenmerken van mensenhandel}

De volgende factoren en bevindingen uit onderzoek kunnen een rol spelen bij het signaleren in de opsporing dat mensenhandel aan de orde is. Het betreft een nietlimitatieve opsomming van voorbeelden die vanzelfsprekend niet allemaal tegelijk op hoeven te gaan.

\section{Meervoudige afhankelijkheid}

ra. De werkgever/exploitant regelt ook huisvesting, kleding, vervoer

- niet zelf de reis, visa, enz. hebben geregeld

- beschikken over een vals of vervalst paspoort

- illegaal verblijvend/werkend in Nederland

- angst voor bijvoorbeeld uitzetting, mishandeling enz.

- ontbreken van eigen woonruimte in Nederland

- overnachten op de werkplek

- onbekendheid met het eigen werkadres

- in sociaal isolement gebracht door werkgever of exploitant

Ib. Het slachtoffer heeft schulden

- er is sprake van schuldopbouw bij derden (bijvoorbeeld exploitant of souteneur)

- de exploitant of souteneur heeft een overnamebedrag betaald

2. Een sterke inperking van de basisvrijheden van de betrokkene

2a. Het slachtoffer kan of mag geen contact hebben met de buitenwereld

- het onthouden van medische hulp

- slachtoffer heeft geen zelfstandige bewegingsvrijheid

2b. Het slachtoffer heeft geen beschikking over eigen identiteitspapieren

2c. Het slachtoffer heeft geen beschikking over de eigen verdiensten

- niet vrijelijk kunnen beschikken over de eigen verdiensten

- onredelijk hoge afdracht van de inkomsten (onredelijk naar tijd en plaats beoordeeld)

3. Het werken of verlenen van diensten onder zeer slechte omstandigheden

- het slachtoffer ontvangt een ongebruikelijk laag loon in vergelijking met de markt

- het slachtoffer werkt onder gevaarlijke omstandigheden

- het slachtoffer maakt uitzonderlijk lange werkdagen of werkweken

- onder alle omstandigheden en buitenproportioneel lang werken

- chantage of bedreiging van familie

- er is sprake van mensensmokkel van alleenstaande vrouwen

- de combinatie: niet EU, huwelijk of verblijf bij partner en kort nadien werken in de prostitutie 
- relatie met personen met relevante antecedenten of locaties die geassocieerd worden met mensenhandel

- is afkomstig uit een bronland

- verplichting om een minimum bedrag per dag te verdienen

- slaafse houding ten opzichte van exploitant of souteneur

- gebouwen met camera's (ook intern); schuilplaatsen, fake-inrichting, bodyguards enz.

4. Aantasting van de lichamelijke integriteit van de betrokkene

- het afstaan van organen

- onvrijwillig tewerkgesteld in de prostitutie

- bedreigd of geconfronteerd met geweld

- dreiging met of daadwerkelijke toepassing van geweld, het dragen van sporen van lichamelijke mishandeling

- kenmerken die duiden op afhankelijkheid van de exploitant/souteneur (bijvoorbeeld tatoeages of voodoomateriaal)

- onder dwang (bepaalde) seksuele handelingen moeten verrichten

5. De uitbuiting is niet incidenteel, maar er is sprake van een patroon of een in enigerlei mate georganiseerd verband

- tips van betrouwbaar geachte bekende derden (gewicht afhankelijk van informatie)

- het afwisselend op verschillende plaatsen werken 